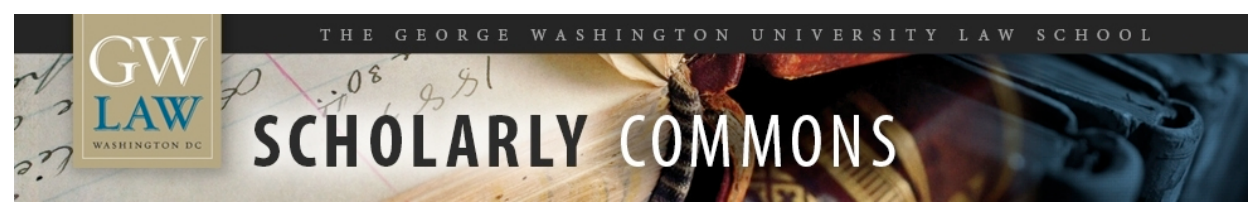

\title{
But Some are More Equal: Race, Exclusion, and Campaign Finance
}

Spencer A. Overton

George Washington University Law School, soverton@law.gwu.edu

Follow this and additional works at: https://scholarship.law.gwu.edu/faculty_publications

Part of the Law Commons

\section{Recommended Citation}

Spencer Overton, But Some are More Equal: Race, Exclusion, and Campaign Finance, 80 Tex. L. Rev. 987 (2002).

This Article is brought to you for free and open access by the Faculty Scholarship at Scholarly Commons. It has been accepted for inclusion in GW Law Faculty Publications \& Other Works by an authorized administrator of Scholarly Commons. For more information, please contact spagel@law.gwu.edu. 


\title{
Texas Law Review
}

Volume 80, Number 5, April 2002

\author{
Articles
}

\section{But Some Are More Equal: Race, Exclusion, and Campaign Finance ${ }^{\dagger}$}

\section{Spencer Overton*}

\section{Introduction}

Legal academics who call for campaign finance reform-let us call them "Reformers" - have overlooked the significance of race, and as a result their critiques of constitutional jurisprudence and reform proposals remain woefully incomplete. Studies reveal that people of color comprise approximately thirty percent of the nation's population, ${ }^{1}$ but represent only about

\section{See GEORGE ORWELl, ANIMAL FARM 123 (1946).}

Acting Professor of Law, University of California, Davis. Houston Fellow, Harvard Law School, 1999-2000; J.D., Harvard Law School, 1993; B.A., Hampton University, 1990. A number of people read earlier versions or sections of this Article and provided helpful comments, including Diane Amann, Richard Banks, Derrick Bell, John Bonifaz, Paul Butler, Guy Charles, Roger Fairfax, Anthony Farley, Floyd Feeney, Edward Foley, Heather Gerken, Richard Hasen, Benjamin Highton, Bill Hing, Kevin Johnson, Tom Joo, Lewis LaRue, Ira C. Lupu, Kenneth Mack, Frank Michelman, Blake Morant, Melissa Nobles, Leslie Overton, Jamin Raskin, Jeff Selbin, Joseph Singer, Terry Smith, Kim Taylor-Thompson, Stephanie Wildman, Adrien Wing, Fane Wolfer, Brenda Wright, and students in my Fall 2001 Voting Rights course at U.C. Davis. This Article also benefited from my exchanges with Susan Anderson, Leonard Baynes, Carrie Bolton, William Bratton, Bruce Cain, Rafaela Castro, Devon Carbado, Anupam Chander, Richard Delgado, Sherry DuPont, Zanita Fenton, Gerald Frug, Paul Frymer, Lani Guinier, Angela Harris, Lynne Henderson, Pamela Karlan, Ellen Katz, Ian Haney Lopez, Kenneth Mack, Randall Merritt, William McNary, Gwen Patton, Richard Pildes, Jean Stefancic, Ronald Sullivan, Madhavi Sunder, Stephanie Wilson, and Tobias Wolff, and from the outstanding research assistance of Shelley Bryant, Russell Johnson, Sonali Sarkar, and Aimee Steele. I would also like to thank participants in faculty workshops at the George Washington University Law School, the University of California, Berkeley, Boalt Hall School of Law (sponsored by the Center for Social Justice) and the University of Maryland School of Law for their valuable observations and suggestions. This Article is dedicated to the memory of LaMaurice Gardner, a mentor, advisor, and friend.

1. See U.S. Bureau of the Census, Resident Population Estimates of the United States by SeX, Race, AND Hispanic ORigin: April 1, 1990 to July 1, 1999, WITH SHORTTerm Projection to November 1, 2000, at 1 (2000) [hereinafter Census Population 
one percent of those who make significant political contributions to federal campaigns. ${ }^{2}$ Issues of racial identity necessarily evoke questions of representation in the political process, and the qualitative nature of representation is in part a product of the laws and procedures that govern democracy. ${ }^{3}$ Commentators, courts, and legislatures have extensively analyzed other facially race-neutral procedures that have historically excluded people of color from the political process, such as at-large electoral districts, poll taxes, and literacy tests, ${ }^{4}$ and they are beginning to analyze contemporary devices such as punch-card ballots. ${ }^{5}$ Although the doctrines and regulations governing the funding of campaigns are no less significant in shaping the racial distribution of political influence, the interplay between race and campaign finance remains largely unexamined. ${ }^{6}$

ESTIMATES], available at http://www.census.gov/population/estimates/nation/intfile3-1.txt (indicating that as of November 1, 2000, African Americans made up 12.8\%, Hispanics 11.9\%, Asian Americans 4.1\%, and American Indians, Eskimos, and Aleuts $0.9 \%$ of the population of the United States).

2. See John Green et al., Individual Congressional Campaign Contributors: Wealthy, Conservative and Reform-Minded, Individual Donors and Campaign Finance, 1998 JOYCE FOUNDATION 13 (showing that, in a random survey of individuals who made reportable contributions (contributions of $\$ 200$ or more), less than $1 \%$ of contributors surveyed identified themselves as people of color, whereas $95 \%$ identified themselves as white).

3. See Samuel Issacharoff, Pamela S. Karlan \& Richard H. Pildes, The Law of DEMOCRACY: Legal STRUCTURE OF THE POLITICAL PROCESS 1, 2 (1998) (stating that "[t]he kind of democratic politics we have is always and inevitably itself a product of institutional forms and legal structures" which "limit and define the decisions available through democratic politics itself"); $c f$. DANiEl H. LOWENSTEIN, EleCtion LAw: CASES AND MATERIALS, at xix (1995) (arguing that "[w] hat distinguishes an outstanding legal professional from an ordinary one in the field of election law is the ability to understand the details of legal regulations as they affect and at least aspire to benefit the democratic political system"); Richard H. Pildes \& Elizabeth S. Anderson, Slinging Arrows at Democracy: Social Choice Theory, Value Pluralism, and Democratic Politics, 90 COLUM. L. REV. 2121, 2198 (1990) (observing that "[p]olitical institutions and decision procedures must create the conditions out of which . . . a political community can forge for itself a collective will" and "specify whose views will be counted in determining the collective will").

4. See, e.g., Gomillion v. Lightfoot, 364 U.S. 339, 341, 347 (1960) (invalidating municipal redistricting that fenced out of the city all but "four or five of its 400 Negro voters while not removing a single white voter or resident"); Harman v. Forssenius, 380 U.S. 528, 543 (1965) ("The Virginia poll tax was born of a desire to disenfranchise the Negro."); Roy W. Copeland, The Status of Minority Voting Rights: A Look at Section V Preclearance Protections and Recent Decisions Affecting Multi-Member Voting Districts, 28 How. L.J. 417, 418 (1985) (citing Justice Black's opinion in Louisiana v. United States, 380 U.S. 145, 151 (1965), which stated that "Louisiana's interpretation test, as written and as applied, was part of a successful plan to deprive Louisiana Negroes of their right to vote"); Virginia E. Hench, The Death of Voting Rights: The Legal Disenfranchisement of Minority Voters, 48 CASE W. RES. L. REV. 727, 735 (1998) ("By the early 1900 s, a majority of states with large populations of freedmen had adopted poll taxes that effectively eliminated many potential African-American voters from the polls.").

5. See, e.g., Spencer Overton, A Place at the Table: Bush v. Gore Through the Lens of Race, 29 FLA. ST. U. L. REV. 469 (2001) (using race as a lens to examine the decision to disregard thousands of imperfectly perforated punch-card ballots in Florida following the 2000 presidential election).

6. Four recent works regarding campaign finance, all of which primarily analyze policy issues related to legislative proposals rather than constitutional jurisprudence, should be noted. See Terry Smith, Race and Money in Politics, 79 N.C. L. REV. 1469 (2001) (examining the difference between the meaning of political equality for whites and for people of color, and explaining that 
This Article employs race to expose fundamental shortcomings of existing campaign finance jurisprudence and to promote the development of more comprehensive reforms. Current campaign finance jurisprudence and the critiques made by the Reformers are founded upon normative assumptions about democracy that ignore important historical and social realities related to race. Existing frameworks fail to acknowledge that past statemandated discrimination against racial minorities has shaped the current distribution of property, which in turn hinders the ability of many people of color to participate fully in a privately financed political system.

By using the First Amendment to undermine legislative restrictions on the use of political money, courts effectively enshrine the existing distribution of property as a baseline for political advantage. This situation is especially troubling because courts generally allow for legislative restrictions that redistribute advantages in the economic sphere, and voting rights doctrine often mandates racial inclusion and equality in the political sphere. ${ }^{7}$ In addition, class-based legislative reform proposals sometimes inadvertently thwart the interests of people of color. An exclusively class-based approach to reform is inadequate because race operates as a distinct political identity worthy of independent analysis in the campaign finance context. Racial minorities play an important political role in democracy that transcends their class interests. ${ }^{8}$ The Reformers' failure to examine race prevents them from fully identifying and rectifying the flaws in the current campaign finance

legislative reforms such as higher contribution limits and the continued use of soft money may be less inclusive of people of color); Samuel Issacharoff, Race and Campaign Finance Reform, 79 N.C. L. REV. 1523 (2001) (asserting that proposed reform legislation might hinder black political advancement); Daniel H. Lowenstein, Campaign Finance, Race, and Equality, 79 N.C. L. REV. 1535 (2001) (supporting an increase in hard money contribution limits in order to make it easier for politicians to raise campaign finance money, and asserting that this proposal advances good government for all citizens, regardless of race); Jason P. Conti, Note, The Forgotten Few: Campaign Finance Reform and Its Impact on Minority and Female Candidates, 22 B.C. THIRD WORLD L.J. 99 (2002) (arguing that legislative reforms such as banning soft money contributions, lowering PAC contribution limits, and raising hard money contribution limits hurt minority candidates, whereas public financing helps minority candidates). While the above commentators consider race in examining legislative proposals to reform campaign finance, this Article considers race in examining the constitutional doctrine affecting campaign finance. See infra Parts II-IV. Part V of this Article also addresses legislative reforms by explaining the divergence of the above commentators' opinions.

7. See infra subpart IV(A).

8. Cf. Jerome McCristal Culp, Jr., Colorblind Remedies and the Intersectionality of Oppression: Policy Arguments Masquerading as Moral Claims, 69 N.Y.U. L. REV. 163, 191 (1994) ("The race of the voters matters in North Carolina precisely because the black voters have voted consistently against the racial politics of North Carolina's Congressional Club and Republican Party.”); Lani Guinier, [E]racing Democracy: The Voting Rights Cases, 108 HARV. L. REV. 109, 130 (1994) (observing that "minority group representation ... has a political component" and that "[g]roup members may identify collectively along a common axis and organize to promote common interests in ways similar to other political associations"); Martha Minow, Not Only for Myself: Identity, Politics, and Law, 75 OR. L. REV. 647, 697 (1996) (asserting that "[i]dentity politics have been crucial and perhaps inevitable responses to perceived oppressions"). 
system, and thus subtracts from the utility of both their critiques of constitutional jurisprudence and their legislative reform proposals.

Though some assert that decisionmakers should not consider race in a "colorblind" society, such a consideration need not entail the employment of a "race card" that trumps all other matters and singularly insists on racespecific solutions. Instead, just as scholars and legal decisionmakers balance such concerns as individual rights, economic efficiency, and general welfare,$^{10}$ they can use race as one analytical tool in conjunction with other factors. A consideration of racial history and context allows scholars and legal decisionmakers to avoid the pitfalls of the "colorblind card," an ideological extreme that mechanically trumps historical considerations, removes relevant issues from the table, and silences discussion.

Part II of the Article reviews understandings about democracy that Reformers and supporters of current campaign finance jurisprudence tend to emphasize. In arriving at divergent conclusions about the definition of a well-functioning democracy, the groups prioritize dissimilar values and make different assumptions about the realities of politics.

Part III discusses relevant, but previously overlooked, political realities related to race. While the Reformers correctly observe that property is distributed unevenly, they do not acknowledge that this uneven distribution arises in part from illegitimate factors such as past state-sponsored racial discrimination, or that racial disparities in property distribution are reflected in political participation in the current campaign finance system.

Part IV broadens the reform perspective to consider these racial realities in the political-money context. This expanded analysis allows for two fresh critiques that reveal how seemingly neutral campaign finance doctrine contributes to current racial disparities in political access and leads to future racial disparities in the political distribution of societal resources.

Recognizing that the U.S. Supreme Court's constitutional jurisprudence is only a part of the problem, Part V explores how political decisionmakers should consider race in analyzing legislative reforms. Individuals can harbor conflicting opinions about the racial impact of a single reform. These varied outlooks stem from different empirical and normative assumptions about the importance of various objectives that sometimes conflict, such as the political mobilization of voters of color, the accountability of political officials and parties to people of color, and the election of people of color to political

9. See City of Richmond v. J.A. Croson Co., 488 U.S. 469, 521 (1989) (Scalia, J., concurring) (arguing that "our Constitution is color-blind"). But see Regents of Univ. of Cal. v. Bakke, 438 U.S. 265, 336 (1978) (Brennan, White, Marshall, and Blackmun, JJ., dissenting in part and concurring in part) (noting that "no decision of this Court has ever adopted the proposition that the Constitution must be colorblind").

10. See Joseph William Singer, Property Law: Rules, Policies, ANd Practices 279-82 (1997) (describing the use of various policy considerations as analytical tools in lawmaking). 
office. A sophisticated policy analysis requires a judgment as to the relative importance of each objective, and an understanding of the extent to which a single legislative proposal furthers particular objectives and hinders other objectives.

\section{Existing Democratic Understandings Regarding Campaign Finance}

Some commentators have observed that judicial rulings on disputes regarding the law of the political process are influenced by judges' differing assumptions about how democracy works or should work. ${ }^{11}$ Likewise, those who argue for changes in the laws that govern campaign finance and those who defend the status quo rely on differing visions of politics that are all descriptively and normatively contestable. ${ }^{12}$ Decisions about campaign finance depend on decisionmakers' thoughts about whether a wellfunctioning democracy relies on integrity, widespread participation and input, reasoned deliberation, prevention of entrenchment, exchange unfettered by government, or other characteristics. ${ }^{13}$ Campaign finance decisions are also influenced by empirical assumptions and historical interpretations used by decisionmakers to determine how the characteristics listed above should be realized in a particular cultural context. ${ }^{14}$ These different

11. See Frank I. Michelman, Conceptions of Democracy in American Constitutional Argument: Voting Rights, 41 FLA. L. REV. 443, 444 (1989) (observing that with regard to "issues soaked with political interest... legal argument and judicial explanation ... unselfconsciously reflect underlying assumptions about actual and potential social relations, and about the institutional arrangements and forms of political life fit for those relations as they are and are capable of becoming"); $c f$. Spencer Overton, Rules, Standards, and Recounts: Form and the Law of Democracy, 37 HARV. C.R.-C.L. L. REV. 65 (2002) (observing that one's assumptions about democracy shape one's preference for using rules or standards to allocate discretion in the regulation of politics).

12. See, e.g., Samuel Issacharoff \& Pamela S. Karlan, The Hydraulics of Campaign Finance Reform, 77 TEXAS L. REV. 1705, 1708 (1999) (contending that "once the case for reform is understood to rest on a descriptively and normatively contestable vision of politics, we will be in a better position to discuss both the attractiveness of particular proposals for reform and the limits of a reform strategy"); William P. Marshall, The Last Best Chance for Campaign Finance Reform, 94 Nw. U. L. REV. 335, 376 (2000) (finding that "[d]emocracy does not have an ideal archetype" and thus "the case for [campaign finance] reform must be tempered by the awareness that there is no clear guidepost from which to evaluate whether democracy is, or is not, working").

13. See Michelman, supra note 11, at 444 (observing that disagreements in political cases often depend on different "normative conception[s] of democratic politics"); Mark Rush, The Law of Democracy, 5 LAW \& POL. BoOK REV. 239, 244 (1998) (stating that "the controversies that inhere in electoral process case law really have everything to do with the conflicting strains of democratic theory and, in reality, little to do with the inconsistencies of jurisprudence"); $c f$. Baker v. Carr, 369 U.S. 186, 300 (1962) (Frankfurter, J., dissenting) (arguing that the apportionment case required the court to "choose among competing bases of representation-ultimately, really, among competing theories of political philosophy - in order to establish an appropriate frame of government").

14. Cf. Richard H. Pildes, Democracy and Disorder, 68 U. CHI. L. REv. 695, 696 (2001) (describing judicial culture as "the empirical assumptions, historical interpretations, and normative ideals of democracy that seem to inform and influence the current constitutional law of democracy"). 
approaches to campaign finance are not necessarily more democratic or less democratic, but address and prioritize different concerns, values, and experiences. The approaches therefore provide for democracy and expression by employing different characteristics and qualities. ${ }^{15}$ In other words, the debate about campaign finance is not a simple choice about where to draw the line between individual expression and democracy. Instead, campaign finance involves substantive choices about the character, quality, and meaning of democracy, as well as similar choices about individual expression and other instruments used in securing one's definition of a wellfunctioning democracy. ${ }^{16}$ This Part reviews the distinct values and realities that Reformers, critics of Reformers, and supporters of current campaign finance jurisprudence emphasize.

\section{A. Democratic Understandings of Current Campaign Finance Jurisprudence}

In Buckley v. Valeo, ${ }^{17}$ the United States Supreme Court relied on its understanding about the importance of money in modern elections to derail attempts to restrict political spending. Buckley involved a challenge to contribution and spending limitations contained in the Federal Election Campaign Act Amendments of 1974 (the "1974 Act"), ${ }^{18}$ which, among other things, prohibited individuals from contributing more than $\$ 1000$ to a candidate for federal office. ${ }^{19}$ The 1974 Act also contained an array of expenditure limitations, including provisions that limited the amounts that

15. Cf. David A. Strauss, What Is the Goal of Campaign Finance Reform?, 1995 U. CHI. LEGAL F. 141, 141-42 (asserting that the varied arguments in favor of reform "in fact reflect unease about the underlying tensions in democratic theory - for example, concern that representatives are too responsive to their constituents, or concern that groups with greater access to resources have undue influence").

16. Cf. James A. Gardner, Liberty, Community and the Constitutional Structure of Political Influence: A Reconsideration of the Right to Vote, 145 U. PA. L. REV. 893, 897 (1997) (stating that “[w]e can hardly expect to figure out what voting - or 'fair' voting, or 'meaningful' voting — means without some conception of what voting is for, what purpose it serves within a larger regime of democratic self-government"); Marshall, supra note 12, at 375-76 (observing that the various goals of campaign finance reform often conflict and that the "fact that the types of harms to the political process are so varied means that there is little likelihood that a solution could be crafted that addresses all these concerns"); Bradley A. Smith, Faulty Assumptions and Undemocratic Consequences of Campaign Finance Reform, 105 YALE L.J. 1049, 1051 (1996) (complaining that "reform efforts are based on faulty assumptions" about how the reformist believes democracy works, and therefore reform proposals "inherently favor certain political elites, support the status quo, and discourage grassroots political activity").

17. 424 U.S. 1 (1976).

18. Federal Election Campaign Act Amendments of 1974, Pub. L. No. 93-443, 88 Stat. 1263 (repealed 1976).

19. Specifically, the 1974 Act prohibited an individual from giving more than $\$ 1000$ to a particular candidate per election, see 18 U.S.C. §608(b)(1) (Supp. IV 1974) (modified 1976, recodified at 2 U.S.C. $\$ 441 \mathrm{a}(\mathrm{a})(1)(\mathrm{A})$ ), and limited an individual's overall contributions to $\$ 25,000$ per year, see 18 U.S.C. $§ 608(b)(3)$ (Supp. IV 1974) (modified 1976, recodified at 2 U.S.C. $\S 441 \mathrm{a}(\mathrm{a})(3)$ ). 
could be spent by a campaign, by a candidate from her personal funds, and by a noncandidate on behalf of a candidate. ${ }^{20}$

The Court in Buckley applied high First Amendment scrutiny to the restrictions based on its own understanding about the realities of politics. In its analysis, the Court focused primarily on the culturally specific reality that "television, radio, and other mass media" were "indispensable instruments of effective political speech." ${ }^{21}$ According to the Court's understanding of contemporary politics and private markets, the need to purchase airtime or newspaper space from private media outlets made "the raising of large sums of money an ever more essential ingredient of an effective candidacy." 22 The Court believed spending money to be so important to effective political speech that a restriction on spending money effectively constituted a restriction on speech. ${ }^{23}$ The Court's recognition of the reality that spending was closely related to speech prompted it to reject the argument that the need to equalize political opportunities justified limitations on spending, reasoning that "the concept that government may restrict the speech of some elements of our society in order to enhance the relative voice of others is wholly foreign to the First Amendment." 24 Consequently, the Court invalidated spending restrictions. 25

20. The expenditure-limitation provisions were as follows: (1) a $\$ 1000$ annual ceiling on independent expenditures (expenditures by a noncandidate to promote the election or defeat of a clearly identified candidate), see 18 U.S.C. § 608(e)(1) (Supp. IV 1974) (repealed 1976); (2) an annual ceiling on campaign expenditures from a candidate's personal or family funds, see $i d$. $\S 608(a)(1)$; and (3) a variable ceiling on total campaign expenditures from all sources, see id. $\S 608(\mathrm{c})$. This Article is limited to a discussion of the portion of the 1974 Act concerning campaign contributions and expenditures. Buckley also invalidated regulatory provisions providing for the appointment of some FEC commissioners by congressional leaders (based on the separation-ofpowers doctrine), Buckley, 424 U.S. at 138-41, but upheld disclosure, see id. at 60-84, and publicfinancing provisions, see id. at 85-109. For important literature providing additional information on Buckley and the campaign finance dilemma generally, see ANTHONY CORRADO, CAMPAIGN FINANCE REFORM (2000); ISSACHAROFF, KARLAN \& PILDES, supra note 3, at 616-64; LOWENSTEIN, supra note 3, at 507-44 (1995); DANIEL H. LOWENSTEIN \& RICHARD L. HASEN, ELECTION LAW: SUPPLEMENT 2000-2001, 77-127 (2000); and E. JOSHUA ROSENKRANZ, BUCKLEY STOPS HERE: LOOSENING THE JUDICIAL STRANGLEHOLD ON CAMPAIGN FINANCE REFORM (1998).

21. Buckley, 424 U.S. at 19.

22. Id. at 26.

23. See id. at 26; see also id. at $18 \mathrm{n} .17$ (asserting that "the Act's dollar ceilings restrict [ed] the extent of the reasonable use of virtually every means of communicating information") (emphasis added). A number of commentators have interpreted Buckley as equating money with speech. See, e.g., Lillian R. BeVier, Campaign Finance Reform: Specious Arguments, Intractable Dilemmas, 94 Colum. L. REV. 1258, 1277 (1994); Debra Burke, Twenty Years After the Federal Election Campaign Act Amendments of 1974: Look Who's Running Now, 99 DICK. L. REV. 357, 370 (1995); Alan B. Morrison, What If . . Buckley Were Overturned?, 16 CONST. COMMENTARY 347, 369-70 (1999). Contrary to popular opinion, Buckley's initial application of speech doctrine to regulations of political money is not based on the logic that "money is speech" (i.e., that spending is the same thing as speaking). Rather, Buckley's application of speech doctrine was premised on the rationale that money is so important to "effective political speech" that a restriction on spending money effectively constituted a restriction on speech.

24. Buckley, 424 U.S. at 48-49.

25. See id. at 47-48. 
In contrast, the Court upheld the $\$ 1000$ contribution limit. The Court made the context-specific assessment that the contribution limit was sufficiently high so as not to interfere with the ability of candidates to engage in effective advocacy ${ }^{26}$ and that such a limit was needed to prevent corruption and the appearance of corruption. ${ }^{27}$ Such a judgment relies on certain assumptions about economic and political realities, such as what constitutes effective advocacy; how much effective advocacy costs; how large contributions must be to allow candidates to raise enough money to engage in effective advocacy; and at what point contributions are so large that they invite corruption or the appearance of corruption.

A group of scholars who are generally critical of the Reformershereinafter referred to as the "Formalists"-agree with Buckley's invalidation of spending limitations, but many would go a step further and invalidate contribution limitations. ${ }^{28}$ According to the Formalists' understanding of political reality, both contributions and spending are essential to purchasing speaking opportunities in modern democracy, and thus a limitation on either constitutes a limitation on speech. ${ }^{29}$ Furthermore, Formalists observe that approaches that restrict contributions are not sufficiently narrowly tailored to

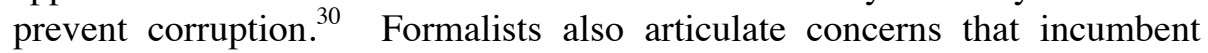
legislators will design campaign finance regulations so as to entrench themselves $^{31}$ and that such regulations may have unintended consequences. ${ }^{32}$

26. See also Nixon v. Shrink Mo. Gov’t PAC, 528 U.S. 377, 397 (2000) (asking whether a contribution limit was so low as to "impede the ability of candidates to 'amas[s] the resources necessary for effective advocacy", and "render political association ineffective, drive the sound of a candidate's voice below the level of notice, and render contributions pointless" (quoting Buckley, 424 U.S. at 21 (brackets in original))). In Nixon, the Court explicitly reviewed contribution limits using a standard of scrutiny that was more stringent than intermediate scrutiny but "different" from the strict scrutiny applied to expenditure limits. See Nixon, 528 U.S. at 385-87.

27. Buckley, 424 U.S. at 26-29.

28. See, e.g., Joel M. Gora, Buckley v. Valeo: A Landmark of Political Freedom, 33 AKRON L. REV. 7, 35 (1999) (observing that those associated with the ACLU would "raise or even repeal all limits on campaign contributions or expenditures"); Kathleen M. Sullivan, Against Campaign Finance Reform, 1998 UTAH L. REV. 311, 315 (observing that if the holding in Buckley was mistaken, "it should be corrected not by finding expenditure limits constitutional, but by finding First Amendment reasons to deregulate contributions"); $c f$. James Bopp, Jr., Constitutional Limits on Campaign Contribution Limits, 11 REGENT U. L. REV. 235, 237 (1998) ("Contribution limits adversely affect our system of representative government by restricting the resources available for political dialogue.").

29. See Colo. Republican Fed. Campaign Comm. v. FEC, 518 U.S. 604, 640 (1996) (Thomas, J., concurring in part and dissenting in part) (explaining that "unlike the Buckley Court, I believe that contribution limits infringe as directly and as seriously upon freedom of political expression and association as do expenditure limits").

30. See D. Bruce LaPierre, Raising a New First Amendment Hurdle for Campaign Finance "Reform,” 76 WASH. U. L.Q. 217, 225 (1998) (asserting that Buckley allowed "Congress to limit political contributions without any evidence that contributions in any particular amounts in excess of $\$ 1000$ caused the harms, corruption, or the appearance of corruption, that inspired the restriction").

31. See Lillian R. BeVier, Money and Politics: A Perspective on the First Amendment and Campaign Finance Reform, 73 CAL. L. REV. 1045, 1080 (1985) ("Contribution limitations ... 


\section{B. Democratic Understandings Embraced by Reformers}

Reformers claim that the Court in Buckley and the Formalists overlook important values and political realities. Various Reformers emphasize different normative concerns about democracy, including the adverse impact of the current campaign finance system on voter turnout, the recruitment of good candidates, the quality of campaign discourse, the integrity of government, the time that incumbent candidates devote to governing, and grass-roots campaigning. ${ }^{33}$ Though not all Reformers agree on a uniform analytical approach or a single reform proposal, identifiable themes appear throughout the scholarship of many Reformers. The most important of these themes relate to equality, the relative nature of rights, the uneven distribution of property, and the role of campaign finance in the larger political process.

While the Court in Buckley rejected equalization as a sufficiently worthwhile justification for spending restrictions, ${ }^{34}$ Reformers put equality back on the table. ${ }^{35}$ Some Reformers describe the intrinsic equality of human

probably increasingly insulate incumbents from changing political opinion in and strong challenges from their local constituencies."); Smith, supra note 16, at 1072 ("Contribution limits tend to favor incumbents by making it harder for challengers to raise money and thereby make credible runs for office. The lower the contribution limit, the more difficult it becomes for a candidate to raise money quickly from a small number of dedicated supporters."); Kathleen M. Sullivan, Political Money and Freedom of Speech, 30 U.C. DAVIS L. REV. 663, 686 (1997) (observing that "[c]ampaign finance limits themselves may help to entrench incumbents in office" because challengers' "lack of prominence may make it more difficult for them to raise funds from large numbers of small donations").

32. See Michael J. Malbin, Looking Back at the Future of Campaign Finance Reform: Interest Groups and American Elections, in MONEY AND POLITICS IN THE UNITED STATES: FinANCING ELECTIONS IN THE 1980S, at 232, 238-43 (Michael J. Malbin ed., 1984) (discussing the unanticipated consequences of campaign finance legislation); BeVier, supra note 31, at 1079-80 (citing examples of how reforms have failed to achieve their goals); Bradley A. Smith, Some Problems with Taxpayer-Funded Political Campaigns, 148 U. PA. L. ReV. 591, 598 (1999) (observing the "propensity of campaign finance regulation to be particularly prone to the law of unintended consequences"); Sullivan, supra note 31, at 687-88 (discussing unintended consequences of campaign finance legislation); see also Cass R. Sunstein, Political Equality and Unintended Consequences, 94 CoLUM. L. Rev. 1390, 1400 (1994) (acknowledging that, despite need for reform, regulation sometimes has unintended consequences).

33. See Vincent Blasi, Spending Limits and the Squandering of Candidates' Time, 6 J.L. \& POL'Y 123, 123 (1997) (stating that fundraising diverts the time and energy officials need to do their jobs); Marshall, supra note 12, at 359-61 (describing normative problems within the political system that favor reform); Marlene Arnold Nicholson, Buckley v. Valeo: The Constitutionality of the Federal Election Campaign Act Amendments of 1974, 1977 WIS. L. REV. 323, 328 ("[C]andidates without ties to wealth are deterred from entering the electoral process ...."); $c f$. Strauss, supra note 15 , at 141 (observing that one cannot determine whether campaign finance reform is needed, and what reforms might be in order, until one identifies "what the objective of any reform effort should be").

34. See Buckley v. Valeo, 424 U.S. 1, 54 (1976) ("The ancillary interest in equalizing the relative financial resources... is clearly not sufficient to justify the...infringement of fundamental First Amendment rights.").

35. See Cass R. Sunstein, Democracy and the Problem of Free Speech 97-98 (1993) (criticizing the Court's rejection of equality as justification for campaign finance reform); Burt Neuborne, Toward a Democracy-Centered Reading of the First Amendment, 93 Nw. U. L. REv. 
beings as an important democratic norm or constitutional goal. ${ }^{36}$ Others explicitly invoke the Fourteenth Amendment, arguing that campaign finance is best understood as an equal-protection problem, rather than as solely a First Amendment problem. ${ }^{37}$ Reformers broadly state that citizens should enjoy sufficiently equal opportunities in persuading others during the argumentative stage of the electoral process, ${ }^{38}$ in participating in public elections as voters and candidates, ${ }^{39}$ and in influencing the outcome of political decisions. ${ }^{40}$

Equality concerns are related to the second theme prevalent in Reformer scholarship-the relational nature of rights. Reformers argue that the Buckley Court should have acknowledged not only the formal individual rights of spenders and contributors but also the rights of those without

1055, 1057 (1999) (“Unless and until political equality re-enters the picture as a permissible reform goal, I see no way out of the current, unsatisfactory situation. I believe that the Buckley Court was unduly hasty in taking equality entirely off the table as a justification for restricting runaway campaign spending."); Nicholson, supra note 33, at 327-40 (arguing for giving great weight to equalization as a justification for campaign finance reform).

36. See Edward B. Foley, Equal-Dollars-Per-Voter: A Constitutional Principal of Campaign Finance, 94 COLUM. L. REV. 1204, 1215 (1994) ("In thinking about distributive justice, I start with the basic premise that all persons have equal intrinsic worth, which I call the principle of intrinsic equality."); Sunstein, supra note 32, at 1392-93 ("In democratic politics, a norm of equality is important: disparities in wealth ought not lead to disparities in power over government.").

37. Jamin Raskin \& John Bonifaz, The Constitutional Imperative and Practical Superiority of Democratically Financed Elections, 94 ColuM. L. REv. 1160, 1164 (1994) [hereinafter Raskin \& Bonifaz, Constitutional Imperative] (arguing that campaign finance "is best formulated in terms of equal protection rather than in the rarified and abstracted language of free speech"); see also Jamin Raskin \& John Bonifaz, Equal Protection and the Wealth Primary, 11 YALE L. \& POL'Y REV. 273, 279 (1993) [hereinafter Raskin \& Bonifaz, Equal Protection] (declaring that "[t]he purpose of this Article is to demonstrate that the current campaign finance regime is inconsistent with equal protection or, at the very least, warrants congressional action to vindicate equal protection").

38. See Foley, supra note 36, at 1227 (stating that "a citizen does not have equal input in the electoral process if she is denied an equal opportunity to participate in the argumentative stage of the process").

39. See Richard L. Hasen, Clipping Coupons for Democracy: An Egalitarian/Public Choice Defense of Campaign Finance Vouchers, 84 CAL. L. REV. 1, 27-28 (1996) (asserting that "[e]galitarian pluralism aims to equalize the ability of different individuals to affect the political process" and is based on the notion that "disparities in wealth and ability to organize are not relevant to the individual's right to influence political outcomes"); Raskin \& Bonifaz, Constitutional Imperative, supra note 37, at 1164 ("Specifically, equal protection requires an inquiry into whether all citizens enjoy sufficient equality in the political field to participate meaningfully in public elections as voters, speakers, and candidates whenever they so desire."); David A. Strauss, Corruption, Equality, and Campaign Finance Reform, 94 Colum. L. REV. 1369, 1382-85 (1994) (asserting those who have money should not be allowed to exert greater influence over the political process through their contributions); Sunstein, supra note 32, at 1392 (listing political equality as a justification for campaign finance reform because " $[\mathrm{t}] \mathrm{he}$ "one person-one vote' rule exemplifies the commitment to political equality" and because "[1]imits on campaign expenditures are continuous with that rule").

40. John RaWls, Political Liberalism 327 (1993) (stating that the "fair value" of the political liberties requires that each citizen have "approximately equal, or at least sufficiently equal," opportunities to "influence the outcome of political decisions"). 
resources. ${ }^{41}$ Democracy, it is argued, requires more than the consideration of individual rights in a vacuum-democracy demands an understanding of the relative nature of all participants' rights. $^{42}$ In rejecting Buckley's oversimplified notion of "rights," which focuses on the individual interests of contributors and spenders, the Reformers take into account the varied interests of all citizens. ${ }^{43}$ Reformers assert that democracy has an interest not only in protecting formal political liberties from interference by government but also in taking steps to ensure that political liberties are real and meaningful to citizens who might otherwise lack the resources to enjoy their liberties. $^{44}$

Reformers assert that a mechanical protection of the individual rights of those with resources overlooks important First Amendment structural concerns. Some argue that democracy needs campaign finance reform to advance a primary purpose of freedom of speech-attainment of wellfunctioning speech markets that feature robust public debate from a variety of perspectives. ${ }^{45}$ Some campaign finance reform, Reformers argue, advances the First Amendment by promoting meaningful and diverse political deliberation that includes all social groups. ${ }^{46}$ Reformers do not use

41. See Raskin \& Bonifaz, Constitutional Imperative, supra note 37, at 1165 ("The key First Amendment issue at stake in this debate is not the right of the wealthy to spend up to the heavens, but the right of all citizens, poor and wealthy alike, to speak and participate meaningfully in the electoral process.").

42. See J.M. Balkin, Some Realism About Pluralism: Legal Realist Approaches to the First Amendment, 1990 DUKE L.J. 375, 404 (observing that "public expansion or contraction of rights is really an issue of relations of power between private individuals" and that a legal realist approach allows for a reinterpretation of First Amendment law "in terms of private power and subordination").

43. Cf. Nixon v. Shrink Mo. Gov't PAC, 528 U.S. 377, 402 (2000) (Breyer, J., concurring) (arguing for a new approach of judicial review to campaign finance regulations, stating that "where a law significantly implicates competing constitutionally protected interests in complex ways - the Court has ... refrained from employing a simple test that effectively presumes unconstitutionality," and has instead balanced interests).

44. RAWLS, supra note 40, at 327 (explaining that "the first principle of justice [should include] the guarantee ... that the worth of the political liberties to all citizens, whatever their social or economic position, [is] approximately equal, or at least sufficiently equal, in the sense that everyone has a fair opportunity to hold public office and to influence the outcome of political decisions"); see Sunstein, supra note 32, at 1390 ("Government has a legitimate interest in ensuring not only that political liberties exist as a formal and technical matter, but also that those liberties have real value to the people who have them.").

45. See Cass R. Sunstein, Free Speech Now, in ThE Bill of Rights In the Modern StATE 255, 267 (Geoffrey R. Stone et al. eds., 1992) ("[I]n some circumstances, what seems to be government regulation of speech actually might promote free speech, and should not be treated as an abridgement at all... [Further] what seems to be free speech in markets might, in some selected circumstances, amount to an abridgement of free speech.").

46. See Raskin \& Bonifaz, Constitutional Imperative, supra note 37, at 1168 ("The political dialogue protected by the First Amendment is central to the project of democratic self-government, a principle recognized-but then badly distorted-by the Supreme Court in Buckley v. Valeo."); Sunstein, supra note 32, at 1392 ("Campaign finance laws might promote the goal of ensuring political deliberation and reason-giving. Politics should not simply register existing preferences and 
words like "wealth," "class," "rich," or "poor" merely to describe economic status; often they also use these words to describe political identity, acknowledging that poor citizens might articulate different political priorities than rich citizens. ${ }^{47}$ Absent reform, "the quality and breadth of political communication and debate suffer," decisions based on private interest rather than on reasoned political deliberation. ${ }^{49}$

Owen Fiss, for example, argues that some restrictions on political money may prevent a distortion of public debate and advance a more democratic understanding of the First Amendment. ${ }^{50}$ Campaign finance reform that benefits poorer candidates may advance First Amendment interests if it is designed to enhance the information available to the electorate. $^{51}$ Admittedly, such reform might give greater benefits to poorer candidates, but privately financed elections also lack neutrality because they benefit wealthier candidates over others, and the existing distribution of financial resources need not be the constitutional baseline. ${ }^{52}$

their intensities, especially as these are measured by private willingness to pay ... [P]olitics has an important deliberative function. The constitutional system aspires to a form of 'government by discussion.",").

47. See Owen Fiss, Money and Politics, 97 ColuM. L. REv. 2470, 2480 (1997) ("Relying upon private wealth to finance public elections, even if it is the candidates' own money, thus has two unwelcome effects on politics: it prevents voters from hearing certain perspectives, and it prevents some would-be participants in the political process from effectively airing their views."); Neuborne, supra note 35, at 1072 ("A campaign financing system driven by extreme wealth disparity will inevitably reflect the needs and concerns of the persons who pay for the system, and it will ignore the needs and concerns of persons who lack the means to participate in the funding process.... This means that issues of importance to the holders of great wealth are more likely to find themselves on the agenda than issues of importance to the poor."); Raskin \& Bonifaz, Constitutional Imperative, supra note 37, at 1189 ("Moreover, the electoral system is closed not to random groups of citizens but specifically to less-affluent groups, who enjoy reduced access to the means of candidacy, the political process and government. With whole sectors of the population marginalized in the electoral process, the quality and breadth of political communication and debate suffer.").

48. Raskin \& Bonifaz, Constitutional Imperative, supra note 37, at 1189.

49. See Sunstein, supra note 32, at 1392 ("Grants of cash to candidates might compromise that goal by, for example, encouraging legislatures to vote in accordance with private interest rather than reasons.").

50. See Fiss, supra note 47, at 2479 (asserting that an expenditure regulation "might be defended ... on the ground that it prevents a distortion of public debate" and that such a regulation is "rooted in a democratic understanding of the First Amendment").

51. See id. at 2480 ("But if its justification were to enhance the information available to the electorate, as indeed might be the case with expenditure limits, there would be no breach of the requisite neutrality.").

52. See id. at 2481. As Fiss points out:

Admittedly, any system of public financing will favor some candidates or would-be candidates over others and in that sense be non-neutral. But so would a system that relied on private wealth. It too favors some candidates over others, since some have the money needed and others do not; yet, there is no reason to privilege that arrangement and to treat it as the constitutional baseline.

Id. 
Jack Balkin and Cass Sunstein observe that the inequities in political participation under the current campaign finance system arise directly from a preexisting unequal distribution of property. ${ }^{53}$ The government, they note, has created a system of property laws that makes inequalities in property possible. $^{54}$ Thus, the government is responsible for the political advantages that some actors enjoy under the current campaign finance system. ${ }^{55}$

Just as Reformers realize that mechanical applications of First Amendment doctrine to campaign finance are unwarranted, they also recognize that campaign finance is an essential component of the larger political process. ${ }^{56}$ Voting, some Reformers argue, is only one part of the political process ${ }^{57}$ and full and meaningful political participation requires more than the grant of a formal vote. ${ }^{58}$ This more comprehensive understanding

53. See Balkin, supra note 42 , at 379 . Balkin explains further:

One could argue that free speech in a situation of radically unequal economic power is not free speech at all because it is skewed by the preexisting distribution of property.... The long term effect of the unequal distribution of power and property is an unequal exposure of particular ideas, and the stifling and co-opting of more radical and imaginative ideas about politics and society.

Id.

54. See id. at 414 ("The government is responsible for inequalities in access to the means of communication because it has created the system of property rights that makes such inequalities possible."); Sunstein, supra note 32, at 1399 (“[E]lections based on existing distributions of wealth and entitlements also embody a regulatory system, made possible and constituted through law. Here as elsewhere, law defines property interests; it specifies who owns what, and who may do what with what is owned.").

55. See Balkin, supra note 42 , at 414 (" $[\mathrm{I}] \mathrm{t}$ is not only wrong but also incoherent for opponents of campaign finance reform to contend that the government should not regulate access to the political process. Government already regulates access to the political process - the first amendment simply demands that it do so fairly. At the very least the first amendment should not act as a barrier to attempts to ensure that the process works equitably."); Sunstein, supra note 32, at 1399 ("Efforts to redress economic inequalities, or to ensure that they are not turned into political inequalities, should not be seen as impermissible redistribution, or as the introduction of government regulation into a place where it did not exist before. A system of unlimited campaign expenditures should be seen as a regulatory decision to allow disparities in resources to be turned into disparities in political influence.”).

56. Cf. Daniel R. Ortiz, From Rights to Arrangements, 32 LoY. L.A. L. Rev. 1217, 1222 (1999) ("[S]hifting the lens through which we view campaign finance from the right to free speech to the right to participate highlights completely different issues. It radically transforms the terms of the debate, but does not necessarily settle it.").

57. See Foley, supra note 36, at 1226 . Foley divides the electoral process into three stages:

Voting is only the final stage of the electoral process. It is preceded not only by the agenda-formation stage (in which matters to be voted upon are identified) but also by what might be called the 'argumentative stage,' in which competing factions of the electorate attempt to persuade the mass of undecided voters to agree with their positions.

Id.

58. See Raskin \& Bonifaz, Equal Protection, supra note 37, at 300-01 ("When citizens of modest means go to the polls, they are voting for candidates whose political seriousness has been determined by a money-gathering process which, by definition, systematically demotes their interests.... [T] hey are part of an electoral system 'arranged in a manner that will consistently degrade' their influence 'on the political process as a whole."' (quoting Davis v. Bandemer, 478 
appreciates the importance of a well-functioning democratic structure ${ }^{59}$ and finds fault with the systemic disparities in power that private wealth brings to the political process. ${ }^{60}$

Burt Neuborne, for example, proposes a "democracy-centered" reading of the First Amendment, which views the constitutional provision "not only as a protector of individual autonomy, but also as the structural guarantor of a fair democratic process." ${ }^{\prime 1}$ To Neuborne, the First Amendment not only protects individual autonomy from democracy but also protects democracy from harmful autonomy. ${ }^{62}$ Collective decisionmaking is not necessarily best realized through the protection of individual First Amendment rights. Neuborne asserts that the First Amendment prioritizes campaign finance reforms that benefit democracy over a judicial mandate of unlimited spending that impairs democracy. ${ }^{63}$

In contrast to the Formalists' perception that money is analogous to speech in the political process, Reformers often use analogies to voting and borrow language from the voting rights and reapportionment contexts to emphasize the role of money in the political process. ${ }^{64}$ For example, a structural critique by Jamin Raskin and John Bonifaz describes an existing campaign finance process in which wealthy contributors preselect almost all viable candidates (a process Raskin and Bonifaz deem the "wealth

U.S. 109, 132 (1986))); see also S. REP. No. 97-117, at 19 (1982) ("There is more to the right to vote than the right to mark a piece of paper and drop it in a box or the right to pull a lever in a voting booth ...." (quoting Reynolds v. Sims, 377 U.S. 533, 555 n.29 (1964))), reprinted in 1982 U.S.C.C.A.N. 177, 196.

59. See Neuborne, supra note 35, at 1058 ("Viewed solely as a means of disabling government, a purely 'autonomy-centered' First Amendment can be affirmatively hostile to democracy by insulating private activity from regulation despite its deleterious effect on democracy.").

60. See, e.g., id. at 1072 ("[W] ealth disparity introduces massive political inequality skewed to a predictable set of self-interested positions.... For the same reasons we rejected property qualifications for voting and running for office ... we should be extremely concerned with a set of institutional decisions that creates massive wealth-driven disparities in political power."); Balkin, supra note 42, at 414 ("[W]e should isolate the egalitarian assumptions implicit in the "money is not speech' position and put them to their best use - the justification of campaign finance reforms on the grounds that 'gross inequalities' of economic power destroy the integrity of the political process.").

61. Neuborne, supra note 35 , at 1059.

62. See id. at 1068 ("[T]he question arises whether other possible visions exist that might supplant, or at least supplement, the traditional autonomy model. One such vision is to insist that the First Amendment's role is not solely to protect autonomy against democracy, but also to enable and protect democracy against harmful autonomy.").

63. See id. at 1070 ("Read as a bulwark of democracy (as well as a protection of individual autonomy), the First Amendment tells us that, when more than one candidate for First Amendment autonomy protection exists in a democracy case, the Court should privilege behavior that benefits democracy rather than behavior that saps its vitality.").

64. See, e.g., Foley, supra note 36, at 1220 ("To give the rich more votes than the poor just because they are rich would be a form of elitism in violation of the principle of intrinsic equality. The interests of poor citizens must count the same as the interests of rich citizens."). 
primary"). ${ }^{65}$ This practice does not leave the political process equally open; instead, it denies voters meaningful electoral choice ${ }^{66}$ and degrades their "influence on the political process as a whole." ${ }^{.67}$ Raskin and Bonifaz also argue that large out-of-state contributions work to "dilute the zealous independent representation of the people of each state . . by making elected officials more accountable to the nationalized interests of specific wealthy groups and industries. ${ }^{\circ 8}$ Similarly, out-of-district contributions offend oneperson, one-vote principles by expanding the political power of wealthier districts and reducing the power of poorer districts. ${ }^{69}$ Raskin and Bonifaz criticize the existing campaign finance system not only for the inequitable access it provides to potential candidates and voters ${ }^{70}$ but also for the structural bias in government decisionmaking that results. ${ }^{71}$

65. See Raskin \& Bonifaz, Equal Protection, supra note 37, at 287. The authors identify several features of the federal campaign process:

[E]xorbitant costs that effectively freeze out poorer candidates, stack the deck in favor of candidates backed by wealth and incumbency, and reduce electoral choice; an almost invisible network of public and private campaign subsidies to incumbents; the critical role of private money in producing (and predicting) electoral victory; and a process increasingly dominated by wealth in ways that systematically discourage full political dialogue, participation, and competition.

Id.

66. See id. at 280 (asserting that the effect of the wealth primary is that it "sharply reduces voter choice"); see also 42 U.S.C. § 1973(b) (1994) (protecting minority racial groups from electoral systems that afford them "less opportunity . . . to elect representatives of their choice").

67. Raskin \& Bonifaz, Equal Protection, supra note 37, at 279-80 (quoting Davis v. Bandemer, 478 U.S. 109, 132 (1986), which found that partisan gerrymandering violates equal protection when "the electoral system is arranged in a manner that will consistently degrade a voter's or a group of voters' influence on the political process as a whole").

68. Raskin \& Bonifaz, Equal Protection, supra note 37, at 306.

69. See id. (arguing that "the constitutional principles of one person/one vote and election by 'the people' are especially offended by the spending of campaign money in House and Senate races raised out-of-state" and that employing such a process "potentially expands the political power of wealthier states, like New York and California, while reducing the power of poorer states").

70. Raskin and Bonifaz describe the problem that the poor face under the current system:

[W] contend that the current regime - the combination of the "wealth primary" and incumbent self-subsidies - sets up an economic gauntlet that, in "every practical sense," prevents less affluent candidates-"potential office seekers lacking both personal wealth and affluent backers"-from competing for office. This system sharply reduces voter choice and "falls with unequal weight on voters, as well as candidates, according to their economic status ...." This effect denies huge numbers of people meaningful electoral choice and unlawfully degrades their influence on the political process as a whole.

Id. at 279-80 (quoting Bullock v. Carter, 405 U.S. 134, 143-44 (1972)).

71. See Raskin \& Bonifaz, Constitutional Imperative, supra note 37, at 1202 (observing that after reform "the current wealth and class-based exclusion of political candidates - along with its corresponding structural bias in government-would be eliminated"). 


\section{Campaign Finance Through the Framework of Race}

While the Reformers claim that the Court in Buckley overlooked important political realities, the Reformers' class-based analysis is incomplete as well because it ignores critical factors related to race. ${ }^{72}$ Reformers focus on issues of equality and access and compare exclusion in the campaign finance context to racial exclusion in the voting rights context to make their case. ${ }^{73}$ Nevertheless, Reformers have not examined policies that have illegitimately shaped the distribution of property, such as past statesanctioned discrimination against racial minorities and the impact of these historical policies on the current racial distribution of wealth and the ability of racial minorities to participate in a privately financed political system. ${ }^{74}$

72. Although a few Reformers have briefly acknowledged isolated examples of how campaign finance may affect people of color, the scholars have not engaged in a comprehensive analysis of the significance of race in the campaign finance context. For example, Jamin Raskin and John Bonifaz acknowledge that financial disadvantages faced by minority candidates may implicate concerns under $\S 2$ of the Voting Rights Act, but they relegate their examination to a footnote. See Raskin \& Bonifaz, Equal Protection, supra note 37, at 279 n.26. The scholars admit that their research is "[p]reliminary" and that "[t]he question of a Voting Rights Act violation ... is beyond the scope of this Article." Id. Cass Sunstein briefly mentions that "[s]ometimes minority candidates can succeed only with the help of PACs specifically organized for their particular benefit. For this reason, PAC limits will in some circumstances diminish the power of minority candidates." Sunstein, supra note 32, at 1409-10. Sunstein uses this example to explain why campaign finance restrictions are sometimes problematic, but he does not engage in a specific analysis of the costs and benefits to people of color of PAC contribution limits, nor does he offer a more comprehensive analysis of how the current campaign finance system as a whole may benefit or disadvantage people of color. Richard Hasen briefly acknowledged race-based identities in his piece calling for a public system that allows citizens, rather than government, to allocate public resources to candidates. See Hasen, supra note 39, at 56-58. Terry Smith, who has written primarily on minority political participation in the voting rights context, served as the principal author on a "race and campaign finance" panel that was a part of a voting rights symposium sponsored by the North Carolina Law Review. Smith examined theoretical issues, such as the different meanings that certain election-reform groups attach to the term "political equality." Smith also sketched out policy issues related to legislative proposals to reform campaign finance. Other participants on the panel responded to Smith's article. See Smith, supra note 6; Issacharoff, supra note 6; Daniel H. Lowenstein, supra note 6; Spencer Overton, Voices From the Past: Race, Privilege, and Campaign Finance, 79 N.C. L. REV. 1541 (2001). In addressing legislative reforms, subpart $\mathrm{V}(\mathrm{B})$ of this Article examines these commentators' opinions.

73. See, e.g., Raskin \& Bonifaz, Equal Protection, supra note 37, at 308-09 (comparing the "white primary" that excluded African Americans from the selection of candidates (invalidated by Terry v. Adams, 345 U.S. 461 (1953)) to the "wealth primary" of the current campaign finance system, which excludes the poor from determining who will be able to run for office).

74. Several civil-rights and campaign finance activists have addressed race and campaign finance at conferences sponsored by Howard Law School and the National Voting Rights Institute, the Brennan Center, and the Asian Law Journal at the University of California, Berkeley. The presentations contained critiques by activists, policymakers, and legal practitioners. They did not, however, constitute comprehensive treatment of race and campaign finance by academic legal commentators. See, e.g., John Bonifaz et al., Comment, Challenging the Campaign Finance System as a Voting Rights Barrier: A Legal Strategy, 43 How. L.J. 63 (1999); Roger Wilkins et al., Comment, Campaign Finance as a Civil Rights Issue, 43 How. L.J. 41 (1999); Edward M. Chen, Introduction to Edward M. Chen \& Dale Minami, Nat'l Asian Pac. Am. Legal Consortium et al., Petition for Hearing Before the U.S. Commission on Civil Rights, 5 ASIAN L.J. 353 (1998); Edward 
Note that the analysis advanced in this Part focuses primarily on the racial identity of citizens and contributors, rather than on the racial identity of the candidates who receive money. The ability of candidates of color to attract sufficient funds is important as a policy matter but is not, in and of itself, the end game. ${ }^{75}$ Concentrating solely on the success of candidates of color ignores the reality that candidates are accountable, in part, to contributors. Contributors determine which candidates of color can run viable campaigns, but these contributors do not always accurately reflect the interests of minority citizens. For example, one might overstate racial progress by focusing exclusively on the electoral success of a candidate of color whose campaign has been financed almost exclusively by white contributors. Further, focusing solely on the electoral success of candidates of color dismisses the essential role of citizen participation, choice, and influence inherent in campaign finance-all forms of democratic participation that would have independent constitutional value even if candidates of color and contributors always faithfully represented the interests of citizens of color.

To understand the structural problems inherent in the existing campaign finance system, one must consider how racial discrimination has influenced the distribution of property. Noble factors such as hard work, discipline, and intelligence only partially shape the current property distribution. This Part analyzes historical and contemporary racial realities, which the Reformers have often overlooked, to create a framework that allows for a broader, more comprehensive critique of current campaign finance jurisprudence.

M. Chen \& Dale Minami, Nat'l Asian Pac. Am. Legal Consortium et al., Petition for Hearing Before the U.S. Commission on Civil Rights, 5 ASIAN L.J. 357 (1998); L. Ling-chi Wang, Beyond Identity and Racial Politics: Asian Americans and the Campaign Fund-Raising Controversy, 5 ASIAN L.J. 329 (1998). A number of individuals and civil-rights groups represented at the Howard conference convened and established The Fannie Lou Hamer Project, which recognizes campaign finance as a civil-rights issue and explores the racial impact of the current campaign finance system. See The Fannie Lou Hamer Project, at http://www.flhp.org (last visited Apr. 1, 2002); see also Ben White, Shadow Moves to New Venue with Old Issue, WASH. PoST, Aug. 17, 2000, at A15, 2000 WL 25410546 (describing efforts of The Fannie Lou Hamer Project "to encourage Americans to think of campaign finance reform as a civil rights issue").

While this Article criticizes the academic writings of Jamin Raskin and John Bonifaz for focusing solely on class to the exclusion of race, it is worth noting that Bonifaz was a principal figure in organizing the Howard conference and The Fannie Lou Hamer Project. Also, in addition to the Berkeley conference, others have discussed the campaign finance investigations of Asian Americans following the 1996 Presidential Elections. See, e.g., Bruce D. Brown, Alien Donors: The Participation of Non-Citizens in the U.S. Campaign Finance System, 15 YALE L. \& POL'Y REV. 503 (1997); Jessica S. Horrocks, Note, Campaigns, Contributions and Citizenship: The First Amendment Right of Resident Aliens to Finance Federal Elections, 38 B.C. L. REV. 771 (1997).

75. The protection of voters of color, rather than candidates of color, is the primary concern of the Voting Rights Act. See Thornburg v. Gingles, 478 U.S. 30, 68 (1986) ("[T]he fact that race of voter and race of candidate is often correlated is not directly pertinent to a $\S 2$ inquiry. Under $\S 2$, it is the status of the candidate as the chosen representative of a particular racial group, not the race of the candidate, that is important.") 


\section{A. Past Discriminatory Policies Shape Property Distribution ${ }^{76}$}

Governmental entities have long used racial identity to define and allocate property rights. Official government action in the form of proclamations, statutes, and court decisions took land from Native Americans based on their racial and cultural identity and reallocated this property to white private actors. ${ }^{77}$ The law contemplated and enforced the appropriation of labor from African Americans through slavery, ${ }^{78}$ which primarily benefited white private actors. ${ }^{79}$ The law also promoted immigration from European countries, essentially determining the racial makeup of those who would count as full citizens in the United States. ${ }^{80}$ As white Americans

76. While this section concentrates primarily on African Americans, Latinos, Asian Americans, and Native Americans in the United States, the analysis is not limited to these groups. Distributions of property have been illegitimate for other reasons, including but not limited to gender discrimination. See generally, e.g., NAT'L COUNCIL Of NEGRo WOMEN, WOMEN \& Housing: A REPORT ON SEX DISCRIMINATION IN FIVE AMERICAN CITIES, at iv (1975) (reporting problems "that women in American cities face when they try to acquire and maintain a decent place to live"). The analysis is also applicable to groups in other democracies whose lack of control over resources stems in large part from historical decisions based on race or ethnicity, such as many indigenous and formerly segregated or enslaved peoples throughout North and South America, South Africa, Zimbabwe, Australia, and other places. Note that while this Article makes a value-based judgment that racially discriminatory rules are illegitimate, the Article recognizes the absence of a universally accepted baseline from which to identify legitimate laws or allocations of property.

77. See Joseph W. Singer, The Continuing Conquest: American Indian Nations, Property Law, and Gunsmoke, 1 RECONSTRUCTION 97, 102 (1991) ("[P]roperty and sovereignty in the United States have a racial basis. The land was taken by force by white people from peoples of color thought by the conquerors to be racially inferior."); WILLIAM B. SCOTT, IN PURSUIT OF HAPPINESS: AMERICAN CONCEPTIONS OF PROPERTY FROM THE SEVENTEENTH TO THE TWENTIETH CENTURY 1, 6 (1977) (noting royal control of land grants and the tradition of individual freehold ownership, both of which contributed to the appropriation of land occupied by primitive aboriginal tribes).

78. $C f$. John Locke, Of Property, in PROPERTY: MAINSTREAM AND CRITICAL POSITIONS 15, 18 (C.B. MacPherson ed., 1992) ("[E]very Man has a Property in his own Person. . . The Labour of his Body, and the Work of his Hands, we may say, are properly his.”).

79. See Cheryl I. Harris, Whiteness as Property, 106 HARV. L. REV. 1707, 1718 (1993) ("The social relations that produced racial identity as a justification for slavery also had implications for the conceptualization of property. This result was predictable, as the institution of slavery, lying at the very core of economic relations, was bound up with the idea of property. Through slavery, race and economic domination were fused."). But $c f$. Lea S. Vandervelde, The Labor Vision Of The Thirteenth Amendment, 138 U. PA. L. REV. 437, 466 (1989) ("Slavery was evil because it destroyed much of the richest land in the South; it degraded labor and the meaning of labor for poor white working men in the South.... Thus, slavery pulled white workers down in two ways: one, by direct competition with slave labor in the South, and two, by associating all the industrious efforts of workers with those of the degraded slaves.").

80. See T. AleXANDER Aleinikoff ET Al., IMmigration AND Citizenship: Process AND POLICY 152 (4th ed. 1998) ("Some federal [immigration] laws have been blatantly racist, prohibiting immigration and naturalization of aliens from China and Japan and favoring northern and western Europeans over southern and eastern Europeans."); Louis Henkin, The Constitution and United States Sovereignty: A Century of Chinese Exclusion and Its Progeny, 100 HARV. L. REV. 853, 859 (1987) ("The Chinese Exclusion doctrine and its extensions have permitted, and perhaps encouraged, paranoia, xenophobia, and racism, particularly during periods of international tension."); Kevin R. Johnson, Race, the Immigration Law, and Domestic Race Relations: A “Magic Mirror" into the Heart of Darkness, 73 IND. L.J. 1111 (1998) (analyzing the relationship between 
moved west in the 1800 s, the law tolerated discriminatory practices in the Southwest that stripped Mexican Americans of nearly all opportunities to own property. ${ }^{81}$ In addition to conquest, slavery, and immigration policy, well-known public and private racial barriers in education, employment, and business disadvantaged people of color while benefiting others by artificially reducing competition. ${ }^{82}$

Less apparent factors also help perpetuate economic disparities between whites and people of color. The benefits derived from facially discriminatory government policies may be multiplied by facially neutral government policy and economic markets, and may thus have a greater impact today than they did when originally enacted. For example, the Federal Housing Administration (FHA), formed in 1934, promoted a model racially restrictive covenant that whites could use to maintain neighborhood "stability," thereby explicitly promoting segregated home ownership among whites, and discouraging home ownership among nonwhites. ${ }^{83}$ Federally subsidized mortgages often required that owners incorporate into their deeds racially restrictive covenants, ${ }^{84}$ and builders adopted the covenants so that

the history of racial discrimination in immigration law and the civil rights of racial minorities in the United States).

81. See generally Frank D. BEAN \& MARTA TIENDA, THE HisPaniC Population OF THE UNITED STATES 17-22 (1987) (discussing the oppression of Mexican American landowners by Anglo settlers after the Mexican-American War); CHARLES F. MARDEN ET AL., MinORITIES IN AMERICAN SOCIETY 135, 142, 152, 259-91 (1992) (discussing Mexican American immigration and dominance by Anglo settlers); MARTIN N. MARGER, RACE AND ETHNIC RELATIONS 285-90 (2000) (noting that Mexicans' property was taken "through official and unofficial force and fraud").

82. See Melvin L. Oliver \& Thomas M. Shapiro, Black Wealth / White Wealth: A NEW PERSPECTIVE ON RACIAL INEQUALITY 51 (1995) (stating that "every circumstance of bias and discrimination against blacks has produced a ... positive gain for whites"); GILBERT THOMAS STEPHENSON, RACE DISTINCTIONS IN AMERICAN LAW (1910) (arguing that race distinctions in laws have hampered the economic and educational opportunities of African Americans).

83. See KenNeth T. JACKSON, CRABgRASS FrOnTIER 207-18 (1985) (recounting the development of Federal Housing Administration appraisal standards that discriminated against African American communities by favoring lending in homogenous subdivisions); DoUGLAS S. MASSEY \& NANCY A. DENTON, AMERICAN APARTHEID: SEGREGATION AND THE MAKING OF THE UNDERCLASS 53-55 (1993) (documenting the effect of discrimination resulting from Federal Housing Administration appraisal procedures in neighborhoods comprised of "inharmonious racial or nationality groups"); OLIVER \& SHAPIRO, supra note 82, at 39-41 (analyzing the continued effects of the earlier FHA policies). In addition to housing policies that promoted home ownership along racial lines, a number of other government policies have promoted racial disparities in property distribution. For example, "[i]n the first half of the twentieth century, various western states passed 'alien land laws' that limited the right to own property to aliens racially eligible to naturalize, thereby effectively prohibiting foreign-born Asian residents from acquiring certain types of land." SINGER, supra note 10, at 42; see also Oyama v. California, 332 U.S. 633, 640 (1947) (invalidating specific application of California's Alien Land Law as violating the Equal Protection Clause of the Fourteenth Amendment).

84. Richard Thompson Ford, The Boundaries of Race: Political Geography in Legal Analysis, 107 HARV. L. REV. 1841, 1848 (1994) (citing Charles AbRAMS, ForbIDDEN NeIGHBORS: A STUDY OF PREJUDICE IN HOUSING 234-35 (1955)). 
their property qualified for federal insurance. ${ }^{85}$ After perpetuating this segregation, the federal government, concerned more about race than any other demographic trend, "consistently gave black neighborhoods the lowest rating for purposes of distributing federally subsidized mortgages." lenders often followed the federal system in making loan decisions. ${ }^{87}$

The racial disparity in wealth realized through home ownership and home value originally caused by federal housing policies has since been compounded by seemingly neutral public and private decisions. Because people of color are less likely to own homes, they are less likely to take advantage of tax provisions allowing for the deduction of a large percentage of their housing costs (all property taxes and mortgage interest). ${ }^{88}$ Further, the home values appreciated dramatically during the period between 1934 and the 1970s, and this increase benefited whites more than people of color. ${ }^{89}$ Even people of color who were able to purchase homes were less likely than whites to benefit from increasing home values because of the slower rate of appreciation of property in nonwhite areas. ${ }^{90}$

\section{B. People of Color Control Fewer Resources}

Intergenerational transfers of wealth have carried forward past racial disparities in wealth that arose directly from state-sponsored discrimination. ${ }^{91}$ While assets conveyed at death are important and constitute perhaps the most

85. See Ford, supra note 84, at 1848 (citing Martha Mahoney, Note, Law and Racial Geography: Public Housing and the Economy in New Orleans, 42 STAN. L. REV. 1251, 1258 (1990)).

86. See Ford, supra note 84, at 1848 \& n.9 (1994) (citing JACKSON, supra note 83, at 198-99; MASSEY \& DENTON, supra note 83 , at 52).

87. See Ford, supra note 84, at 1848 \& n.9 (citing MASSEY \& DENTON, supra note 83, at 52).

88. See I.R.C. $\S \S 164(a), 163(h)(2)(D)-(3)$ (2000); OLIVER \& SHAPIRO, supra note 82, at 44 (“[T]he U.S. tax code channels benefits and encourages property and capital asset accumulation differentially by race.”).

89. See Richard Banks, Nondiscriminatory Perpetuation of Racial Subordination, 76 B.U. L. REV. 669, 684-85 (1996) (reviewing OLIVER \& SHAPIRO, supra note 82).

90. See RAYMOnd S. Franklin, SHAdOWS OF RACE AND Class 124-25 (1991) (noting that homes owned by middle-class African Americans "do not appreciate as rapidly in value over time as homes owned by whites"); OLIVER \& SHAPIRO, supra note 82, at 40, 150 (observing that "similar housing investments made by whites and blacks yield vastly divergent returns - to the distinct disadvantage of blacks"); Reynolds Farley et al., Stereotypes and Segregation: Neighborhoods in the Detroit Area, 100 AM. J. SoC. 750 (1994) (arguing that racial stereotypes play an important role in explaining whites' resistance to living in integrated neighborhoods); Ford, supra note 84, at 1849-52, 1861 (arguing that race-neutral legal doctrine reinforces residential segregation created by public policy and private actors, causing significant disparity in the appreciation of homes owned by African Americans compared with homes owned by whites, in education, and in political influence).

91. See Dalton Conley, Being Black, Living in the Red: Race, Wealth and Social POLICY IN AMERICA 42-53 (1999) (arguing that many racial inequities result from the disparities in accumulated family wealth). 
obvious way that people pass on wealth, ${ }^{92}$ wealth also flows from other types of intergenerational transfers. For example, wealth commonly derives from the "education, experiences, friendships, and contacts" a child obtains from parents. ${ }^{93}$ Whites also disproportionately tend to receive financial assistance from parents to handle the challenges of early adulthood. For example, whites are twice as likely as African Americans to receive family assistance in purchasing a home. ${ }^{94}$ Despite being motivated by a concern for offspring rather than racial animus, intergenerational transfers of wealth perpetuate the effects of racially discriminatory policies from over a century ago, such as slavery and conquest. These intergenerational transfers also perpetuate discriminatory policies enforced only a few decades ago, such as racially disparate immigration policy and segregation in education, employment, and housing.

The effects of past discriminatory policies are partially reflected in contemporary disparities in income among racial groups. ${ }^{95}$ Income is relevant in the campaign finance context because those with higher incomes are likely to make more and larger political expenditures and contributions. ${ }^{96}$ In

92. See OLIVER \& SHAPIRO, supra note 82, at 155 ("Assets bequeathed at death are ... [the] most direct form of inheritance.").

93. See id. at 152; Ngina S. Chiteji \& Frank P. Stafford, Portfolio Choices of Parents and their Children as Young Adults: Asset Accumulation by African-American Families, 89 AM. ECON. REV. 377, 377-80 (1999) (studying cross-generational influences on wealth and finding that a young family's likelihood of owning stock, a home, and other assets is influenced by whether parents held these financial assets).

94. See OLIVER \& SHAPIRO, supra note 82, at 145 (citing an observation by the Los Angeles Survey of Urban Inequality that whites are twice as likely as African Americans "to receive family assistance in purchasing a home").

95. Income consists of the amount of money an individual or household earns during a given period, and includes earnings, unemployment compensation, workers' compensation, social security, supplemental security income, public assistance, payments to veterans, survivor benefits, and disability benefits. U.S. BUREAU OF THE CENSUS, CURRENT POPULATION SURVEY (CPS) DEFINITIONS AND EXPLANATIONS (2000), available at http://www.census.gov/population/www/ cps/cpsdef.html.

96. Of contributors to 1996 congressional elections who responded to an academic survey funded by the Joyce Foundation and directed by scholars at a number of universities, $81 \%$ had annual incomes over $\$ 100,000$, and $20 \%$ had annual incomes higher than $\$ 500,000$. See Green et al., supra note 2, at 13. While African Americans, Asian Americans, Latinos, and Native Americans comprise approximately $30 \%$ of the population of the United States, they constitute only $9 \%$ of the Americans who make more than $\$ 100,000$. See CENSUS POPULATION ESTIMATES, supra note 1, at 1 (indicating that as of November 1, 2000, African Americans made up 12.8\%, Hispanics 11.9\%, Asian Americans 4.1\%, and American Indians, Eskimos, and Aleuts $0.9 \%$ of the population of the United States); Andrew Hacker, The Rich: Who They Are; The Upper Tail, N.Y. TIMES, Nov. 19, 1995, at 70, LEXIS, Nexis Library, NYT File ("In 1993, about 2.7 million men and women made more than $\$ 100,000$. Of those 2.7 million . . .91 percent are white. People who identify themselves as Asian, Hispanic [or] African-American each make up about 3 percent.”). Even minor differences in income affect the amount that an individual is likely to contribute to political campaigns. See Henry E. Brady et al., Beyond SES: A Resource Model of Political Participation, 89 AM. POL. SCI. REV. 271, 285 (1995) (finding that an otherwise average person's political contributions will increase by more than $50 \%$ when the person's income is increased by $\$ 10,000$ ). 
1995 , median household income was $\$ 35,766$ for whites, $\$ 22,860$ for Latinos, and \$22,393 for African Americans. ${ }^{97}$ While Asian Americans as a whole have higher median household incomes than whites do, a number of Asian American ethnic groups face economic challenges similar to those faced by African Americans, Latinos, and Native Americans. For example, in 1989, the most recent year in which census data on the income of specific Asian American ethnic groups is available, the median household income for whites was $\$ 32,476$, compared to $\$ 18,837$ for Cambodian Americans, $\$ 14,276$ for Hmong Americans, and $\$ 23,019$ for Laotian Americans. ${ }^{98}$ As discussed below, even though past discrimination has not impacted the economic status of every individual of color to the same degree, the current system of funding campaigns poses problems because past discrimination continues to impact the economic status of many people of color.

An examination of contemporary household wealth reveals a more complete picture of the ability and likelihood to contribute or spend political money. ${ }^{99}$ While income reflects one's earnings in a particular year, wealth represents, in part, the accumulation of income over long periods of time. ${ }^{100}$ A person who earns no income but has inherited a great deal of wealth is likely to control significant resources that she may use to participate in the current campaign finance process. Further, the opportunities available due to wealth significantly shape one's future income and the income of one's offspring. Wealth reflects a type of "resource available for improving life chances, providing further opportunities, securing prestige, passing status along to one's family, and influencing the political process." 101 As shown

97. See U.S. Bureau of the Census, Money InCome in the United States: 1995, at viii (1996).

98. See U.S. Census Bureau, 1990 Census of Population, Asians and PaCifiC ISLANDERS IN THE UNITED STATES, TABLE 5, INCOME AND POVERTY STATUS OF SELECTED ASIAN AND PACIFIC ISLANDER GROUPS BY NATIVITY, CITIZENSHIP, AND YEAR OF ENTRY: 1990, at 14561 (1993), available at $\mathrm{http} / / / \mathrm{www} . c e n s u s . g o v / p r o d / c e n 1990 / \mathrm{cp} 3 / \mathrm{cp}-3-5 . p d f$.

99. See OLIVER \& SHAPIRO, supra note 82, at 58 ("“N]et worth . . . conveys the straightforward value of all assets less any debts."). While studies have not engaged in detailed analyses of whether income or wealth has the greater impact on the likelihood that an individual will make political contributions, some commentators suggest that, in certain situations, wealth has a greater impact on charitable contributions. See, e.g., Martin Feldstein, The Income Tax and Charitable Contributions, Part I-Aggregate and Distributional Effects, 28 NAT'L TAX J. 81, 90 (1975) (“At ... very high income levels, adjusted gross income is a less adequate measure of economic income and wealth is a more important influence on giving.").

100. See id. at 2 ("Wealth is what people own, while income is what people receive for work, retirement, or social welfare. Wealth signifies the command over financial resources that a family has accumulated over its lifetime along with those resources that have been inherited across generations.").

101. Id. at 32 . 
below, racial disparities in wealth are much broader than racial disparities in income. ${ }^{102}$

In 1995 , the median net worth for white households $(\$ 61,000)$ was over eight times greater than for African American households (\$7400) and over twelve times greater than for Latino households $(\$ 5000) .{ }^{103}$ Although data regarding the net worth of Asian Americans is not available, it is likely that it is lower than white Americans' net worth, as Asian Americans have a lower rate of home ownership and business ownership. ${ }^{104}$ Net worth "conveys the straightforward value of all assets less any debts," and represents financial stability. ${ }^{105}$ In the campaign finance context net worth is germane because a family with a high net worth presumably has fewer obligations and more

102. Some have asserted that net worth overlooks the value of future income, and thus income is an important component in measuring wealth. See John H. Langbein, The Twentieth-Century Revolution in Family Wealth Transmission, 86 MICH. L. REV. 722, 746 (1988) ("Because this way of measuring wealth excludes the capitalized value of the income streams generated by human capital, and because it excludes the capitalized value of private-pension and Social Security income streams, it materially overstates the disparity between the top wealth holders and the rest of the populace.”); George R. Zodrow \& Charles E. McClure, Jr., Direct Consumption Taxes, 46 TAX L. REV. 407, 483 (1991) (asserting that an "accurate measurement of wealth in practice requires accurate measurements of income"). Although "wealth and income are correlated within racial groups, . . in cross-race comparisons the wealth-income correlation breaks down almost entirely." Banks, supra note 89, at 675 n.26. Racial disparities in wealth are significant even among those who make similar incomes and have attained similar educational status. See MELVIN L. OLIVER \& THOMAS M. SHAPIRO, Race and Wealth, REV. BlACK POL. ECON., Spring 1989, at 17-18 (noting that, while the typical two-earner, black, married couple earns $77 \%$ as much as a white couple, "young white couples have nearly five times as much median [net worth] as young black couples"); OLIVER \& SHAPIRO, supra note 82, at 94 tbl. 5.1 (observing that college-educated African Americans earn $\$ 29,440$ per year, have a net worth of $\$ 17,437$, and net financial assets of only $\$ 175$, whereas college-educated whites earn on average $\$ 38,700$ per year, have a net worth of $\$ 74,922$, and net financial assets of \$19,823); Robert Westley, Many Billions Gone: Is It Time to Reconsider the Case for Black Reparations?, 40 B.C. L. REV. 429, 443 (1998) ("Poverty-level whites control nearly as many mean net financial assets as the highest-earning Blacks."); see generally MARIO BARRERA, RACE AND CLASS IN THE SOUTHWEST (1979); see also CHUCK COlLins ET AL., SHIFTING FORTUNES: THE PERILS OF THE GROWING AMERICAN WEALTH GAP 5560 (1999) (attributing racial disparities in wealth to a variety of factors, including housing discrimination, inheritance, and parental contributions to home ownership and education); CHUCK COLLINS \& FELICE YESKEL, UNITED FOR A FAIR ECONOMY, ECONOMIC APARTHEID IN AMERICA: A PRIMER ON ECONOMIC INEQUALITY \& INSECURITY 52-54 (2000) (noting that, since wealth accumulates over generations, the areas of wealth and asset accumulation demonstrate the most profound impact of racial discrimination); CONLEY, supra note 91, 142-53 (arguing that many racial inequities result from the disparities in accumulated family wealth); NATIONAL URBAN League, The StATE OF BlaCK AMERICA 1999 (William Spriggs et al. eds., 1999) (compiling statistics, charts, and essays on employment and wage gaps, health disparities, and educational levels).

103. COLLINS ET AL., supra note 102, at 55, 57 fig. 10; see also CONLEY, supra note 91, at tbl. A2.1 (finding that in 1994, the median family net worth for whites was $\$ 72,000$ and for African Americans was \$9771).

104. See Kelvin M. Pollard \& William P. O'Hare, America's Racial and Ethnic Minorities, 54 POPUlATION BUll. NO. 3, Sept. 1999, at 37-39, available at http://www.prb.org/pubs/ population_bulletin/bu54-3/Income_Wealth_Poverty.htm.

105. OLIVER \& SHAPIRO, supra note 82, at 58. 
disposable resources to spend on politics. ${ }^{106}$ Some studies suggest that racial disparities in net worth are growing. ${ }^{107}$

Even more glaring racial disparities come to light when one examines financial wealth, which is net worth minus equity in owner-occupied housing. ${ }^{108}$ Because it is unlikely that an individual will sell or mortgage the home in which she lives in order to make a political contribution, financial wealth may be even more relevant than net worth in the campaign finance context. $^{109}$ In 1995, financial wealth was $\$ 18,000$ for the typical white

106. Net worth and net financial assets are two possible ways to measure wealth. Net worth is distinguishable from net financial assets, which are "those financial assets normally available for present or future conversion into ready cash." See OLIVER \& SHAPIRO, supra note 82, at 60. Unlike net worth, a measurement of net financial assets does not take into account debt. Net worth is a better measurement of a family's ability to make political contributions and expenditures, and likelihood of making them, because a family with high net financial assets might have a number of other financial obligations, and thus have less disposable income to spend on politics. Note, however, that net financial assets represent a household's command over resources that it can use, if necessary, to improve its position. See id. Therefore, a measurement of net financial assets might reflect the amount a household could spend on politics in response to a crucial issue that they needed to address. For the purposes of this Article, however, net worth is a more appropriate measure of wealth.

107. See Blacks' Net Worth Slips, Sun REPORTER, Feb. 24, 2000, at 1 ("Blacks are tumbling backwards. The net worth of the median Black household in the U.S. fell by 17 percent to $\$ 7,000$ between the years 1994 to 1999 , according to a national survey conducted by the Panel Study of Income Dynamics. . . . During the same period the net worth of the median U.S. household rose by 9 percent to $\$ 59,000$ as the median net worth for white households reached $\$ 84,400 \ldots$. . [F]or every dollar of wealth the median white household held in 1999, the median Black household held nine cents.").

Others have predicted that the purchasing power of minority communities will increase in the near future. (Note, however, that increased spending is not necessarily related to increased wealth, and may lead to decreased wealth). See Robert Dominguez, Financial Futures; Hispanics and Wall Street, HisPANIC, Jan. 1, 1999, at 38 ("Latinos . . . will be the nation's largest minority by the year $2010 \ldots$. . [T] he community's buying power is presently worth more than $\$ 350$ billion a year and growing at a faster rate than that of Americans as a whole."); see also id. ("[T]he growth in Hispanic spending is predicted to almost double within the next five years (a 93 percent jump, compared to a projected 13 percent increase for the general population, according to Trends Research Institute in Rhinebeck, New York).”).

108. See COLlinS ET AL., supra note 102, at 55, 57 fig. 10 (discussing financial wealth (net worth minus equity in owner-occupied housing)); OLIVER \& SHAPIRO, supra note 82, at 58 ("[W]e decided to measure wealth by way of two concepts. The first, net worth (NW) conveys the straightforward value of all assets less any debts. The second, net financial assets (NFA), excludes equity accrued in a home or vehicle from the calculation of a households [sic] available resources.").

109. Even though financial wealth (net worth minus equity in owner-occupied housing) is very important in the analysis of racial disparities in the campaign finance context, home ownership is important not only because it explains net worth but also because it helps explain the financial wealth and income of future generations that control political money. In other words, even though one may not live in her parents' home, the fact that the parents owned a home may positively affect that person. Intergenerational transfers of wealth that home ownership allows (e.g., taking out a mortgage to help one with college, bequeathing assets derived from the liquidation of the home) increase one's financial wealth and income, and make one better positioned to make political contributions and expenditures. 
household, $\$ 200$ for the typical African American household, and $\$ 0$ for the typical Latino household. ${ }^{110}$

People of color are also less likely to control business interests, which accounted for \$208 million (eighty-one percent) of the "soft money" contributions made in 1999 and the first half of 2000. ${ }^{111}$ As of the mid1990s, minorities represented only three percent of senior managers of Fortune 1000 companies, ${ }^{112}$ and only four percent of directors serving on corporate boards. ${ }^{113}$ Indeed, prior to 1999, no African American had ever served as a chief executive officer of a Fortune 500 Company. ${ }^{114}$

Similarly, African Americans, Latinos, Asian Americans, and Native Americans are disproportionately represented among those Americans having the direst financial conditions. Whereas only $7.7 \%$ of whites live in poverty, $23.6 \%$ of African Americans, 22.8\% of Latinos, and $25.9 \%$ of Native Americans live in poverty. ${ }^{115}$ Even though the median income for Asian Americans as a group is twelve percent higher than whites, the poverty

110. COLLINS ET AL., supra note 102, at 55, 57 fig. 10; CONLEY, supra note 91, at tbl. A2.1.

111. See Susan Schmidt, 'Soft Money' Contributions to Parties Hit \$256 Million, WASH. PoST, Sept. 8, 2000, at A7, 2000 WL 25414744 ("Although labor unions dramatically increased their soft money giving, to $\$ 16$ million, more than triple their 1996 donations - they were dramatically outspent by business interests, which contributed $\$ 208$ million, more than 12 times the amount given by labor."). The Bipartisan Campaign Reform Act of 2002 bans soft money gifts after November 6, 2002. Bipartisan Campaign Reform Act of 2002, Pub. L. No. 107-155, § 101, 116 Stat. 81 (2002).

112. See Federal Glass CeIling Commission, GoOd For Business: MAKing Full Use of THE NATION'S HUMAN CAPITAL, at iii (1995) (finding that "97\% of the senior managers of Fortune 1000 industrial and Fortune 500 companies are white").

113. See Shelley Donald Coolidge, For Most Minorities, Heads Still Bump the Glass Ceiling, Christian SCI. MONITOR, Nov. 18, 1996, at 3, 1996 WL 5045620 (“A nationwide survey released during the summer buttresses the government report. Coopers \& Lybrand found a slight increase in the numbers of minorities serving on corporate boards of directors, from 2 percent in 1994 to 4 percent now. Hispanics and Asians are at 1 percent each.”); Tamar Jacoby, In Asian America, COMMENTARY, July 1, 2000, at 21 (observing that "of the 7,000 seats on the boards of the Fortune 500 companies, fewer than 50-less than 1 percent - are held by Asian-Americans").

114. See Edward Robinson \& Jonathan Hickman, The Diversity Elite, FORTUNE, July 19, 1999, at 62 ("In January, Chairman and CEO Franklin Raines became the first black to head a Fortune 500 company."); Heather Harris, The Perceived Influence of Culture and Ethnicity on the Communicative Dynamics of the United Nations Secretariat, BuS. COMM. Q., June 1, 2001, at 105, 106 ("Before Raines, no member of a co-cultural group, outside of European Americans, had ever been CEO of a Fortune 500 corporation."); Christine Y. Chen \& Jonathan Hickman, America's 50 Best Companies for Minorities, FORTUNE, July 10, 2000, at 190 (observing that Avon CEO “Andrea Jung . . . is the first and only minority female to hold that title in the FORTUNE 500").

115. See U.S. BuREAU OF THE Census, POVERTY IN THE UNited STATES: 1999, at v (2000), available at http://www.census.gov/prod/2000pubs/p60-210.pdf; Naomi Mezey, The Distribution of Wealth, Sovereignty, and Culture Through Indian Gaming, 48 STAN. L. REV. 711, 714 (1996) ("“American Indian reservations are notable for their extreme and persistent poverty-reservation Indians are the poorest minority in the United States. . . . [I]n some tribes, such as the Navajo, more than 45 percent of families live in poverty.") (citing Stephen Cornell \& Joseph P. Kalt, Where's the Glue? Institutional Bases of American Indian Economic Development, MALCOLM WIENER CTR. FOR SOCIAL POLICY PRS 91-1 (Harvard Project on Am. Indian Econ. Dev., Report No. 52, 1991)). 
rate of Asian Americans is fifty percent greater than whites. ${ }^{116}$ In 1995 , only fifteen percent of white households had a zero or negative net worth (greater debt than assets), compared with thirty-one percent of African American and thirty-eight percent of Latino households. ${ }^{117}$

The aforementioned data should not suggest that racial inequality can be measured with straightforward, mathematical precision. A number of complicating factors exist. For example, some citizens of color migrated to the United States after discriminatory laws were repealed. Government policies have attempted to recruit well-educated and highly skilled foreign-born workers, including people of color. ${ }^{118}$ The adverse impact of discriminatory laws is more attenuated for some individuals of color than for others. Some people of color are wealthy, and some white individuals live in poverty. These complicating factors, however, do not detract from the proposition that under the current campaign finance system, many people of color are disadvantaged due to past discriminatory laws that have shaped the existing distribution of resources. ${ }^{119}$ A precise measurement of past racial discrimination might be appropriate when analyzing issues such as government allocation of reparation payments, but such precision is not necessary when deciding whether courts should rely on the distribution of private property as an adequate baseline for political participation.

\section{People of Color Make Fewer Financial Contributions}

It should come as no surprise that demographic profiles of political contributors reflect racial disparities in the control over economic resources. $^{120}$ A 1997 study directed by scholars at Georgetown University,

116. See Pollard \& O'Hare, supra note 104, at 34, 41.

117. COLLINS ET AL., supra note 102, at 81 tbl. A-6; CONLEY, supra note 91 , at tb1. A2.1.

118. 8 U.S.C. $\$ 1153$ (b)(1)(A)(i) (1994) (allowing visas for priority workers who possess "extraordinary ability in the sciences, arts, education, business, or athletics"); id. § 1153 (b)(1)(C) (allowing visas for "certain multinational executives and managers"); id. § 1153(b)(2) (allowing visas for "members of the professions holding advanced degrees or aliens of exceptional ability"); see also Jung S. Hahm, American Competitiveness and Workforce Improvement Act of 1998: Balancing Economic and Labor Interests Under the New H-1B Visa Program, 85 CORNELL L. REV. 1673, 1678-79 (2000) (observing that provision of the Immigration Act of 1990 "was the result of congressional efforts to increase admissions of foreign skilled workers into the United States"); Bill Ong Hing, Messages of Exclusion to African Americans, 37 How. L.J. 237, 267 (1994) (observing that "the near tripling of occupational visas from 54,000 to 140,000 in the 1990 legislation signals the beginning of a shift in the focus of U.S. immigration law from concern with family reunification toward a policy of importing skilled workers").

119. In other words, even though past discrimination has not impacted the economic status of every individual of color to the same degree, the current system of funding campaigns poses problems because many people of color continue to be adversely impacted by past discrimination.

120. Empirical research generally focuses on broad questions of the racial identity of contributors. Studies have not engaged in a detailed analysis that compares the contributions of people of color and whites with identical economic profiles. While this issue deserves inquiry, it does not detract from the critique that the current distribution of private property has been shaped by illegitimate factors such as past state-sponsored racial discrimination and is thus an inappropriate 
the University of Akron, the University of Maryland, and the University of Rochester surveyed individuals who had contributed $\$ 200$ or more to congressional campaigns in the 1996 election cycle. ${ }^{121}$ Of those who responded to the survey, ninety-five percent identified themselves as white, and less than one percent identified themselves as people of color. ${ }^{122}$ These figures do not appear to be unusual. For example, a 1992 study of contributors to winning candidates for the Georgia legislature revealed that ninety-seven percent of contributors were white while only two percent were African American. ${ }^{123}$

Another study found that a disproportionately small number of contributions come from neighborhoods that are populated predominantly by people of color. The study, sponsored by Public Campaign, ${ }^{124}$ compared the racial composition of zip codes with zip-code data disclosed by political contributors. ${ }^{125}$ The study noted that in zip codes populated predominantly by people of color, the average per capita income was $\$ 9046 .{ }^{126}$ For every 10,000 residents in these zip codes, only eight political contributions were

baseline for the existing campaign finance system. In other words, even if Latinos with a household income over $\$ 100,000$ gave as much as whites with a household income over $\$ 100,000$, there would still be questions about the propriety of conditioning a crucial form of political participation on distributions of property shaped by past discrimination, as Latino households are three times less likely than white households to have a household income of $\$ 100,000$. While more empirical research would likely provide important insights, one does not need a mathematically precise understanding of the relationship between race and campaign finance contributions to raise questions about the legitimacy of the current campaign finance system.

121. Smaller contributions need not be reported to the Federal Election Commission. See Green et al., supra note 2, at 2. The study was based on data obtained through a 1997 mail survey of contributors randomly chosen from Federal Election Commission records. About half of those selected responded to the survey, and the conclusions of the study were based upon these 1118 usable responses; the margin or error is plus or minus $4 \%$. See id. at 12 .

122. See id. at 2 (showing that less than $1 \%$ of contributors surveyed identified themselves as people of color, whereas 95\% indicated they are white); Ellen Miller, Guess What? Political Donors Are Old, Rich, White Men, THE HILl, July 1, 1998, at 5, LEXIS, Nexis Library, HILLNW File (observing that "less than 1 percent in the Joyce survey identified themselves as people of color").

123. See John A. Clark \& John M. Bruce, CAmpaign Contributions in Georgia 7 (1994) ("In the 1990 Census, the population of Georgia was reported to be $71 \%$ white and $27 \%$ black. Our pool of respondents was just over $97 \%$ white, with only about $2 \%$ black."); Richard Whitt, 'Typical' Donor No Average Georgian, ATLANTA J. \& CONST., Dec. 14, 1994, at C2, 1994 WL 8920970 ("More than 97 percent of contributors responding to the survey were white and only 2 percent were black.... Questionnaires were mailed in August and September to 1155 contributors, with 357 initial responses.”).

124. Public Campaign is a public-interest organization that favors public financing of campaigns. See Public Campaign, The Color of Money: Campaign Contributions and RACE 2 (1998). For general information on Public Campaign and an abbreviated version of the study, see http://www.publicampaign.org.

125. See id. at 11-13. The Federal Election Commission does not require that contributors disclose their racial identity. See id. at 11. Therefore, to obtain its findings, the Public Campaign study compared Census Bureau data on racial composition of zip codes with Federal Election Commission data on contributions given by individuals in particular zip codes to federal candidates, political action committees, and political parties during the 1995-1996 election cycle. See id.

126. See id. at 37 . 
made. ${ }^{127}$ In contrast, in the average zip code, incomes were thirty-seven percent higher and individuals were three times more likely to make political contributions. ${ }^{128}$ In the twenty-six zip codes in which residents gave the most money, incomes were $408 \%$ higher and individuals were fifty-four times more likely to contribute than were those in predominantly nonwhite areas. ${ }^{129}$ Also, in comparing the twenty-six zip codes with the highest rates of giving to the 2,492 predominantly nonwhite zip codes, the study found that the 680,000 inhabitants of the former contributed more money than did the 41.3 million inhabitants of the latter. ${ }^{130}$

Minority participation is much higher in other forms of political activity that are not so closely related to control over economic resources. ${ }^{131}$ For example, even though minorities gave only about one percent of political contributions, they cast eighteen percent of the votes in the 2000 general presidential election. ${ }^{132}$ Minorities' failure to make political contributions is attributable more to a lack of resources than to a lack of desire to donate money. ${ }^{133}$

The political reality that people of color control fewer resources and do not make significant financial contributions to political campaigns are relevant to two critiques of existing campaign finance jurisprudence. First, speech markets created in the campaign finance context are not "neutral" or

127. See id.

128. See id. at $36-37$.

129. See id. at 37. Note that while Public Campaign reports that the average American zip code is $75.7 \%$ white, the twenty-six zip codes where residents gave the most money have an only slightly higher white population of 78\%. See id. at 22-23,36 (calculation based on chart). One might argue that these figures indicate that higher-end neighborhoods contain significant numbers of people of color who are making contributions. Public Campaign suggests that, instead, this data often reflects that a single zip code contains both high-contributing wealthy white neighborhoods and lowcontributing working-class neighborhoods populated predominantly by people of color. See id. at 6 .

130. See id. at 37. While racial disparities in political spending have not been studied as extensively as racial disparities in political contributions, there is no evidence that the expenditure racial disparity is any less stark than the contribution racial disparity.

131. See Henry E. Brady et al., Race, Ethnicity, and Political Participation, in ClASSIFYING BY RACE 354, 361-62 (Paul E. Peterson ed., 1995) ("When it comes to time, minority activists are not less active than their white counterparts.... The situation is different with respect to money. Among contributors, whites - who are, as we saw, slightly more likely than African Americans and considerably more likely than Latinos to make campaign donations - give substantially more than African Americans or Latinos do when they contribute."); BRADY ET AL., VOICE AND EQUALITY 233 (1995) ("When it comes to activity within a campaign, African Americans are more likely to say that they have worked in a campaign but less likely to say that they have given money.").

132. See Marjorie Connelly, Who Voted: A Portrait of American Politics, 1976-2000, N.Y. TIMES, Nov. 12, 2000, $\S 4$, at 4, available at LEXIS, News Library, NYT File. Even if reasons in addition to unequal access to wealth partially contribute to racial disparities in political giving, such as political apathy, the racial disparities in private wealth and the reasons behind those disparities still exist and invite questions about the legitimacy of the current campaign finance system.

133. See Brady et al., supra note 96, at 283 ("[T]he major determinant of giving money is having money. Years of education also matter, but neither free time nor civic skills affect monetary contributions."). 
"fair," but are based on existing property allocations that have been shaped by illegitimate factors such as past discriminatory public policies. Second, racial disparities in the existing campaign finance system exacerbate racial disparities in the future allocation of resources.

\section{Insights Gained Through the Recognition of Race}

The Reformers overlook historical, social, and economic realities related to race and campaign finance. Consequently, the Reformers suffer from some of the same shortcomings of the Formalists by failing to appreciate fully the interests of many of those disadvantaged by the current campaign finance system. Although some might assume that the Reformers' class-based analysis subsumes the concerns of people of color without raising the polarizing issue of race, the class analysis inadequately explores the causes and effects of the current system of financing democracy. ${ }^{134}$ Acknowledging racial realities highlights two important critiques of the current system. Race shows that the legal arguments used to defend a campaign finance system based on the existing distribution of wealth rely on democratic assumptions that are in no way neutral or apolitical, and that the existing system has the effect of perpetuating racial disparities in resources.

\section{A. The False Neutrality of Current Campaign Finance}

By overlooking racial realities, the Reformers fail to point out the biases inherent in narrow First Amendment applications that base political participation on private property. Acknowledging race allows the Reformers to craft better responses to attacks by First Amendment Formalists that are framed as seemingly objective and detached observations. ${ }^{135}$

Among their criticisms, the Formalists argue that Reformers overlook the content-neutrality requirement of the First Amendment ${ }^{136}$ and, by con-

134. Cf. Alan Freeman, Race and Class: The Dilemma of Liberal Reform, 90 YALE L.J. 1880, 1891-93 (1981) (reviewing DERRICK A. BELL, JR., RACE, RACISM AND AMERICAN LAW (2d ed. 1980)) (criticizing Marxist attempts to make race issues a subset of a larger class analysis).

135. Commentators have recognized the Court's failure to wrestle with important political realities in other contexts involving decisions about democracy. See, e.g., Heather K. Gerken, New Wine in Old Bottles: A Comment on Richard Hasen's and Richard Briffault's Essays on Bush v. Gore, 29 FLA. ST. U. L. REV. 407 (2001) (discussing the Court's failure, in cases reviewing the political process, to address difficult political realities related to race and poverty and questions as to the meaning of effective representation).

136. Even Reformers have picked up on this theme of neutrality, and do not consider the past misallocation of property. For example, Fiss argues:

Neutrality is indeed a requirement of the First Amendment, in the sense that it would violate the Amendment for the state to limit the expenditures of candidate A in order to further the candidacy of B because the state prefers candidate B's views. Democratic theory and the First Amendment leave the choice of candidates and their agendas entirely to the electorate. A more difficult problem arises when a general, apparently neutral law is adopted that nonetheless has the effect of favoring certain candidates over others. If the law had no other justification, objectively conceived, than an 
cerning themselves with the political interests of the poor, reduce campaign finance to special-interest politics. ${ }^{137}$ For example, Bradley Smith states:

People favor campaign finance reform either because they believe that campaign contributions are frustrating other policy positions they prefer, or because they have a preconceived notion of how politics should work.... Either way, their support for reform is based on substantive policy preferences and their goal is to silence those who disagree with those preferences. Reform is not intended to be "neutral." 138

Essentially, the Formalists distinguish between law and politics, and brand the Reformers' insights as political claims unworthy of consideration in the Formalists' more rarified First Amendment analysis. By examining race, however, the Reformers could expose the questionable political assumptions upon which the Formalists base their analysis.

By reading the First Amendment to prohibit certain restrictions on political money, Formalists assume (but generally do not explicitly state) that the existing distribution of property possesses some degree of legitimacy related to individual merit in the form of hard work, discipline, and intelligence. Once the First Amendment ensures a fair and neutral process, differences in political outcomes reflect meaningful and legitimate differences in ideas and in the talent behind those ideas. ${ }^{139}$ Unhampered by

interest in furthering one candidacy, then it would violate the principle of neutrality. But if its justification were to enhance the information available to the electorate, as indeed might be the case with expenditure limits, there would be no breach of the requisite neutrality.

Fiss, supra note 47, at 2480. See also Neuborne, supra note 35, at 1071 ("Finally, any program of reform must be relentlessly content-neutral. Even a hint of government efforts to skew the political marketplace should invalidate the plan.").

137. See, e.g., Bradley A. Smith, Money Talks: Speech, Corruption, Equality, and Campaign Finance, 86 GEO. L.J. 45, 71 (1997) (arguing that "it seems doubtful that any reform measure would pass a content neutrality test" because reforms are "proposed precisely because certain 'experts' believe that some views - which they do not like - are heard too much, and others views - which they prefer-are heard too little"); see also HERBERT E. AlEXANDER, FinANCING POLITICS: MONEY, EleCtions AND POLITICAL REFORM 15 (2d ed. 1980) ("Reform is not neutral. When the rules of the game are changed, advantages shift and institutions change ...."); BeVier, supra note 31 , at 1062 (" $[\mathrm{W}]$ hatever the motivations of their political sponsors, laws directly regulating explicitly political behavior can never have a neutral impact.... Statutes that are supported precisely because they deprive a particular group of its ability to engage relatively effectively in politics, therefore, may not be as 'entirely content neutral' as they seem."); Smith, supra note 16, at 1080 (observing that "[o]nce it is conceded that [campaign finance reform] legislation is intended to hamper the expression of some ideas and not others, it is difficult to assert that the regulation is content-neutral"); Kathleen M. Sullivan, Political Money and Freedom of Speech: A Reply to Frank Askin, 31 U.C. DAVIS L. REV. 1083, 1085 (1998) (arguing that a purpose of campaign finance reform-equalizing access and influence - is not obviously content-neutral).

138. Smith, supra note 137 , at $71 \mathrm{n} .180$.

139. $C f$. id. at 95 ("By allowing monetary contributions, all persons have the opportunity to put their personal talents to use in the political arena."). 
government-imposed restrictions, the political marketplace guarantees that political outcomes reflect the collective wisdom of the best and the brightest.

If the Formalists' vision serves as the interpretive framework through which one understands the world, an application of First Amendment doctrine to limit political-money restrictions appears to be content-neutral and apolitical. The Formalists' rhetoric seems to be nonpartisan and inclusive of all. Ignoring the relationship between past state-sponsored racial discrimination and the current distribution of property, Formalists support a system in which courts purport to give all citizens, including people of color, an equal opportunity to spend as much as they choose. ${ }^{140}$

Although they have had some rhetorical success in cloaking their arguments with the appearance of objectivity and inevitability and in characterizing the Reformers as partisans, ${ }^{141}$ Formalists rely on their own political interpretations to give meaning to their understanding of rights. ${ }^{142} \mathrm{~A}$ more comprehensive vision of the world allows for an analysis of campaign finance law against the backdrop of property allocations that have been shaped by racial discrimination. Even after the dissolution of racially discriminatory laws against people of color, the law has ratified the misallocation of property by protecting the settled expectations of those who obtained economic benefits under a discriminatory regime. ${ }^{143}$ Legal protection of those settled expectations, along with doctrines that build upon existing property rights (such as the First Amendment applications promoted by the Formalists), obscure continued privilege based on past discriminatory practices and make the existing economic order appear fair and equal. ${ }^{144}$

140. Cf. Rhonda M. Williams \& William E. Spriggs, How Does It Feel to be Free?: Reflections on Black-White Inequality in the Era of "Color-Blind" Law, 27 REV. BLACK POL. ECON., Summer 1999, at 9, 10 ("Formal equality requires only ... procedural equality.... Like many human capital theorists, today's judges lean toward the assumption that discrimination is not a significant social relation. Whatever role racism and discrimination have played historically in allocating the resources social competitors now bring to the game is none of the Courts' business.").

141. Cf. Kimberlé Williams Crenshaw, Race, Reform, and Retrenchment: Transformation and Legitimization in Antidiscrimination Law, 101 HARV. L. REV. 1331, 1351 (1988) ("The concept of hegemony allows Critical scholars to explain the continued legitimacy of American society by revealing how legal consciousness induces people to accept or consent to their own oppression."); see also id. at 1370 ("Throughout American history, the subordination of Blacks was rationalized by a series of stereotypes and beliefs that made their conditions appear logical and natural.").

142. See Mark Tushnet, An Essay on Rights, 62 TEXAS L. REV. 1363, 1363-64 (1984) (arguing that rights are unstable, produce indeterminate consequences, falsely convert valuable experiences into empty abstraction, and impede advances by progressive social forces).

143. See Harris, supra note 79, at 1714 ("After legalized segregation was overturned, whiteness as property evolved into a more modern form through the law's ratification of the settled expectations of relative white privilege as a legitimate and natural baseline."). In some situations, however, courts refuse to protect or ratify expectations in property acquired under a discriminatory regime. See, e.g., Shelley v. Kraemer, 334 U.S. 1, 4 (1948) (invalidating judicial enforcement of racially restrictive covenants).

144. See Harris, supra note 79, at 1777 ("The law masks what is chosen as natural; it obscures the consequences of social selection as inevitable. The result is that the distortions in social 
Spending and contributing political money are not prepolitical or natural liberties but are, instead, parasitic on positive law, including state-sponsored discrimination. ${ }^{145}$ Although courts developed the content-neutrality requirement as a judicial tool in interpreting the First Amendment to prevent the evil of viewpoint discrimination, ${ }^{146}$ Formalist arguments that base campaign finance on the existing distribution of property advance the political ideologies of those who have profited from the discriminatory misallocation of property. ${ }^{147}$ Past state-created advantages tend to allow individuals with certain racial backgrounds to obtain an unfair advantage in the political marketplace. ${ }^{148}$

The Formalists may deny the relevance of race in defending their claim to objectivity and neutrality, but denials make their arguments no less political. Some Formalists may contend that racial disparities in property holdings reflect a coincidental distribution based on individual merit and that it is thus fair to construct a campaign finance system based on private property. Another group may claim that no manageable method of

relations are immunized from truly effective intervention, because the existing inequities are obscured and rendered nearly invisible."); William Patton \& Randall Bartlett, Corporate "Persons" and Freedom of Speech: The Political Impact of Legal Mythology, 1981 WIS. L. REV. 494, 510 (stating that law is "not given the luxury of adopting a position which has no political consequences").

145. Frank I. Michelman, Process and Property in Constitutional Theory, 30 CLEV. ST. L. REV. 577,586 (1982) (observing that "the constitutional right of property is strictly parasitic on nonconstitutional positive law"). In short, the Formalists constitutionalize rights that arise from laws that we would today consider unconstitutional.

146. See Daniel A. Farber, Content Regulation and the First Amendment: A Revisionist View, 68 GEO. L.J. 727, 735 (1980) ("Viewpoint-based discrimination is more clearly troublesome than subject-matter discrimination."); Geoffrey R. Stone, Restrictions of Speech Because of its Content: The Peculiar Case of Subject-Matter Restrictions, 46 U. CHI. L. REV. 81, 108 (1978) (“[T]he Court's rigorous approach to content-based restrictions stems in part from the realization that such restrictions have an especially potent content-differential impact upon the 'marketplace of ideas.'... Although not without difficulties, viewpoint-neutral restrictions directed against all speech relating to an entire subject do not have the same sort of skewing effect on 'the thinking process of the community' as restrictions directed specifically against speech taking a particular side in an ongoing debate.”); J. Skelly Wright, Politics and the Constitution: Is Money Speech?, 85 YALE L.J. 1001, 1009 (1976) ("The main evil against which rigorous First Amendment scrutiny is designed to guard is content discrimination-discrimination based on the message itself."); $c f$. Richard H. Fallon, Jr., The Supreme Court, 1996 Term-Foreword: Implementing The Constitution, 111 HARV. L. REV. 54, 67-75 (1997) (describing various tests used by the Court in interpreting constitutional doctrine).

147. Cf. Johnson, supra note 80, at 529 n.20 ("Although the most invidious discrimination in the naturalization laws has been removed, the legacy of exclusion must be examined to ensure that its discriminatory influence can be extracted root and branch.'); Eric Schnapper, Perpetuation of Past Discrimination, 96 HARV. L. REV. 828 (1983) (explaining how past discrimination causes present injury and examining legal approaches aimed at preventing the perpetuation of racism).

148. Cf. Austin v. Mich. Chamber of Commerce, 494 U.S. 652, 658-59 (1990) (citing FEC v. Mass. Citizens for Life, Inc., 479 U.S. 238, 257 (1986)) (permitting restrictions on corporate expenditures in support of political candidates, reasoning that the state gives corporations special advantages in accumulating resources, and that these "state-created advantages" allow corporations "to use 'resources amassed in the economic marketplace' to obtain 'an unfair advantage in the political marketplace"”). 
accounting for the impact of past racial wrongs exists. Thus, that group may choose to tolerate the status quo not only in the economic marketplace but also with regard to democratic participation under the current campaign finance system. Others assert that proposed reforms will fail to address the problems of the existing system and will likely cause new problems. ${ }^{149}$ Some important scholars articulate these perspectives, and their insights should not be casually dismissed in making political judgments about campaign finance regulation. Nevertheless, there is no apolitical, determinate organizing principle that mandates that society as a whole adopt these judgments to the exclusion of the historical and continuing relationship between race and private property. ${ }^{150}$ While supporters of a privately financed political system with minimal regulation may specify a vision of the world that tolerates the protection of participatory rights acquired due to past discriminatory policies, others should not be forced to embrace this normative interpretation.

One problem with current jurisprudence, however, is that it limits the political understandings of the role of property by extending high constitutional protection to property used in the campaign finance context. ${ }^{151}$ While property rights shaped by racial discrimination are generally subject to legislative restriction and redistribution in the economic sphere, ${ }^{152}$ these same property rights are more absolute and impenetrable when exercised in the political context. ${ }^{153}$ Current campaign finance jurisprudence strictly protects

149. See Issacharoff \& Karlan, supra note 12, at 1707 (arguing that "[reform] proposals may increase, rather than dampen, the role of money in politics" and make politics less accountable to democratic control). But cf. Daniel Hays Lowenstein, On Campaign Finance Reform: The Root of All Evil Is Deeply Rooted, 18 HOFSTRA L. REV. 301, 303-04 (1989) (arguing that opponents of reform have little empirical evidence to support their proposition that reforms "are far more likely to be harmful than beneficial," and that there may be unanticipated consequences of maintaining the status quo).

150. Cf. Crenshaw, supra note 141, at 1346 ("[L]aw itself does not dictate which of various visions will be adopted as an interpretive base. The choice between various visions and the values that lie within them is not guided by any determinate organizing principle.").

151. See Nixon v. Shrink Mo. Gov't PAC, 528 U.S. 377, 386-88 (2000) (interpreting the appropriate standard for reviewing contribution limits as more stringent than intermediate scrutiny but "different" from the strict scrutiny applied to expenditure limits).

152. See, e.g., Minnesota v. Clover Leaf Creamery Co., 449 U.S. 456, 466 (1981) (upholding environmental regulations); West Coast Hotel Co. v. Parrish, 300 U.S. 379, 399 (1937) (allowing for legislative regulation of minimum wage); Euclid v. Ambler Realty Co., 272 U.S. 365, 388-90 (1926) (allowing for legislative zoning); Block v. Hirsh, 256 U.S. 135, 156 (1921) (allowing for legislative rent control); Nat'l Cotton Oil Co. v. Texas, 197 U.S. 115, 129 (1905) (allowing for legislative antitrust regulation).

153. $C f$. JENNIFER NEDElsky, PRIVATE PROPERTY AND THE LIMITS OF AMERICAN CONSTITUTIONALISM: THE MADISONIAN FRAMEWORK AND ITS LEGACY 260 (1990) ("Why give up the overt formal limits [on the legislature] with respect to economic regulation and social assistance, and enforce the power and privilege of property against the egalitarian measures of campaign finance laws?"); Frank Michelman, Political Truth and the Rule of Law, 8 TEL AVIV U. STUD. IN LAW 281, 288 (1988) (asking why realism and relativism "have been such potent destroyers of juristic absolutism shielding the market manifestations of property rights against legislative control, but so impotent...when it comes to their manifestations in the political 
the settled expectations of those who have benefited from illegitimate distributions of property and generally ignores those disadvantaged by illegitimate distributions. ${ }^{154}$

The disparate judicial treatment of property in the economic and political spheres is made even more troubling by the fact that racial disparities are generally more tolerable in the economic sphere than the political sphere. ${ }^{155}$ While statutes prohibit racial discrimination in housing, employment, and other economic aspects of life, the law often tolerates racial disparities in these areas. ${ }^{156}$ Some commentators make seemingly persuasive arguments that economic markets should reward individual compliance with purportedly neutral merit-based criteria, regardless of context, history, and racial impact. ${ }^{157}$ In contrast, racial inclusion is affirmatively mandated in the political sphere by doctrines surrounding the Fifteenth Amendment and the Voting Rights Act. ${ }^{158}$ With regard to democratic exchange and governance, the need for commitment from a diverse, broad base of perspectives suggests that, to the greatest extent possible, we should prevent the effects of past state-sponsored discrimination from suppressing political participation. ${ }^{159}$ While one might cite concerns about institutional competence to defend

sphere"); Frank I. Michelman, Possession vs. Distribution in the Constitutional Idea of Property, 72 IOWA L. REV. 1319, 1344-45 (1987) ("Why have realism and relativity been such potent destroyers of juristic absolutism regarding legislative control of the market manifestations of possessive property rights, while absolutism still shields their manifestations in the political sphere?").

154. See Buckley v. Valeo, 424 U.S. 1, 54 (1976) ("The ancillary interest in equalizing the relative financial resources... is clearly not sufficient to justify the ... infringement of fundamental First Amendment rights.").

155. Cf. Roy A. Schotland, Proposals for Campaign Finance Reform: An Article Dedicated to Being Less Dull Than Its Title, 21 CAP. U. L. REV. 429, 435 (1992) (observing that a commitment to political equality coexists with acceptance of economic inequality).

156. Cf. Spencer Overton, Voices from the Past: Race, Privilege, and Campaign Finance, 79 N.C. L. REV. 1541, 1545-51 (2001) (discussing the law's tolerance for economic disparities caused by prior racial discrimination).

157. See generally Shelby Steele, The Content of Our Character: A NeW Vision of RACE IN AMERICA (1990) (criticizing affirmative-action programs); STEPHAN THERNSTROM \& Abigail Thernstrom, AmERICA IN Black AND White: ONE NATION, INDIVISIBLE (1997) (same).

158. See infra subpart V(A) (explaining that the Voting Rights Act fails to resolve all problems regarding race and campaign finance, but that the text and doctrine surrounding the statute are important in principle).

159. $C f$. Abigail Thernstrom, WhOSE Votes COUNT? 242 (1987) (admitting that "[a] white denied a seat on a city council cannot claim entitlement on the ground of "merit"' and that "qualification for office is not measured by meritocratic standards in the customary sense"); Pamela S. Karlan \& Daryl J. Levinson, Why Voting Is Different, 84 CAL. L. REV. 1201, 1202 (1996) (arguing that "the Court's attempt to integrate voting rights law into its more general approach to affirmative action is both misguided and incoherent" because "government decisionmaking with respect to voting, at least in its functional sense of rationing and apportioning the power to govern, is different from other governmental decisionmaking"); James Thomas Tucker, Affirmative Action and Misrepresentation (pt. 2), 43 How. L.J. 405, 454-55 (2000) (criticizing the merit-based approach as applied to voting, distinguishing redistricting from employment, contracting, and college-admissions decisions). 
judicial failure to mandate the elimination of campaign finance practices that disadvantage people of color, affirmative judicial obstruction of legislative actions that minimize such disadvantages raises serious questions. ${ }^{160}$

\section{B. Future Perpetuation of Racial Disparities}

By failing to acknowledge relevant racial realities, the Reformers miss a second critique: namely, that the existing campaign finance system perpetuates racial disparities in the political distribution of societal resources. In their class-based analyses, some Reformers point out that a primary role of the democratic decisionmaking process is to determine how wealth should be allocated. ${ }^{161}$ According to these commentators, the current campaign finance system gives wealthier individuals advantages in influencing democratic decisions regarding future allocations of wealth, ${ }^{162}$ thereby reinforcing the power of the affluent and the powerlessness of the poor. ${ }^{163}$ A more complete critique would observe that the existing campaign finance system not only solidifies the current class structure but also entrenches the economic status of particular racial groups within the current class structure.

Race theorists have noted that legal doctrine helps to perpetuate racial hierarchy by protecting settled expectations shaped by a history of discrimination. ${ }^{164}$ Other race commentators have extended this critique by

160. Cf. Sylvia R. Lazos Vargas, Democracy and Inclusion: Reconceptualizing the Role of the Judge in a Pluralist Society, 58 MD. L. REV. 150, 159 (1999) (asserting that the Court often privileges one epistemological framework over others in constructing its interpretation of the world, and calling on the Court both to employ other frameworks and to limit "its intrusions into the political sphere").

161. See Foley, supra note 36, at 1243 ("[N]o citizen has a valid claim to private property for the specific purpose of participating in the electoral process-because the electoral process itself determines the validity of all claims to private property.").

162. See id. at 1204 ("An important function of electoral politics is to determine how wealth should be distributed among society's members. The existing distribution of wealth at the time of any particular election should not affect the electorate's determination of what the distribution should be henceforth.").

163. Reformers point out that "private campaign money is a principal means of reinforcing the powerlessness of less affluent citizens." Raskin \& Bonifaz, Constitutional Imperative, supra note 37, at 1182; see also Raskin \& Bonifaz, Equal Protection, supra note 37, at 301 ("The systemic degradation of the political influence of the nonaffluent is best witnessed by government policy. Congress is far more responsive to the political interests of the wealthy than the poor, and often acts to the detriment of those who do not participate in the wealth primary. As political campaign costs and expenditures have soared in the last two decades, poor and working-class people have steadily lost economic ground, while wealthy individuals and corporations have been greatly enriched."); NEDELSKY, supra note 153, at 260 ("Why ... enforce the power and privilege of property against the egalitarian measures of campaign finance laws? Perhaps the answers lie in what is actually a serious threat to that power and privilege."). The author has also examined economic entrenchment in the campaign finance context without discussing racial implications. See Spencer Overton, Mistaken Identity: Unveiling the Property Characteristics of Political Money, 53 VAND. L. REV. 1235, 1274-80 (2000).

164. See Crenshaw, supra note 141, at 1383 ("The race neutrality of the legal system creates the illusion that racism is no longer the primary factor responsible for the condition of the Black 
observing that racial subjugation, even in the absence of race-conscious discrimination, is affirmatively exacerbated by structural phenomena, such as residential segregation and mortgage-lending decisions. ${ }^{165}$ The existing campaign finance system is another structural device that works to perpetuate racial disparities. Privately financed politics, framed by a history of facially discriminatory laws that have contributed to a present-day disparity in control over resources, reproduce and exacerbate racial disparities in the distribution of resources and political influence. These increasing disparities, combined with numerical minority status, make people of color especially vulnerable in the current political system.

1. Entrenching Inequality in the Absence of Discrimination.-Even in a world in which conscious racism against African Americans, Asian Americans, Latinos, and Native Americans has been eliminated, a privately financed political system perpetuates racial subjugation. Political and economic disadvantages persist despite the lack of formal prohibitions on the right of people of color to vote or contribute money. Also, donors and politicians may act in a colorblind fashion yet perpetuate a process that systematically dilutes the economic and political influence of people of color.

For example, envision a hypothetical society comprised of two groups, the Whites and the Browns. ${ }^{166}$ The Whites comprise a majority of the

underclass. ..."); Harris, supra note 79, at 1778 ("The property interest in whiteness ... has ... continued to distort outcomes of legal disputes by favoring and protecting settled expectations of white privilege. The law expresses the dominant conception of 'rights,' 'equality,' 'property,' 'neutrality,' and 'power': rights mean shields from interference; equality means formal equality; property means the settled expectations that are to be protected; neutrality means the existing distribution, which is natural; and, power is the mechanism for guarding all of this.").

165. See Banks, supra note 89, at 689-90 (arguing that "[b]ecause of historical discrimination, current racial disparities in mortgage lending and other areas could continue even in the complete absence of current discrimination"); Ford, supra note 84, at 1848 . Indeed, just as suburban communities are often racially segregated, exclusionary spaces that offer more extensive devices to protect the wealth of residents (e.g., greater educational opportunities, zoning designed to maintain property values), fundraising receptions are often racially segregated, exclusionary spaces that allow contributors to protect their wealth through access to government decisionmakers. See id. at 1847 (" $[\mathrm{R}]$ esidential segregation and ... the geographic boundaries that define local governments ... are not the only examples of racially identified space, [but] they are so intimately linked to issues of political and economic access that they are among the most important.").

166. See Ford, supra note 84, at 1849-52 (using a similar hypothetical to show the selfsustaining nature of racial segregation in housing). Some commentators reject group interests and rights, while others consider group association to be an essential component of individual political participation. Compare Katherine Inglis Butler, Affirmative Racial Gerrymandering: Fair Representation for Minorities or a Dangerous Recognition of Group Rights?, 26 RUTGERS L.J. 595, 621 n.72 (1995) ("Once we recognize that racial groups are entitled to be represented as racial groups, we are well on our way to enthroning group fairness, rather than individual merit, as the basis for all societal decisions.”), with Davis v. Bandemer, 478 U.S. 109, 167 (1986) (Powell, J., concurring in part and dissenting in part) ("The concept of 'representation' necessarily applies to groups: groups of voters elect representatives, individual voters do not."). Although this Article does not embrace either position as a normative goal, it recognizes that groups exist in politics as a descriptive matter; my purpose here is to examine the effect of a privately financed campaign 
society's population, and the Browns constitute a minority. Due to historical discrimination in the hypothetical society, Browns generally control less wealth and earn less than Whites do. The society recently realized that racial discrimination was wrong and has enacted a successful public education program that convinces all of its citizens of the impropriety of discrimination. While all of the citizens are now colorblind, one must also assume that most remain concerned about their own financial security and that they will act accordingly. Consequently, political decisions will tend to favor the economic interests of predominantly White political communities that can afford to contribute money (for example, by enacting lower inheritance taxes, allowing tax deductions for business lunches, and basing educational funding on revenue from local property taxes). At the same time, due to the inability of the Browns to participate in the current campaign finance system, it is probable that future lawmaking will steer finite societal resources and opportunities away from them.

An argument that this is simply a "class" problem and that, over time, wealth disparities will even out between the Brown and White communities is flawed. An assumption that members of Brown communities will start supporting particular policies in the same proportion as the White political community once wealth disparities even out relies on the belief that wealth disparities will naturally disappear on their own. Due to privately financed politics, however, past racial distributions of wealth will impact present racial distributions of wealth, and present distributions will impact future distributions. Every generation would be influenced by the racial disparities of previous generations, even though this structure can be described without using the term "racism."

The fact that such racially disparate allocations of property could flow from decisions made with a complete disregard for race confirms the proposition that privately financed politics reaffirms past racially discriminatory public and private decisions. The campaign finance system allows racial subordination to take on a life of its own.

\section{Entrenching Inequality in a Political System Influenced by Racial} Identity.-Imagine inserting a few real-world difficulties into the hypothetical. Perhaps racial group identity is a significant part of political activity; just as racial bloc voting exists, racial bloc contributing exists. ${ }^{167}$

system on the shared political interests of individuals who have been disadvantaged by past discrimination. $C f$. FRANK MICHELMAN, BRENNAN ON DEMOCRACY 123 (1999) (asserting that a consideration of fact (as perceived) about "the communal bases of individual identities ... does not in any way contradict ... normative individualism").

167. See John Theilmann \& Al Wilhite, Discrimination and Congressional CAMPAIGN CONTRIBUTIONS 78 (1991). The authors contend: 
Under such a scenario, ninety percent of White contributors give only to White candidates, and ninety-five percent of Brown contributors give only to Brown candidates. ${ }^{168}$ Because Whites have more money, give larger contributions, and are twenty-five times more likely to give money than are Browns, White candidates receive many more contributions than Brown candidates do. ${ }^{169}$ Also, imagine that many electoral districts are based on municipal boundaries and that the municipalities are, due to historical factors, racially segregated. ${ }^{170}$ An overwhelming majority of Brown candidates run in these predominantly Brown districts. The donations White contributors give to Brown candidates are overwhelmingly directed to incumbents. ${ }^{171}$

Under these conditions, the campaign finance system would affect the participation of Brown citizens even more adversely. It is likely that because of the financial dominance of the White donors, their contributions will form a large majority of the money received by the Brown incumbents, despite the fact that most contributions from Whites continue to go to Whites. ${ }^{172}$ Brown incumbents from Brown districts will face insignificant challenges from underfunded insurgents - who will usually be Browns - in either primary or

[T] here does seem to be a pattern of racial discrimination in the allocation of total campaign contributions. After controlling for attributes such as candidate strength, opposition strength, party affiliation, and the incumbency advantage, black candidates received substantially lower levels of funds than did nonblack candidates. Because the primary determinants of candidates' fund-raising abilities are included in the analysis, the differential appears to be racially motivated.

Id.

168. Cf. Vecinos de Barrio Uno v. City of Holyoke, 960 F. Supp. 515, 519 (D. Mass. 1997) (noting that Hispanic candidates frequently ranked first in preference among Hispanic voters but ranked much lower among non-Hispanic white voters, who preferred white candidates); Smith v. Clinton, 687 F. Supp. 1310, 1315 (E.D. Ark. 1988) (observing that in the 1988 primary election for the state legislature, almost $100 \%$ of African American voters supported the African American candidate, while $93 \%$ of white voters supported the white candidate).

169. $C f$. THEILMANN \& Wilhite, supra note 167, at 152-53 (finding that African American candidates generally received significantly less money from large individual contributions (those greater than \$500) and African American incumbents typically received less money from political action committees, resulting in African American candidates' receiving from " $\$ 7,000$ to almost $\$ 30,000$ less through the 1980 s").

170. $C f$. U.S. CENSUS BuREAU, StATISTICAl BRIEF: Poverty AREAS 1 (1995), available at http://www.census.gov/population/socdemo/statbriefs/povarea.html (observing that "[f]our times as many Blacks and three times as many Hispanics lived in poverty areas than lived outside them").

171. Cf. Robert C. Smith, Financing Black Politics: A Study of Congressional Elections, 17 REV. OF BLACK POL. ECON., Summer 1988, 5, 24 (1988) (observing that "it is clear that whites rarely wish to support black challengers in black congressional elections").

172. Id. ("Congressional elections in the black community tend to be financed largely by white dominated PACs and disproportionately by large (probably white) contributors ....”); ROBERT Singh, The Congressional Black CAUCus: RaCial Politics IN THE U.S. CONGRESS 125-26 (1998) ("The funding of black campaigns remains substantially the province of political actors external to black communities. ... Without exception, over every congressional election cycle, $\mathrm{CBC}$ members raise more funds from PACs alone than their challengers raise from all sources combined."). 
general elections. ${ }^{173}$ Because of this trend, little democratic dialogue about policy will take place in Brown communities. ${ }^{174}$ White contributors will fund incumbents from both predominantly White and predominantly Brown districts, and Brown communities will lack similar connections to any incumbents. Due to the geographic segregation, many government decisions - such as localized education with funding based on municipal boundaries - will have an even more substantial impact on the distribution of resources. Also, because Brown incumbents, like other politicians, have an interest in being reelected, only a few will seriously attempt to disrupt the existing allocation of resources and threaten the contribution stream that gives them an advantage over challengers. ${ }^{175}$

\section{Private Money Is Most Harmful to "Discrete and Insular"} Minorities.-The cycle described above, in which the existing campaign finance system perpetuates racial disparities in economic resources, constitutes a failure of the political process even more troubling than the failure described by the Reformers. Many Reformers criticize the existing campaign finance system as a flawed process that allows an upper-class minority to abuse the interests of lower- and middle-class majorities. ${ }^{176} \mathrm{In}$ the form of a "Carolene Products/John Hart Ely" critique, some observe "that the political process itself is flawed or defective when large sums of money can be used to influence legislators under the guise of freedom of association, or influence voters under the guise of freedom of speech."177

173. Cf. SiNGH, supra note 172, at 125 (noting that "[i]n 1994, the average challenger to a CBC incumbent spent $23.8 \%$ of the amount spent by the incumbent"); Smith, supra note 171, at 16 ("It appears that the financial and other advantages of incumbency (name recognition, constituency service, media access, etc.), the relatively small stratum of politically active citizens in the districts, the relatively low income status of black voters, the one-party dominance in the districts and the disproportionate dependence of black congressional campaigns on externally generated PAC money operate to create near permanency of tenure for black members of Congress.").

174. Cf. Smith, supra note 171 , at 25 (Recognizing that the "tendency of campaign contributors to discriminate against challengers ... puts a burden on the black community because it is deprived of a robust, competitive debate in its politics").

175. But cf. SINGH, supra note 172, at 129-31 (observing that due to high incumbency rates, African American representatives may be able to acquire more seniority in Congress and be more overtly partisan and radical).

176. See, e.g., Raskin \& Bonifaz, Equal Protection, supra note 37, at 277 (“[T]he tyranny of private money corrupts the democratic relationship of one person/one vote ... by assuring that wealthy interests will set the parameters of political debate and the nature of the legislative agenda. Not surprisingly, the nonaffluent majority continues to lose ground in public policy and turn away in disgust from the political system.").

177. Balkin, supra note 42, at 378 ("This line of arguments critiques the 'money as speech' position taken in cases like Buckley $v$. Valeo. It argues that regulation of campaign finance is necessary because what passes for free speech is really more like unregulated economic power that is used to influence (and corrupt) the political process." (citing United States v. Carolene Prods. Co., 304 U.S. 144, 152 n.4 (1938), and JOHN HART ELY, DEMOCRACY AND DISTRUST: A THEORY OF JUDICIAL REVIEW 105-34 (1980))). 
This phenomenon is even more pronounced, however, when one examines the interests of many racial minorities in relation to those who both control greater wealth per capita and represent a numerical majority. ${ }^{178}$ Courts and commentators have paid special attention to laws that disadvantage discrete and insular minorities in the political process. ${ }^{179}$ Democracy is said to malfunction when an effective majority-either directly or through its representatives - systematically and unfairly uses the power of government to burden or disenfranchise a political minority. ${ }^{180}$ The Formalists' application of the First Amendment in the campaign finance context is more problematic for many Browns than for many lower- and middle-class Whites in the above hypothetical for two reasons related to minority status.

First, the Browns would not be protected by the formal political defenses that buffer less wealthy racial majorities against abuses by wealthy contributors. If contributors were to go too far or be too obvious in their abuse of the White majority, then the contributors could be exposed by the press, and less wealthy Whites could self-interestedly vote against the proposals of the wealthy. Browns, on the other hand, are the numerical minority in many county, state, and federal elections, and could not use the formal vote to defend their particular interests to a similar extent. ${ }^{181}$ Granted, the vote would have limited utility for the Whites against the abuses of money due to a number of factors (including imperfect information ${ }^{182}$ and lack of meaningful choice), because all viable candidates may have received

178. Some might argue that there are only a small number of whites acting to disadvantage people of color. The fact, however, that only a minority of whites owned slaves or owned stores that would not cater to people of color does not make the discriminatory effect any less pronounced.

179. See Carolene Prods., 304 U.S. at 152 n.4; ELY, supra note 177, at 105-34; cf. Foley, supra note 36, at 1222 ("Now, the rich may argue that they need extra voting rights to protect their greater wealth from the self-interested designs of the poor but that the poor need less protection because they have so much less to lose. This argument, however, must fail because it presumes that the rich are entitled to protect their wealth against redistributivist efforts by the poor (and the middle class). Whether the rich have a valid claim to the wealth they possess is precisely the issue to be decided by the decision-making process.").

180. Ely, supra note 177, at 103; $c f$. THE FEDERALIST NO. 10, at 80 (James Madison) (Clinton Rossiter ed., 1961) ("When a majority is included in a faction, the form of popular government ... enables it to sacrifice to its ruling passion or interest both the public good and the rights of other citizens.").

181. Cf. Owen M. Fiss, Groups and the Equal Protection Clause, 5 PHIL. \& PuB. AFF. 107, 152 (1976) (asserting that African Americans have not prospered through the American democratic process because "they are a numerical minority," have a low "economic status," and, as "discrete and insular" minorities, suffer prejudice that impairs them in forming coalitions with others).

182. See E. Joshua Rosenkranz, Faulty Assumptions in "Faulty Assumptions": A Response to Professor Smith's Critiques of Campaign Finance Reform, 30 CONN. L. REV. 867, 879-80 (1998) (arguing that legislatures consider many specialized issues that arouse little public interest). 
money from and support a particular interest of the wealthy. ${ }^{183}$ Further, if the abuse of the Browns by wealthy interests were sufficiently obvious, the Browns may be able to appeal to the moral conscience of the White majority and build a political coalition. Nevertheless, voting strength would not shield the interests of the Browns to the same degree that it would for less wealthy Whites.

Second, outside of the voting context, middle- and lower-class Whites, in part because of their sheer numbers, collectively control more resources than Browns do. While lower- and middle-class Whites could not play the money game to the same degree that wealthy Whites could, they would be able, if necessary, to draw upon more resources to defend their interests. ${ }^{184}$ Brown citizens, both because they control fewer resources per capita and because they are numerical minorities, would not be able to defend all of their interests to the same degree. For this reason, the privately financed system would adversely affect the political interests not only of impoverished Browns but also of Brown citizens who are not as impoverished. For example, some Browns might have a higher household income than Whites do, but they might make up only four percent of the population. ${ }^{185}$ Therefore, while these wealthier Browns may be able to make meaningful contributions in support of class interests shared by the wealthy of different races, the Browns may be less able to use money to advance any particular political interests they may have that are related to race. Even if the wealthier Browns gave twice as much as others, their contributions would constitute only eight percent of total contributions, ${ }^{186}$ an amount unlikely to carry great weight for real change when pitted against the overwhelming amount of contributions coming from Whites and the potential xenophobia of the general population as a whole. ${ }^{187}$

183. Cf. Raskin \& Bonifaz, Equal Protection, supra note 37, at 309 (describing the "extraordinary correlation between candidates who are wealthy primary winners and those who are general election winners").

184. These resources might manifest themselves either directly (e.g., contributions of money) or indirectly (e.g., a news program is more likely to focus on an issue that impacts a large number of people, in part because such an issue will attract more viewers and increase advertising revenues).

185. $C f$. U.S. Bureau of the Census, CurRent Population RePorts, P60-200, Money INCOME IN THE UNITED STATES: 1997 (With Separate Data on Valuation of Noncash Benefits), at ix (1998) ("Asians and Pacific Islanders continued to have the highest median household income $(\$ 45,249)$ among the race groups in 1997 . Whites had the second highest $(\$ 38,972)$ followed by Black households $(\$ 25,050)$."); U.S. BUREAU OF THE CENSUS, THE ASIAN AND PACIFIC ISLANDER POPUlATION IN THE UNITED STATES: Population CHARACTERISTICS 1 (1999) (reporting that Asian Americans make up $4 \%$ of the total U.S. population).

186. Cf. Wang, supra note 74 , at 339 ("John Huang was responsible for raising $\$ 3.5$ million, a minuscule amount when compared to the $\$ 2.2$ billion raised in the last federal elections.").

187. Note that even though some Asian Americans control significant resources, fear of enhanced scrutiny and allegations of attempts to buy influence on behalf of foreign interests may discourage Asian Americans from making contributions. See id. at 330-31 ("The media began employing terms such as the 'Asian connection' and 'Asian Americans' as synonymous with 
The minority status of the Browns would make them especially prone to mistreatment in the current political system because they have both fewer votes and fewer economic resources than others in our hypothetical society. These disadvantages would do more than increase the probability that the numerical racial majorities would unfairly use the power of government to disenfranchise the Browns. ${ }^{188}$ The disadvantages also make it more likely that wealthy, overwhelmingly White contributors would use their political money to effectuate government decisions, such as the location of toxic waste storage, in a way that burdens populations without the political tools to defend their interests. ${ }^{189}$

Some might assert that even if courts were more tolerant of legislative reforms, the Whites in our hypothetical society would not support campaign finance reform under these facts. If the current system allows Whites to obtain political decisions that favor their own economic interests, some might argue, then it is unlikely that many Whites would support campaign finance reform that would mitigate the political advantages they enjoy over the Browns. ${ }^{190}$ Such a result is possible, but the mere possibility of inaction should not obstruct the alteration of current jurisprudence for a number of reasons. First, as with civil-rights legislation following Brown v. Board of

political corruption and foreign subversion of the political process, even though Huang and Trie raised only about $\$ 4.5$ million out of the total of $\$ 2.2$ billion raised in the 1996 federal elections."); James Sterngold, For Asian-Americans, A New Political Resolve, N.Y. TIMES, Sept. 22, 1999, at A1, LEXIS, Nexis Library, NYT File (observing that "many Asian-Americans feel that the fundraising scandals put anyone with an Asian surname under a humiliating cloud of suspicion-with many perfectly legitimate donors receiving calls from the F.B.I.").

188. Cf. Derrick A. Bell, JR., RACE, RACISM AND AMERICAN LAW 177-78 (3d ed. 1992) (“[B]lacks, while citizens, are always subject to 'democratic domination'; their views, aspirations, even basic political rights subject to the prevailing belief that America, and every part of it, must be controlled by whites.”); Paul Butler, Racially Based Jury Nullification: Black Power in the Criminal Justice System, 105 YALE L.J. 677, 710 (1995) ("The implication of the failure to protect blacks from the tyrannical majority is that the majority rule of whites over African-Americans is, morally speaking, illegitimate.”); Lani Guinier, No Two Seats: The Elusive Quest For Political Equality, 77 VA. L. REV. 1413, 1479 (1991) (“[R]acism excludes minorities from ever becoming part of the governing coalition, meaning that the white majority will be permanent.... [S] uch a majority will 'marginalize' or ignore minority interests altogether.").

189. Cf. Jill E. Evans, Challenging the Racism in Environmental Racism: Redefining the Concept of Intent, 40 ARIZ. L. REV. 1219, 1230-31 (1998) (observing that "environmental decisionmaking is already stacked against the country's minorities, who as a group have fewer resources and less political representation with which to fund, research, and otherwise influence the environmental prioritization" (quoting Peter M. Manus, The Owl, the Indian, the Feminist, and the Brother: Environmentalism Encounters the Social Justice Movements, 23 B.C. ENVTL. AFF. L. REV. 249, 285-86 (1996))).

190. Cf. Martin H. Redish \& Kirk J. Kaludis, Redistributive Values and the Democratic Dilemma, 93 Nw. U. L. REV. 1083, 1096 (1999) ("If, under existing political structures, society will not even place the issue of substantive economic redistribution on the political agenda because those in political power are the very same individuals and entities who currently possess economic power, why are those very same power centers any more likely to place the issue of democratic redistribution on the political agenda?"). 
Education, ${ }^{191}$ legislative institutions often glean lessons from judicial pronouncements, and if courts were to acknowledge that money is not speech but in fact has property characteristics that dilute the political influence of historically disadvantaged Browns, public lawmaking may respond by supporting reform. Second, it is possible that a White majority would favor reform that mitigated political advantages enjoyed by the very wealthy, even if that reform also effectively mitigated the racial disparities between the White majority and the Brown minority. ${ }^{192}$ Third, the fact that powerful interests might decide to use the political process to block campaign finance reform should not provide cover for judges who use the judicial process to arrive at the same political result. ${ }^{193}$

Unexamined by the Reformers, the existing campaign finance system has profound consequences for race relations in America. Privately financed politics, framed by a history of facially discriminatory laws that have contributed to a present-day disparity in control over resources, reproduces racial disparities in the distribution of resources. Campaign finance doctrine plays a significant part in maintaining the racial allocation of economic and political resources. ${ }^{194}$

\section{Slippery Slopes}

One might accept the fact that current campaign finance jurisprudence lacks neutrality and affirmatively exacerbates racial disparities, yet still contend that heavy judicial scrutiny of legislative regulation is necessary because any other path would lead to state regulation of other constitutionally protected liberties. Rights to legal counsel, abortion, and contraception, as well as freedoms of religion and of the press, often depend, in part, on the use of financial resources. Recognizing that past discriminatory policies have shaped the existing distribution of resources, the logic advanced in this Article might allow for legislatures to mitigate racial disparities by limiting the amount individuals can spend in exercising these various liberties. ${ }^{195}$

191. 347 U.S. 483 (1954).

192. Cf. BELL, supra note 188, at 50 ("[P]rogress will occur for [African Americans] only if most whites perceive that their interests will benefit or not suffer any serious loss.").

193. Note that instead of refusing to adopt reforms, it is possible that powerful interests (including, but not limited to, racial groups) might enact enrichment-minded campaign finance legislation. Judicial adoption of a test that invalidates entrenching reform could deal with this problem. See Overton, supra note 163, at 1299-302 (2000) (describing a judicial test in which courts strictly scrutinize campaign finance reform found to cause entrenchment).

194. Cf. Kimberlé Williams Crenshaw, Color Blindness, History, and the Law, in THE HouSE That RACE Built: Black AmericAns, U.S. TERRAin 285 (Wahneema Lubiano ed., 1997) (observing that "[f]ormal equality in conditions of social inequality becomes a tool of domination, reinforcing that system and insulating it from attack").

195. Cf. Eugene Volokh, The Unintended Consequences of Three Proposals, 24 HARV. J.L. \& PUB. POL'Y 47, 59 (2000) ('Say that the fact that 'money is property, it is not speech' means the government has a fairly free hand in restricting your using money to speak. [This logic] would then 
Many individuals exercise constitutional liberties on a platform of background rules that are indeterminate and political, and if the background rules were constantly subject to question, all such liberties would be jeopardized. While the status quo's reliance upon the existing distribution of property may be imperfect, one might argue it at least provides a workable baseline for the allocation of privileges in society. ${ }^{196}$

This subpart does not purport to ultimately resolve the questions of whether and how to limit the consideration of past discrimination to the exercise of liberties in the campaign finance context. Drawing lines is admittedly very difficult, for as articulated below, there are good reasons to consider past discrimination in analyzing the exercise of other liberties. Instead, this subpart attempts to parse out distinctions that explain why the racial distribution of property is uniquely disturbing in the campaign finance context. Those who are reluctant to consider race outside of the campaign finance context will hopefully find comfort in the realization that the drawing of doctrinal boundaries is both theoretically and practically feasible.

A potential critique of considering race in the campaign finance context notes that past state-sponsored discrimination that has shaped the distribution of property also interferes with the ability of people of color to exercise liberties related to counsel, privacy, and religion. Just as past discrimination shapes disparities in campaign contributions and expenditures, it may also contribute to racial disparities in criminal convictions, out-of-wedlock pregnancies, and other social circumstances. Therefore, one would argue, courts might extend the consideration of race to allow legislatures to diminish racial disparities by restricting the amounts that individuals can spend on liberties related to counsel, privacy, and religion.

Legislative restrictions, however, would not help people of color to more effectively exercise liberties such as the right to criminal counsel, privacy, or religious freedom. ${ }^{197}$ Unlike the expenditure of money on speech,

equally enable the government to restrict your using money to get abortions, buy contraceptives, send your kids to private schools, hire a lawyer, or build a church.”).

196. See Strauss, supra note 39, at 1386 (arguing that " $[\mathrm{t}]$ he market ordering is preferable not because it is theoretically good but because the market-which reflects the decisions of many people, acting for different purposes - is not subject to some of the ends that can result when a decision is made by a single, purposive actor like the government").

197. Reparation payments may help people of color to exercise these liberties more effectively. Unfortunately, in describing harms that result from past discrimination, many who call for reparation payments overlook the fact that people of color are less able to use resources to exercise constitutional liberties. See Spencer Overton, Racial Disparities, Campaign Finance, and the Political Function of Property, 49 UCLA L. REV. (forthcoming 2002) (asserting that those who advocate for reparations should more specifically articulate political harms that arise from past discrimination, including interference with the ability to exercise rights to speech, counsel, press, and petition); $c f$. Shelley v. Kraemer, 334 U.S. 1, 10 ("Equality in the enjoyment of property rights was regarded by the framers of [the Fourteenth] Amendment as an essential pre-condition to the 
the expenditure of money by white individuals to exercise liberties related to counsel, privacy, and religion does not generally interfere with the ability of people of color to effectively exercise these same liberties. ${ }^{198}$ Granted, a greater percentage of whites than people of color may be able to afford to exercise these liberties, and limits on the amount that individuals could spend on such liberties might narrow racial disparities. Such limits, however, would not enhance the ability of people of color to effectively exercise these liberties. Unlike speech, the rights to criminal counsel, privacy, and religious freedom do not involve a "distinctive role in the political process"199 so that those who spend money obtain advantages in securing political decisions that bind those who cannot afford to spend money.

Distinctions between money spent on campaign speech and other types of speech are not as apparent. A Formalist might argue that adopting this Article's framework will lead to judicial deference to statutes that restrict the amount that an individual can spend to publish a book of poetry, make a movie about the Holocaust, or produce any other type of speech. Indeed, race theorists might assert that courts should not limit the analysis articulated in this Article to money used on campaign speech, as other types of expensive speech shape citizens' understanding of racial reality in the United States. Past discrimination has created racial disparities in wealth so that whites disproportionately own and control book publishing companies, recording companies, movie studios, and other major entities that produce expression. Through the media's barrage of stereotypical images related to language, conduct, and values, these entities enjoy significant influence not simply over government policy, but also over the meaning of racial identity (as understood by people of color as well as by whites). ${ }^{200}$ People of color

realization of other basic civil rights and liberties which the Amendment was intended to guarantee.").

198. Note some individuals' relative willingness to spend more may sometimes inflate the cost of the best attorneys, doctors, and contraceptives, putting such resources out of the financial reach of many people of color. Outside of the nature of economic markets, however, criminal defense counsel, privacy, and religion differ from property, speech, and political money, as the latter group may be used in ways that interfere with the ability of others to effectively exercise the same liberties. See Overton, supra note 163, at 1265 ("Like both property and speech, political money can be used to interfere with the interests of others.").

199. RAWLS, The Basic Liberties and Their Priority, in POLITICAL LIBERALISM 329-30 (1993) (asserting that his fairness principles do not extend to religious liberties because they do not constitute a "distinctive role in the political process").

200. Some race theorists have rejected the near absolute judicial protection of hate speech and other racially demeaning messages, arguing that the power of racist cultural messages should be curtailed in light of context, history, and politics. See generally MARI J. MATSUDA ET AL., WORDS THAT Wound: CRITICAL RACE TheORY, Assaultive SPEECH, AND THE FiRST AMENDMENT (1993); Richard Delgado, Toward a Legal Realist View of the First Amendment, 113 HARV. L. REV. 778, 779 (2000) (book review) ("Under the influence of radical feminism and critical race theory, this last remnant of 1890 s mechanical jurisprudence is beginning to give way to a view of speech that is flexible, policy-sensitive, and mindful of communication theory, politics, and setting."); Richard Delgado, First Amendment Formalism Is Giving Way to First Amendment Legal Realism, 
are unable to counter these images effectively in the marketplace of ideas because they do not control sufficient resources either to dictate alternative programming through media ownership or to form a high-end target audience for advertisers. ${ }^{201}$ Society should not force people of color to bear the costs of free speech disproportionately. ${ }^{202}$

While these harms are real and should not be overlooked, money spent on election-oriented speech - that which refers to or features a likeness of a clearly identified candidate or a ballot initiative-is used in a unique context. $^{203}$ The government has created the electoral process, and unlike the money spent on other types of speech, money spent on election-related speech is directly targeted to influence outcomes in this governmentally created institution. $^{204}$ The government should be able to determine the legitimacy of the tools used to influence outcomes in the governmentally created electoral process, and should be able to reject or restrict the use of the tools, such as private wealth, that individuals acquire in part due to obsolete and discarded discriminatory government policies. Further, movies and books may abstractly impact the lives of people of color, but the integrity of the electoral process is arguably more important because it produces quantifiable laws that legally bind all citizens. Finally, as stated above in subpart IV(B), the electoral process directly shapes the existing allocation of

29 HARV. C.R.-C.L. L. Rev. 169 (1994); Charles R. Lawrence III, If He Hollers Let Him Go: Regulating Racist Speech on Campus, 1990 DUKE L.J. 431. The problem arises, however, not simply from the images themselves, but also from the inability of people of color to counter derogatory images with more constructive images, which arises in large part from disparities of property gained through a history of state-sponsored racial discrimination.

201. Cf. Kurt A. Wimmer, The Future of Minority Advocacy Before the FCC: Using Marketplace Rhetoric To Urge Policy Change, 41 FED. COMM. L.J. 133, 141-42 (1989) (“All viewers are not valued equally by advertisers. [A] large audience may be desirable, prompting programmers to tailor programming to ... majority interests.... [A] small, high-income demographic may be desirable, prompting programmers to tailor programming to the young, white audience ... . Under either scenario, minority audiences are disenfranchised.").

202. Cf. Frederick Schauer, Uncoupling Free Speech, 92 ColUM. L. REV. 1321, 1357 (1992) (arguing that "the immediate fact that the cost of a constitutional right is being borne disproportionately by victims of its exercise ought at least to occasion more thought, especially in the First Amendment area, than it has to date").

203. Foley, supra note 36, at 1249-50 ("Equal-dollars-per-voter applies only to electoral activities, which I have defined to consist of activities in support of, or opposition to, a candidate or ballot initiative."); C. Edwin Baker, Campaign Expenditures and Free Speech, 33 HARV. C.R.-C.L. L. REV. 1, 50 (1998) ("This category of expenditures would include all specifically campaignoriented advertising within the media. It would also include groups' special attempts to spread an electoral message beyond their membership or usual audience, for example, broader than usual distribution of the organization's own media. This category, however, should cover only overtly election-oriented speech.”).

204. See Baker, supra note 203, at 48 ("By creating elections, the state creates not only the opportunity to run but also the opportunity to influence the legal output of elections ... [and] the institutionalization of elections can justify regulating behavior specifically directed at influencing these outcomes - for example, speech that is purposefully part of, not a reaction to or critique of, the process the state has created."). 
resources, and thus the spending of political money can result in laws that perpetuate racial disparities in wealth. ${ }^{205}$

Even if one accepts the distinctions between money spent on electionrelated speech and money spent to produce speech generally, the rationale advanced in this Article might be said to justify limits on the amounts of money spent by the press on election-related speech, such as endorsements, editorials, and news reports that discuss candidates or ballot initiatives. ${ }^{206}$ Alternatively, the rationale put forth in this Article might allow the government to mandate that the press provide a right of access to those who cannot otherwise afford to reach a broad audience. ${ }^{207}$ Distinguishing between the press and other entities in restricting spending on electionrelated speech is difficult, as news outlets are disproportionately owned and controlled by individuals who have not been disadvantaged by past racial discrimination. There are serious questions as to why this select group of individuals, simply because they own a particular type of property, should have a greater opportunity to influence the governmentally created electoral process, and shape the laws that bind all Americans and allocate resources. ${ }^{208}$ Despite claims to the contrary, many media outlets are not objective or impartial, but seek to maximize either their political influence or their profits by expanding their market share, which often comes at the expense of the interests of many people of color. ${ }^{209}$ One might argue, therefore, that courts

205. Cf. Overton, supra note 163, at 1291-92 n.222 ("Allowing for more regulation of political money does not necessitate a doctrinal change that allows for the regulation of... other property/speech intersections.... Political money is different for a number of reasons, including but not limited to the entrenching impact of the existing uneven distribution of property on future allocations of property (through lawmaking).").

206. Cf. Volokh, supra note 195, at 58 (arguing that "under [the money as property] approach, the government would acquire broad power to control newspapers . . . and anyone else who hires others to participate in creating a speech product"); Sanford Levinson, Regulating Campaign Activity: The New Road to Contradiction?, 83 MiCH. L. REV. 939, 946-48 (1985) ("To the extent that it strikes us as dubious - or indeed 'unthinkable' - to limit the ability of a newspaper to campaign actively for its favorite candidates, then we should at least question why it would be any more legitimate to limit the amount of spending by an individual eager to support the same candidate.").

207. Compare Miami Herald Publ'g Co. v. Tornillo, 418 U.S. 241 (1974) (finding a Florida statute that granted a political candidate the "right to reply" to press criticism with equal space in a newspaper violated the First Amendment), with Red Lion Broad. v. FCC, 395 U.S. 367, 395-96 (1969) (finding that the federal "fairness doctrine" did not violate the First Amendment by requiring "a radio or television station to give reply time to answer personal attacks and political editorials").

208. Cf. Foley, supra note 36, at 1252 ("The owners of newspapers should have no greater opportunity, simply by virtue of owning this property, than any other citizen to attempt to persuade undecided voters how to vote on election day."); Richard L. Hasen, Campaign Finance Laws and the Rupert Murdoch Problem, 77 TEXAS L. REV. 1627, 1665 (1999) ("But if we one day come so far as to be able to regulate political equality generally through our campaign finance laws, it seems anomalous to exempt Rupert Murdoch, defense contractors, Mickey Mouse and a host of other characters simply because they used their wealth to buy a newspaper or broadcast station.").

209. Cf. Ben H. Bagdikian, The Media Monopoly 5 (5th ed. 1997) (asserting that individuals purchase news outlets for either monetary profit or political influence); Hasen, supra 
would extend the concepts in this Article to empower legislatures to place restrictions on the amount the media spends on election-related speech.

Despite the fact that past discrimination may adversely impact minorities in their ability to own and control news outlets, there also seem to be reasons to distinguish the use of political money from expenditures by the press. The media plays an important role in democracy that differs from the role played by those who finance political advertisements. A media company does not simply spend resources on expression during election time to further its own political interests, but it is in the regular business of imparting news and opinion to the public. ${ }^{210}$ A media outlet is not merely a platform for its owner, but also often provides a forum for the perspectives of various individuals, including people of color. Media outlets also expose and check government abuses. ${ }^{211}$ While those who give or spend large sums of political money could theoretically perform the same function, in practice they often facilitate abuses and entrench their own interests, which generally do not further and are often counter to the interests of those who have suffered from past discrimination. In addition, one might argue that the text of the Constitution distinctly and more expansively protects press freedoms. ${ }^{212}$

Admittedly, the theoretical distinctions between the campaign finance context and the exercise of other liberties may appear result-oriented, as a single, overarching, and neutral principle does not bind them all together. In practice, one might argue, the distinctions are subjective, value-laden, and temporary. Once courts consider past discrimination and allow for more ex-

note 208 , at 1630-31 (examining "the evidence indicating that media owners are profit or influence maximizers").

210. Cf. Austin v. Mich. Chamber of Commerce, 494 U.S. 652, 667 (1990) (observing that "media corporations differ significantly from other corporations in that their resources are devoted to the collection of information and its dissemination to the public"); Baker, supra note 203, at 49 ("The press (newspapers and other on-going media, in contrast to special partisan media created just for the period of the campaign and designed just to influence the campaign) must be allowed to engage in unrestricted campaign coverage and comment, including endorsements. . . Any attempt to restrict these activities would go beyond campaign regulation and intrude into politics in the wider sense."); Thomas W. Joo, The Modern Corporation and Campaign Finance: Incorporating Corporate Governance Analysis into First Amendment Jurisprudence, 79 WASH. U. L.Q. 1, 6 n.16 (2001) (distinguishing regulation of corporate election-related spending from state censorship of editorializing by media enterprises, and arguing that "[e]ditorializing is the very business of the media" and that shareholders in such corporations "can be more accurately described as having authorized the use of corporate resources for political speech").

211. See Mills v. Alabama, 384 U.S. 214, 219 (1966) (“[T] he press serves and was designed to serve as a powerful antidote to any abuses of power by governmental officials and as a constitutionally chosen means for keeping officials elected by the people responsible to all the people whom they were selected to serve.").

212. Cf. Hasen, supra note 39, at 1657 ("In addition, the media could argue that the Constitution separately, and more generously, protects freedom of the press compared to freedom of speech.”); Potter Stewart, “Or of the Press,” 26 HASTINGS L.J. 631, 633 (1975) (“The publishing business is, in short, the only organized private business that is given explicit constitutional protection."). 
tensive regulation in the campaign finance sphere, government will attempt to restrict other liberties, and courts will cede to these demands.

These dangers, however, are remote. Existing campaign finance statutes already limit contributions that individuals may make to candidates and prohibit corporations and unions from making contributions to candidates or spending money in connection with candidate elections. ${ }^{213}$ These laws have not inspired legislatures to limit the amount the press spends on election-related speech or the amount an individual spends to exercise other liberties, such as religious freedoms. ${ }^{214}$ Further, legislatures can enact reasonable regulations for obscenity and other types of speech only because courts have engaged in subjective, value-laden line drawing, ${ }^{215}$ and such distinctions have not led to a judicial disregard for expressive liberties generally. ${ }^{216}$ In short, rhetorical fears about slippery slopes should not impede one's willingness to consider race in the campaign finance context.

\section{The Consideration of Race in Looking Toward Solutions}

This Article has explored assumptions about the political realities of democracy embedded in the Reformers' critique of current constitutional jurisprudence and how these perspectives overlook important historical and contemporary factors related to race and the distribution of property. But even if courts were to give greater deference to the political branches with regard to campaign finance, detailed and effective legislative solutions would come only through broader discussions that incorporate a more comprehensive analysis of race into the campaign finance debate. To spark conversations that will eventually lead to more appropriate remedies, this Part builds on the previous sections by sketching out some initial strategies in approaching race and campaign finance reform and addresses some of the concerns with such strategies. First, however, this Part explains why the

213. See 18 U.S.C. $§ 608(b)(1)$ (Supp. IV 1974) (modified 1976, recodified at 2 U.S.C. $\S 441 \mathrm{a}(\mathrm{a})(1)(\mathrm{A})$ ) (prohibiting an individual from giving more than $\$ 1000$ to a particular candidate per election); 2 U.S.C. $\$ 441 b(a)$ ("It is unlawful for any . . corporation ... or labor organization to make a contribution or expenditure in connection with any election ....").

214. Cf. Hasen, supra note 208, at 1658 ("Many laws already in existence govern if and how non-media entities may contribute to or make independent expenditures in connection with federal candidates. These laws have not led to widespread censorship in other areas of political life ....”).

215. Cf. Richard H. Pildes \& Frederick Schauer, Electoral Exceptionalism and the First Amendment, 77 TEXAS L. REV. 1803, 1826 (1999) ("With these slogans and metaphors, the tradition encourages avoiding even independently justifiable regulations of communications for fear of being unable to draw the line between the justifiable and the unjustifiable, and for fear of a causal relationship between justifiable regulation now and unjustifiable regulation later.").

216. $C f$. id. at 1828 ("In permitting the regulation of commercial advertising under standards that are more easily satisfied than the standards for the regulation of "core" First Amendment speech, the Supreme Court has relied on a boundary between commercial advertising and other speech that is no more clear and impermeable than a putative boundary between electoral speech and other forms of political speech."). 
most relevant existing legal directive, the Voting Rights Act, does not adequately resolve the problems surrounding race and campaign finance.

\section{A. The Voting Rights Act}

Although racial exclusion in the political sphere motivated its passage, the Voting Rights Act of 1965 does not comprehensively remedy such exclusion in the campaign finance context. The Voting Rights Act prohibits not only restrictions intentionally designed to deny minorities the formal right to vote ${ }^{217}$ but also electoral practices that have the effect ${ }^{218}$ of denying protected classes the right to cast a meaningful vote. ${ }^{219}$ The statute was enacted to enforce the Fifteenth Amendment, ${ }^{220}$ which "opens the process to persons who had previously been excluded" and thus "seeks to enforce the representative's duty of equal concern and respect."221

Section 2 of the Voting Rights Act prohibits the enactment of an electoral arrangement that results in the dilution of minority voting

217. "There is more to the right to vote than the right to mark a piece of paper and drop it in a box or the right to pull a lever in a voting booth." S. REP. NO. 97-417, at 19 (1982) (Senate Report to 1982 Voting Rights Act amendments) (quoting Reynolds v. Sims, 377 U.S. 533, 555 n.29 (1964)), reprinted in 1982 U.S.C.C.A.N. 177, 196; see also Terry v. Adams, 345 U.S. 461, 469 (1953) (finding a violation of the Fifteenth Amendment despite access of African Americans to the formal right to vote).

218. The Act does not require a showing of intentional discrimination. See Voting Rights Act Amendments of 1982, Pub. L. No. 97-205, § 3, 96 Stat. 134 (codified as amended at 42 U.S.C. $\S 1973$ (1988)) (amending Voting Rights Act to supplement Mobile v. Bolden, 446 U.S. 55, 62 (1980), which held that "action by a State that is racially neutral on its face violates the Fifteenth Amendment only if motivated by a discriminatory purpose"); Dougherty County Bd. of Educ. v. White, 439 U.S. 32 (1978) (holding that a change in regulations that was not facially discriminatory but that affected the ability of candidates to run for office was subject to $\S 5$ preclearance requirement).

219. See 42 U.S.C. $§ 1973$ (b) (1994) (establishing the right of protected classes to enjoy the same opportunity to participate and to elect representatives of their choice as others); id. $\S 1973$ (c)(1) (noting that the term "voting" includes "all action necessary to make a vote effective"); Kathryn Abrams, "Raising Politics Up": Minority Political Participation and Section 2 of the Voting Rights Act, 63 N.Y.U. L. REV. 449, 454 (1988) (noting that diminution in the effectiveness of minority participation resulting in a $\S 2$ violation can "be a result of electoral processes, such as polling or registration procedures, making elected positions appointive, or of districting arrangements"); Binny Miller, Who Shall Rule and Govern? Local Legislative Delegations, Racial Politics, and the Voting Rights Act, 102 YALE L.J. 105, 146 n.246 (1992) (noting that "section 2 protects political participation beyond the formal right to vote" and therefore may invalidate electoral practices such as multimember districts).

220. See U.S. CONST. amend. XV, $§ 1$ (declaring that the "right of citizens of the United States to vote shall not be denied or abridged by the United States or by any State on account of race, color, or previous condition of servitude"); South Carolina v. Katzenbach, 383 U.S. 301, 337 (1966) (upholding the Voting Rights Act as a means of enforcing the Fifteenth Amendment); Gomillion v. Lightfoot, 364 U.S. 339, 341 (1960) (holding that municipal boundaries that excluded African Americans could be challenged under the Fifteenth Amendment).

221. See ELY, supra note 177, at 98 ("The Fifteenth Amendment, forbidding abridgment of the right to vote on account of race, opens the process to persons who had previously been excluded and thus by another strategy seeks to enforce the representative's duty of equal concern and respect.”). 
strength. $^{222}$ A claimant establishes a violation of section 2 by showing, on the totality of the circumstances, ${ }^{223}$ that "the political processes leading to the nomination or election in the State or political subdivision are not equally open to participation" by a racial minority group "in that its members have less opportunity than other members of the electorate to participate in the political process and to elect representatives of their choice."224

While the electoral arrangements challenged under section 2 have generally been redistricting plans, a campaign finance system based on the existing distribution of wealth could arguably constitute a "political process" that is not "equally open to participation" by minorities. Because they control fewer resources, people of color generally have less opportunity than others to participate in politics and elect representatives of their choice. A political process based on private money gives wealthier white communities disproportionately large influence in determining all candidates, and, like the lines drawn for some electoral districts, it effectively excludes poorer minorities from meaningful participation in the selection of their representatives. ${ }^{225}$ Indeed, courts have cited racial disparities in the campaign finance context in support of their findings that certain legislative districts violated section $2 .^{226}$

222. 42 U.S.C. $\$ 1973(b)$ (1994).

223. See Thornburg v. Gingles, 478 U.S. 30, 79 (1986) ("[T]he trial court is to consider the 'totality of the circumstances' and to determine, based 'upon a searching practical evaluation of the "past and present reality," whether the political process is equally open to minority voters.").

224. 42 U.S.C. $\$ 1973($ b) (1994).

225. In their lone mention of the impact of the campaign finance system on racial minorities, Raskin and Bonifaz acknowledge in a footnote that the financial disadvantages faced by minority candidates in statewide races or in majority white districts are inconsistent with $\S 2$, but they then assert that this financial disadvantage is mitigated in majority African American and Latino districts. See Raskin \& Bonifaz, Equal Protection, supra note 37, at 279 n.26. The scholars admit that their research is "[p]reliminary" and that "[t]he question of a Voting Rights Act violation ... is beyond the scope of this Article." See id. As articulated in section III(B)(3), political money from predominantly white communities can significantly impair the electoral choice of people of color in both "majority minority" and predominantly white electoral districts.

226. In determining whether a districting plan (rather than a plan for financing campaigns) violates $\S 2$ of the Voting Rights Act, courts consider a variety of factors, including but not limited to the effects of discrimination which hinder the ability of protected classes to participate effectively in the political process. See S. REP. NO. 94-417, at 28-29 (1982) (describing the fifth Senate Factor as "the extent to which members of the minority group in the state or political subdivision bear the effects of discrimination in such areas as education, employment and health, which hinder their ability to participate effectively in the political process"), reprinted in 1982 U.S.C.C.A.N. 177, 206. In determining that reapportionment plans dilute minority voting rights in violation of $\S 2$, a number of courts have cited economic disparities hindering minority political participation in the campaign finance context. See, e.g., Rural W. Tenn. African Am. Affairs Council, Inc. v. Sundquist, 29 F. Supp. 2d 448, 459 (W.D. Tenn. 1998) ("The economic and educational isolation of AfricanAmericans ... limits their ability to fund and mount political campaigns. In this sense therefore, blacks are not able to equally participate in the political process."); Cofield v. City of LaGrange, 969 F. Supp. 749, 768 (N.D. Ga. 1997) ("The economic disparity between the races in LaGrange translates into a disparity in the ability to impact the local political process. For example, in the 1995 elections for City Council, none of the African-American candidates received more total monetary contributions than any of the white candidates. The African-American candidates 
Section 5 of the Voting Rights Act may restrict some changes to a state or local system for financing politics, such as increased contribution limits. Under section 5 of the Act, a covered state may not implement a change in its election laws unless it demonstrates that the change will be free of racially discriminatory effects. ${ }^{27}$ Increased contribution limits have a retrogressive impact on minorities' effective exercise of the franchise because increased limits enhance the electoral advantage of candidates favored by whites and add to the comparative disadvantages faced by minority voters' preferred candidates. $^{228}$ If a jurisdiction covered by section 5 were to propose increases to contribution limits, compliance with section 5 might require that the jurisdiction obtain preclearance from federal officials because the increased limits constitute "changes to election laws." 229

While many current state and local systems for funding politics might be said to violate sections 2 and 5 of the Voting Rights Act, an application of the Voting Rights Act does not comprehensively resolve the racial harms that private money causes. The Voting Rights Act could be used, at most, to challenge state political money laws, as it is unlikely that the Act would be construed to invalidate federal financing provisions. Further, looking to the federal limits as a model, it is unlikely that a court would find a violation when state contribution limits either match or are below the federal limits. Also, only particular geographic areas are required to submit their changes in

received an average of $\$ 825.12$ in contributions, and the white candidates received an average of \$2,825.90 per candidate.”); McDaniels v. Mehfoud, 702 F. Supp. 588, 595 (E.D. Va. 1988) (“The median income for black families in the county is $\$ 19,824$ versus $\$ 23,202$ for white families. In Henrico County, $11.2 \%$ of the black population and $5.2 \%$ of the white population lives below the poverty line.... The Court finds that these differences adversely affect the ability of black citizens to participate in and influence the political process in Henrico County. For example, while black candidate Thornton received slightly over $\$ 20,000$ in contributions to his 1987 supervisory campaign, his white opponent, Waldrop, received slightly over $\$ 40,000$.”).

227. See Georgia v. United States, 411 U.S. 526, 538 (1973) (observing that $\S 5$ of the Voting Rights Act "essentially freezes the election laws of the covered States unless a declaratory judgment is obtained in the District Court for the District of Columbia holding that a proposed change is without discriminatory purpose or effect").

228. The National Voting Rights Institute, founded by John Bonifaz, submitted a letter to the Justice Department making this argument in response to increased contribution limits in Georgia. See Letter from Brenda Wright, Managing Attorney, National Voting Rights Institute, to Joseph Rich, Chief of the Voting Section, Civil Rights Division, Department of Justice (Aug. 4, 2000) (on file with the Texas Law Review) ("Georgia's effort to double the amounts that contributors may give ... is clearly retrogressive with respect to minorities' effective exercise of the franchise ...."). The Justice Department initiated its investigation by sending correspondence to Georgia inquiring as to what types of studies had been undertaken to determine the impact of the increased contribution limits on communities of color.

229. See 42 U.S.C. $\$ 1973$ c (1994) (requiring that particular states submit proposed changes to election laws to the Justice Department or a special three-judge panel of the U.S. District Court for the District of Columbia for preclearance in anticipation of revisions that effectively dilute the voting strength of racial minorities). 
election practices for preclearance under section $5,{ }^{230}$ and thus most areas would be able to raise their contribution limits and dilute the influence of people of color without concern for judicial or Justice Department approval. Finally, due to Buckley's invalidation of spending limitations, the Voting Rights Act does little to address problems arising from the lack of spending limits. The wealthy, who are overwhelmingly white, could continue to spend as much as they wanted on their own campaigns or the campaigns of others.

Despite the failure of the Voting Rights Act to resolve all problems regarding race and campaign finance, the Voting Rights Act and judicial interpretations of the statute are important in principle. The doctrine establishes that courts and legislatures have concerned themselves with identifying and eliminating electoral practices that not only intentionally ${ }^{231}$ but also effectively minimize the opportunity of people of color to participate in the political process.

\section{B. Racial Consideration}

A separate, more general approach to campaign finance would encourage decisionmakers to consider whether a facially race-neutral legal pronouncement tends to reaffirm or exacerbate the effects of past laws and practices that discriminated against people of color. ${ }^{232}$ Courts and legislatures regularly employ policy considerations as analytical tools in determining how to create and apply law. Such policy considerations include fairness arguments related to individual and group rights, justice in social relationships, social utility, economic efficiency, and concern for the general welfare. ${ }^{233}$ Contextual approaches such as law and economics have offered

230. See id. (exploring preclearance requirements and applying them to the political subdivisions described in $\S 1973 \mathrm{~b}(\mathrm{~b}))$.

231. See Voting Rights Act Amendments of 1982, Pub. L. No. 97-205, § 3, 96 Stat. 134, (codified as amended at 42 U.S.C. $§ 1973$ (1988)); Dougherty County Bd. of Educ. v. White, 439 U.S. 32, 43 (1978).

232. Professor Martha Minow suggests that one strategy to address the wounds that propel identity politics includes a commitment to reversing the effects of categorical exclusions without deploying group-based categories in governmental decisionmaking. See Minow, supra note 8, at 675 (proposing to "address the systemic harms that animate and perpetuate identity politics" in part through "sustained public acknowledgment of past and continuing oppressions on group-bases and support for individual self-fulfillment without the truncated effects of assigned group identities"). Professor Minow cites one example as "[a]rchitectural designs for buildings that accommodate people who use wheelchairs without segregating them in separate entrances and elevators ...." Id. at 687 .

233. See SINGER, supra note 10, at 279-82 (describing the use of policy as an analical tool in lawmaking). The consideration of race is related to existing policy considerations and cuts across both fairness and social-utility considerations. Most obviously, it requires a consideration of justice to communities of color and a respect for the rights of individuals within these communities. A consideration of race also inquires into the social consequences of a particular decision and ensures that all Americans are included in our concern for the general welfare. The consideration of race is not unique in its relation to existing values considered by courts, since other policy considerations, such as social utility and general welfare, overlap with one another. Despite the overlap, the 
penetrating insights into the workings of campaign finance, ${ }^{234}$ and a racial analysis is no less promising.

In considering race, one need not employ a constitutional pronouncement that mechanically locks decisionmakers into reaching one conclusion and excludes the consideration of other factors. ${ }^{235}$ Considering race does not restrict legislators to enacting only those campaign finance laws most beneficial to people of color, and it does not prevent judges from finding against litigants who are people of color. Racial consideration is not the rhetorically infamous "race card" that trumps all other considerations. ${ }^{236}$ Instead, race is one policy consideration that should sometimes be employed by legal decisionmakers in conjunction with other factors. ${ }^{237}$

One might assert that an independent consideration of race is irrelevant in designing legislative reforms, as any reform that assists the poor will benefit people of color. The thought is that while the injustice of racial

historical and contemporary importance of race in shaping the distribution of wealth, as well as the racial composition of the population, warrants that we formally consider race on its own grounds. Deconstructing and hiding race behind several other policy considerations obscures its significance. The whole of racial consideration is more than the sum of its parts. Familiarity with other overlapping policy arguments should only breed confidence in the value of the consideration of race as a credible analytical tool.

234. See Elizabeth Garrett, Law and Economics, 31 N.M. L. REV. 107, 117 (2001) (suggesting "three ways in which law and economics can help campaign finance reform efforts and our analysis of those efforts"); Hasen, supra note 39, at 7 (proposing a campaign finance plan that "reforms the political market with proper incentives and safeguards that channel self-regarding political behavior to produce fair and efficient political outcomes," but replaces "normative public choice theory's efficiency criterion with the normative goal of promoting an egalitarian pluralist political market"); Justin A. Nelson, Note, The Supply and Demand of Campaign Finance Reform, 100 COLUM. L. REV. 524 (2000) (arguing that most campaign finance regulations fail because they overemphasize restricting the supply of private money, and that future reforms should focus on decreasing politicians" demand for private money). "Law and economics" is contextual in that law is examined in the context of economic markets, incentives, and efficiencies, and a consideration of race is contextual in that law is examined in the context of racial history and current racial relations. $C f$. Blake D. Morant, The Teachings of Dr. Martin Luther King, Jr. and Contract Theory: An Intriguing Comparison, 50 ALA. L. REV. 63, 102-03 (1998) ("Pursuant to [contextualism], law is examined in light of the problems, policies, or ideological assumptions which accompany its genesis and application.... [S]eemingly objective rules cannot be applied blindly without regard for the contextual realities that shape an event and influence the actors and the decision makers.").

235. A consideration of race in making decisions does not revise judicial tests developed to establish a violation of the Equal Protection Clause of the Fourteenth Amendment. It is not an attempt to replace the Equal Protection Clause's discriminatory-intent requirement with a discriminatory-impact requirement. See Washington v. Davis, 426 U.S. 229, 239-40 (1976) (holding that in order to establish a claim that a facially neutral law violates equal protection, plaintiffs must prove a racially discriminatory intent or purpose on the part of those responsible for the law's enactment or administration).

236. A racial analysis is just like any other policy consideration in that it lacks utility and is "unpersuasive in its extreme form." See SINGER, supra note 10, at 279 (observing that "[e]ach of the [policy] arguments is unpersuasive in its extreme form").

237. The consideration of race, not unlike policy analysis generally, is not a science and would be applied in ways that are beyond precise measurement. The application of policy analysis is context-specific. Different individual decisionmakers use different policy considerations when confronted by different facts. 
discrimination may provide an additional reason for courts to tolerate or legislatures to enact campaign finance reform, people of color are disadvantaged due to their economic status, not their racial status. Any reform that benefits the poor will thus equally benefit minorities, the argument goes, and a separate racial analysis of a reform adds nothing.

Civil-rights groups, elected officials, activists, and academic commentators have recently used race in analyzing proposed reforms, however, and their examinations have exposed concerns that class-based reformers have overlooked. For example, the law permits corporations, unions, and individuals to give unlimited soft money contributions to political parties, but restricts the parties' use of soft money to "party building" projects, like voter mobilization. ${ }^{238}$ The recently enacted Bipartisan Campaign Reform Act prohibits soft money gifts after November 6, 2002. ${ }^{239}$ Conventional Reformers assume that the ban on soft money will help less wealthy economic classes, including but not limited to racial minorities, who are generally deprived of the special access enjoyed by those who give soft money. ${ }^{240}$ The analysis of conventional Reformers, however, is incomplete, because it does not consider the extent to which political parties use soft money to support both voter mobilization in communities of color and minority candidates. A person considering race might assert that banning soft money contributions will harm communities of color because doing so will eliminate over $\$ 40$ million that political parties use to encourage voter turnout ${ }^{241}$ including voter turnout by Democrats in predominantly African

238. See CORRADO, supra note 20, at 68 . The Federal Election Commission initially allowed parties to raise soft money in unlimited amounts and use the funds for party-building activities such as voter registration and voter mobilization, but these uses expanded in the 1980s to include party overhead, infrastructure improvements, and other indirect support for candidates, and more recently to include electioneering communications that directly support or attack clearly identified federal candidates. Richard Briffault, The Political Parties and Campaign Finance Reform, 100 COLUM. L. REV. 620, 629-31 (2000). (2002)

239. Bipartisan Campaign Reform Act of 2002, Pub. L. No. 107-155, § 101, 116 Stat. 81

240. See, e.g., Letter from Scott Harshbarger, President \& CEO of Common Cause, to all members of the Congressional Black Caucus (July 11, 2001), available at http://commoncause.org ("[T]he current soft money system is a loser for the constituency you represent. I say this without making great assumptions about your constituents, but simply by knowing that the current soft money system is bad for almost every American, save those few who have the financial resources to become major players in the pay-to-play system.").

241. In discussions of campaign finance reform, some members of the Congressional Black Caucus articulated concerns that a ban on soft money will impair voter mobilization in African American communities. See Juliet Eilperin, House Tackles Campaign Reform; Representatives Remain Divided on McCain-Feingold Bill, WASH. PosT, May 2, 2001, at A6, 2001 WL 17625060 (mentioning that "a number of Democrats ... including members of the Congressional Black Caucus, have expressed concern that the Senate bill would undermine the parties' ability to mobilize voters"); Alison Mitchell \& Adam Clymer, Democrats Maneuver on Soft Money as Vote Nears, N.Y. TIMES, July 11, 2001, at A12, LEXIS, Nexis Library, NYT File (reporting that Congressional Black Caucus member Albert Wynn is convinced "that soft money [is] needed for spending on voter education and getting out the minority vote"); Conti, supra note 6, at 132 
American communities. ${ }^{242}$ Further, the argument goes, national parties use soft money to pay for issue advertisements that support viable minority candidates who have difficulty raising money, and the ban on soft money might jeopardize the political prospects of these candidates. ${ }^{243}$

Similarly, by focusing on class the Reformers also overlook important racial variables arising from reform proposals that would prohibit a candidate from accepting contributions from residents outside of her electoral district. $^{244}$ The thought behind such a proposal is that poorer residents of a particular electoral district should not be forced to compete for the attention of their representatives with more wealthy out-of-district contributors. A consideration of race, however, reveals that such restrictions might disadvantage some candidates of color running in districts comprised of predominantly white populations-like U.S. Senate candidates Carol Moseley Braun and Harvey Gantt - who rely on out-of-district contributions.

Even if one accepts that a consideration of race adds an analytical element that a consideration of class overlooks, one might be troubled by the fact that a consideration of race does not provide a definitive conclusion as to the merits of a particular reform. Those who consider race are far from unanimous in their opinions regarding particular reforms, as persuasive arguments can be made as to why many reforms that help the poor also help people of color.

For example, some who consider race support the soft money ban, and assert that any benefits that people of color gain from soft money are

(asserting that challenger candidates would have had to raise an additional $\$ 40$ million for voter turnout had soft money been banned in the 2000 election cycle). In response to these concerns, the Bipartisan Campaign Reform Act allows state and local parties to accept up to $\$ 10,000$ each year per individual for get-out-the-vote and voter-registration efforts in federal elections. See Bipartisan Campaign Reform Act of 2002, Pub. L. No. 107-155, § 101, 116 Stat. 81 (2002) (“[N]o person (including any person established, financed, maintained, or controlled by such person) may donate more than $\$ 10,000$ to a State, district, or local committee of a political party in a calendar year...."). In the interests of full disclosure, the author of this Article advised several members of the Congressional Black Caucus on the merits and shortcomings of various campaign financereform proposals.

242. Along similar lines, Professor Samuel Issacharoff has asserted that certain provisions of the Bipartisan Campaign Reform Act could be interpreted to restrict the ability of the NAACP National Voter Fund and churches to mobilize voters in minority neighborhoods. See Issacharoff, supra note 6, at 1530 ("The unexplored implications of [the Bipartisan Campaign Reform Act] could reach as far as the activities of non-partisan institutions ... that assist in voter mobilization campaigns in cooperation with political parties.... [The Act's] further reaches could include many of the functions that have become a hallmark of black political mobilization.").

243. See Conti, supra note 6, at 133 (asserting that "when viable minority and female candidates need money, the party steps forward to provide support" with soft money).

244. Cf. Raskin \& Bonifaz, Equal Protection, supra note 37, at 295 ("PACs located in Washington or New York occupy a far more significant role in the wealth primary than do poor or moderate-income voters in the official's home state or district. . . Similarly, large contributions by wealthy interests from out-of-state are certainly more important than contributions from poor and median-income voters who live in the state or district."). 
minimal and outweighed by political disadvantages. Most voter mobilization activities in communities of color are overwhelmingly financed not by soft money, but by party "hard money" 245 and through the efforts of labor unions and nonpartisan groups like the NAACP National Voter Fund ${ }^{246}$ the National Coalition on Black Voter Participation, and the A. Philip Randolph Institute. ${ }^{247}$ Further, the vast majority of soft money is spent not on voter mobilization activities, ${ }^{248}$ but on issue advertisements targeted at swing voters, who are almost always white. There is "scant evidence that soft money is used to promote minority issues" among these swing voters. ${ }^{249}$ Therefore, the argument goes, the negligible benefits of soft money are outweighed by political marginalization, because very few minorities benefit from the access that large soft money contributors enjoy. ${ }^{250}$

The split in opinion among those who employ the lens of race is not limited to soft money reforms. One might assert that reforms that would prohibit a candidate from accepting contributions from those who reside

245. Anthony Corrado provides a definition of "hard money": "Hard money is the money raised under federal contribution limits for use in federal elections. .. . Hard money can be used for any purpose and is the only funding that can be used to finance activities that directly benefit and advocate the election or defeat of federal candidates . ..." CORRADO, supra note 20, at 67-68.

246. Michael A. Fletcher, In Targeted States, A Striking Turnout Of Black Voters, WASH. PosT, Nov. 17, 2000, at A29 (attributing the high turnout of African American voters in the 2000 presidential election in part to the fact that "the NAACP National Voter Fund ... spent \$10 million to register and turn out black voters").

247. In advising the Congressional Black Caucus on this issue, The Fannie Lou Hamer Project has argued that the ban on soft money is beneficial to communities of color, in large part because the benefits of soft money to people of color are overstated. See Memorandum from The Fannie Lou Hamer Project, to the Congressional Black Caucus Members 4 (May 15, 2001) (on file with the Texas Law Review), available at http://home.att.net/ sodafam/fannielou/cbcmemo.htm.

248. See The Brennan Center for Justice at NYU School of Law, The Purposes and Beneficiaries of Party "Soft Money" (last modified July 3, 2001), available at http:// www.brennancenter.org/resources/downloads/purposes_beneficiaries070301.pdf (finding that just $8.3 \%$ of soft money spent by the Republican and Democratic parties went to voter education, phone banks, voter registration, get-out-the-vote drives, and other traditional party-building activities); Donna Brazile, Soft Money's Scanty Leftovers, N.Y. TIMES, July 11, 2001, at A17, LEXIS, Nexis Library, NYT File (arguing that soft money does not "really help the democratic process in minority communities," because most soft money "is spent on television ads or on media consultants" and only "scanty leftovers remain for increasing voter turnout and participation among minorities and in poor communities").

249. Smith, supra note 6, at 1515 ("Quite apart from the development and election of black candidates, there is likewise scant evidence that soft money is used to promote minority issues, thus creating a greater substantive basis for minority voter participation in the electoral process.").

250. John Conyers, The Truth About the CBC and a Soft Money Ban, Roll CALL, July 12, 2001, at 14 ("[I]n practice, soft money puts [African American] issues at the back of the bus.... Gun violence is the No. 1 cause of death for 15- to 34-year-old black males, but the soft money of the gun lobby blocks legislation to keep guns out of criminals' hands."); Memorandum from The Fannie Lou Hamer Project, to the Congressional Black Caucus Members 5 (May 15, 2001) (on file with the Texas Law Review) (asserting that "soft money contributors and fundraisers enjoy disproportionate authority in the Democratic Party" and that a "ban on soft money would allow for a more inclusive Democratic Party that would better represent the interests of people of color"), available at http://home.att.net/ sodafam/fannielou/cbcmemo.htm. 
outside of her electoral district disproportionately benefit people of color. Minority-elected officials who represent predominantly minority populations often receive a large percentage of out-of-district contributions. A ban on such contributions, the argument might go, enhances the accountability of minority representatives to their constituents. Individuals considering race may also arrive at different conclusions with regard to other reforms, such as increases or reductions in the amounts individuals ${ }^{251}$ or political action committees ${ }^{252}$ can contribute to candidates.

251. For example, the Bipartisan Campaign Reform Act (also known as "McCain-Feingold") doubles the amount of money an individual can contribute to a federal candidate from $\$ 1000$ to \$2000. Bipartisan Campaign Reform Act of 2002, Pub. L. No. 107-155, § 307, 116 Stat. 81 (2002). Some assert that people of color make fewer large contributions of hard money than do whites, and that under a regulatory scheme contemplated by the Bipartisan Campaign Reform Act, people of color would have even less influence over the political process. Additionally, minority candidates would be disadvantaged with increased contribution limits because they have more difficulty than white candidates in raising large contributions. See Smith, supra note 6, at 1513 (asserting that "McCain-Feingold exacerbates hard money funding inequities between black and white candidates"); Conti, supra note 6, at 138 ("While raising contribution limits is typically just one element in a package of reforms, it does not appear as though it would have any benefit to female or black candidates and would most likely prove problematic."); Spencer Overton, Reform for the Rest of America, WASH. POST, May 10, 2001, at A31, 2001 WL 17627323 (asserting that some members of the Congressional Black Caucus "raise legitimate concerns about" McCain-Feingold, and the bill "dismisses ... values of inclusion and participation by raising hard money contribution limits from $\$ 1,000$ to $\$ 2,000$ ”); see also Robert Moore, Short Changed: Race and Campaign Finance Reform (Aug. 24, 2000), at http://www.innercitynews.com/special_report_from_the_nnpa_inv.htm (finding that as of June 2000 , more than $\$ 1.2$ billion had been raised for the 2000 federal elections, less than $1 \%$ of which had been received by African American incumbents and challengers); JOEL A. THOMPSON \& GARY F. MONCRIEF, CAMPAIGN FINANCE IN STATE LEGISLATIVE EleCtiONS 154 (1997) (observing that "minority candidates, for the most part, raise and spend less than nonHispanic white candidates," and asserting that this factor may be particularly problematic in light of recent U.S. Supreme Court decisions that limit the use of race as a criteria for drawing electoral districts"). In response, those in favor of increased contribution limits have argued that most minority candidates run against other minority candidates, and are thus not disadvantaged by an increase in contribution limits that allows two white candidates, who are running in a neighboring district, to raise and spend twice as much. Lowenstein, supra note 6, at 1537-38 ("Two black candidates opposing each other in one district would not be disadvantaged because two white candidates in a neighboring district spent twice as much."); A Stall in the House, WASH. POST, May 10,2001 , at A30 ("A candidate from a low-income district will by definition face a rival from the same district. If the pool of available funds turns out in fact to be low, it will be low for both."). To the extent minority incumbents face fewer electoral challenges because they are able to raise even more than minority challengers under the increased limits, the argument goes, their minority constituents benefit, because seniority has importance in most legislatures. See Lowenstein, supra note 6 , at 1538 .

252. Recognizing that minority candidates receive a larger percentage of their contributions from PACs, one could argue that a ban or lowered limit on PAC contributions might adversely impact people of color. See Sunstein, supra note 32, at 1409-10 ("Sometimes minority candidates can succeed only with the help of PACs specifically organized for their particular benefit. For this reason, PAC limits will in some circumstances diminish the power of minority candidates."); Conti, supra note 6, at 123-24 ("In short, PACs play a prominent role in the financial security of minority candidates, particularly black candidates, and any restriction on this funding source would disproportionately affect this already underrepresented group."); John Lewis, In Defense of PACs, WASH. POST, July 1, 1994, at A25 (asserting that African American Congressman John Lewis "was able to mount a credible and ultimately successful bid for Congress only because of the support 
These divergent opinions on race and campaign finance reform should not be troubling, as the conflicts reveal the political nature of campaign finance. The diversity of perspectives among those looking to further the interests of people of color is no less legitimate than the varied democratic priorities and values adopted by those who support reform legislation without considering race. ${ }^{253}$ The text of the First Amendment does not embrace a particular political theory as to the mobilization of voters of color, the political strength of people of color in relation to that of large contributors, or the election of particular types of candidates of color in predominantly majority districts and predominantly minority districts. ${ }^{254}$ The disagreements about the effect of campaign finance reform on people of color are based on different assumptions and philosophies about democracy, many of which are reasonable but also inherently political. ${ }^{255}$

given ... by labor union political action committees and a few other PACs"); David J. Weidman, Comment, The Real Truth About Federal Campaign Finance: Rejecting the Hysterical Call for Publicly Financed Congressional Campaigns, 63 TENN. L. REv. 775, 783 (1996) (noting that the Black Congressional Caucus "has vehemently opposed any proposals to eliminate PACs"); Tim Curran, Campaign Finance Reform Bill Besieged By Four Separate Democratic Factions, RoLL CALL, May 17, 1993 (noting that PACs make major contributions to "many African American House Members, who often lack large contributor bases in their own districts"). On the other hand, recognizing that white candidates receive more money from PACs than candidates of color receive, and assuming that very few PACs are financed by or controlled by people of color, large PAC contributions could be said to provide white candidates an advantage over minority candidates and to dilute the influence of voters of color. See TheILMAnN \& WILHITE, supra note 167, at 98-99 (“[B]lack incumbents received $\$ 7,400$ less from labor PACs in 1980, $\$ 16,000$ less from corporate PACs in 1998 , and $\$ 2,800$ to $\$ 4,900$ less from cooperatives' PACs (1982 and 1984)... In 1980, trade PACs gave $\$ 8,300$ less to black candidates, and by 1988 this disparity had almost doubled.").

253. Lowenstein, supra note 149, at 304 ("The problem is that even among those who join in the desire to expunge corrupt campaign finance practices, there is not, and never will be, a consensus on how to evaluate the numerous additional foreseeable effects the reforms will have on politics."). Some have observed that Reformers' support of different reform proposals that advance varied values is the primary obstacle to the passage of reform. See, e.g., Marshall, supra note 12, at 375-76 (observing that the various goals of campaign finance reform often conflict, and the "fact that the types of harms to the political process are so varied means that there is little likelihood that a solution could be crafted that addresses all these concerns"). In light of this observation, one could argue that the consideration of an additional factor such as race diminishes the prospects for the successful adoption of a reform proposal. The consideration of race, however, is no less important than, and is a crucial component of, the consideration of other concerns. Reformers cannot overlook context-specific factors like race and expect to successfully implement broad objectives related to equality, inclusion, and representative government.

254. Cf. Lochner v. New York, 198 U.S. 45, 75-76 (1905) (Holmes, J., dissenting) (“[A] constitution is not intended to embody a particular economic theory, whether of paternalism and the organic relation of the citizen to the State or of laissez faire. It is made for people of fundamentally differing views, and the accident of our finding certain opinions natural and familiar or novel and even shocking ought not to conclude our judgment upon the question of whether statutes embodying them conflict with the Constitution of the United States.").

255. Cf. Edward B. Foley, Philosophy, the Constitution, and Campaign Finance, 10 StAN. L. \& POL'Y REV. 23, 30 (1998) ("Furthermore, we now also understand that, because the words of the First Amendment do not preclude egalitarian campaign finance, Congress should be permitted to adopt this position. Otherwise, the elected representatives of the American people would be denied 
For example, commentators who consider race emphasize an assortment of democratic values and goals, such as increasing the competitiveness of elections for candidates of color, ${ }^{256}$ enhancing minority voter turnout, ${ }^{257}$ and enhancing the political influence of people of color relative to contributors. ${ }^{258}$ Some focus on how citizens, candidates, and parties use political money (either to assist or disadvantage minority voters or candidates). ${ }^{259}$ Some concentrate on the source of political money, and note that the political interests of people of color are marginalized due to the attention afforded the political objectives of those who are able to spend and contribute large amounts. Others could assert that enhanced regulation might increase the possibility of selective enforcement of laws against minority contributors and candidates, ${ }^{260}$ or suppress the grassroots political activity of minorities who lack access to expensive professional services to interpret and comply with regulations. ${ }^{261}$

the right to adopt a philosophically plausible position on campaign finance just because the judiciary held a different philosophical perspective.").

256. See Conti, supra note 6, at 100 ("However, the main goal of any real campaign finance reform must be to increase the competitiveness of congressional elections by attempting to level the playing field between incumbents and challengers."); Smith, supra note 6, at 1509 ("More specifically, McCain-Feingold, as recently passed by the United States Senate, does not assist in creating a level playing field for candidates of color.").

257. See Issacharoff, supra note 6, at 1525 (focusing on how black voter turnout may be hampered due to selected campaign finance reform provisions).

258. See Smith, supra note 6, at 1491 (observing that "money harms voters of color by creating for them, in the words of the Voting Rights Act of 1965, 'less opportunity than other members of the electorate to participate in the political process and to elect representatives of their choice."').

259. Compare Conti, supra note 6, at 132 (asserting that soft money is used for minority voter turnout), with Smith, supra note 6, at 1515-16 ("The soft money ads that the Democratic Party ran on behalf of Al Gore largely tracked the issues of the Gore campaign itself ... [which pursued] ... white swing voters to the exclusion of black concerns.... Soft money without a racially transformative ideology ... renders [black voters] mere supplicants in the political process rather than equals to glorified white independents.").

260. See Chen, supra note 74, at 354 (recognizing that "the entire first month of the Senate's hearings on the campaign finance controversy focused exclusively on activities of Asian Pacific Americans and 49 of the first 53 subpoenas were directed against Asian Pacific Americans"); Mark Curriden, Selective Prosecution: Are Black Officials Investigative Targets?, A.B.A. J., Feb. 1992, at 55 ("“ $[\mathrm{M}]$ ore than 14 percent of the public corruption cases over the past five years targeted black officials, who make up less than two percent of the country's elected officials. ... Since 1980, 21 black elected officials have been prosecuted in Alabama alone [and] . . 16 were found not guilty, two pleaded guilty, and three were convicted.... Though less than one-half of one percent of the federal judiciary is black, three of the five U.S. District Court judges indicted in the past decade were black."); Ernie Freda, Washington in Brief, ATLANTA J. \& CONST., July 13, 1995, at B7, 1995 WL 6535801 (describing the Federal Election Commission's $\$ 150,000$ civil fine against the 1988 Jesse Jackson presidential committee as the highest fine of an individual campaign in history); Chen \& Minami, supra note 74, at 364 (discussing the focus of Senate hearings on Asian-Pacific Americans to the exclusion of foreign nationals from non-Asian states who made more significant contributions); Wang, supra note 74, at 330 ("Instead of addressing the systematic problem of money corruption in politics, politicians discovered a fetching distraction: blame the problem on 'Asians' and the unscrupulous 'agents' of communist China.").

261. $C f$. Smith, supra note 6, at 1083 (arguing that campaign finance regulation typically favors "those with the money and sophistication to hire the lawyers, accountants, and lobbyists needed to 
A sophisticated policy analysis of the racial impact of a particular reform involves an initial understanding of how the reform implicates these different individual values. It also requires a balancing of the ways in which the reform advances various values against how the reform hinders those values. For example, the statement that "soft money is bad for people of color because it dilutes the influence of people of color" is, by itself, incomplete. Similarly, the statement that "soft money is good for people of color because it is used for voter mobilization in minority neighborhoods" is deficient. To arrive at an informed judgment about soft money, one must consider both of these factors (along with others, such as the importance of issue advertisements supporting minority candidates financed by soft money), and balance them against one another. Any balancing will involve an empirical assessment of each factor, such as inquiries into the extent to which soft money contributors are given access to political leaders and the percentage of soft money that is spent on voter mobilization. ${ }^{262}$ The balancing will also involve theoretical but personal value judgments, such as whether the minority voter mobilization financed by soft money is more important to one's view of a properly functioning democracy than minority

comply with complex filing requirements" and will "naturally disadvantage newcomers to the political arena, especially those who are themselves less educated or less able to pay for professional services"); 84 Jackson Unit Will Pay Penalty, N.Y. TIMES, Nov. 3, 1987, at D30, LEXIS, Nexis Library, NYT File (describing the $\$ 13,000$ civil penalty against the 1984 Jesse Jackson presidential committee for mistakes which, according to campaign officials, "reflected the technical inexperience of local dedicated grass-roots volunteers").

262. The opinions about how a ban on soft money and other reforms will uniquely impact people of color may stem, in part, from empirical assumptions that particular ethnic groups are more cohesive in their political preferences than particular economic classes, and that a political party has incentives to raise and spend political money to mobilize members of ethnic groups that are inclined to favor the party. $C f$. MiChaEl Dawson, Behind the Mule: RaCE AND Class in AfRiCAN AMERICAN POLITICS 8 (1994) (“[B]ecause the social, economic, and political realities of whites and blacks differ substantially because of race, racial interests continue to override class interests (whether individual or family).... As long as this is true ... one should expect high levels of political unity among African Americans regardless of economic status.”); ANDREA Y. SIMPSON, The TiE THAT Binds: IDENTITY AND Political ATtitudes IN THE Post-Civil Rights GENERATION 16 (1998) ("[R]egardless of socioeconomic status, age, or gender, blacks believe that their individual fate is tied to the fate of the group."); DONALD KINDER \& LYNN SANDERS, DIVIDED BY COLOR: RACIAL POLITICS AND DEMOCRATIC IDEALS 31 (1996) ("Blacks and whites are socially diverse; they are subject to various crosscutting pressure-but this is not enough, evidently, to prevent race from emerging as a 'single profound line of cleavage."'); see also JENNIFER HOCHSCHILD, FACING UP THE AMERICAN DREAM: RACE, CLASS, AND THE SOUL OF THE NATION 68 (1995) ("Whites believe it [the American dream] works for everyone; blacks believe it works only for those not of their race. Whites are angry that blacks refuse to see the fairness and openness of the system; blacks are angry that whites refuse to see the biases and blockages of the system.”); BILL HING, TO BE AN AMERICAN 173 (1997) (asserting that ethnic identity supports individual political development because many "people of color are isolated or have no sense of identity ... a at work, at school, or in social settings"). 
participation in party politics undiluted by the influence of large soft money contributors. ${ }^{263}$

A consideration of the racial impact of a campaign finance reform proposal is further complicated by context-specific factors. Just as the Bipartisan Campaign Reform Act increases the amount of money an individual can give to a federal candidate to $\$ 2000$ from $\$ 1000$ while also banning unlimited soft money contributions to political parties, ${ }^{264}$ campaign finance legislation often contains multiple provisions that impact people of color in different ways. The effects of these multiple reform provisions must be balanced against one another. Also, individuals of color have varied experiences. An individual minority candidate or voter might look to how the reform proposal impacts her own individual political influence or the influence of her particular ethnic group, and give that impact great weight even though other minority candidates and voters may be impacted in different ways. $^{265}$ Further, various decisionmakers will have different descriptive understandings of how politics actually works and different normative aspirations as to how politics should work. ${ }^{266}$ Although the responsiveness of candidates and parties to the concerns of minority constituents, the success of minority candidates, and the mobilization of minority voters are important factors, no universally accepted baseline or single neutral value exists to use in measuring the racial impact of a particular reform. In analyzing proposed reforms, therefore, those considering race must make judgments as to which democratic values should have priority.

The fact that a ban on soft money and other reforms are far from adequate to address the structural problems that exclude people of color from

263. Cf. Strauss, supra note 39, at 1379-80 ("Part of the task of campaign finance reform is to try to determine what kind of representative government we want-which aspects of representative government we want to suppress, which we want to encourage, and at what cost."). Along similar lines, both the freedom to make out-of-district contributions and the proposal to ban out-of-district contributions may simultaneously benefit and disadvantage people of color. The choice between the two options depends in part on empirical questions that weigh the number of predominantly minority districts against the number of minority candidates from districts with predominantly white populations. A choice between the two options might also involve a political decision that compares the political importance of minority candidates who are accountable to minority constituents against the political importance of minority representatives elected from majority districts.

264. See Bipartisan Campaign Reform Act of 2002, Pub. L. No. 107-155, § 101, 116 Stat. 81 (2002) (banning soft money); $i d . \S 307$ (doubling the amount of money an individual can contribute to a federal candidate from $\$ 1000$ to $\$ 2000)$.

265. Cf. Lowenstein, supra note 149, at 336 ("An issue like campaign finance reform can and should be considered on many levels, including the broadest public interest level but not excluding particularistic interests. The answer to the question of how to talk about campaign finance reform is that it depends on whom you are talking to.").

266. $C f$. id. at 340 ("However, outside the bounds of the minimal consensus, there is no reason to expect one person's conception of the public good to correspond to another's. Plainly, differing conceptions of the public interest come into conflict in the debate on campaign finance."). 
the political process may also contribute to the lack of unanimity regarding campaign finance proposals among those who consider race. A more inclusive vision of democracy might not be confined to choosing between eliminating the political influence of soft money contributors or continuing voter-mobilization efforts in communities of color. ${ }^{267}$ Many who have considered campaign finance proposals and race favor the public financing of elections, which could achieve both objectives. ${ }^{268}$

Whereas questions related to administrability and political feasibility haunt the payment of reparations to people of color, public financing may be a race-neutral solution that mitigates historical disparities in resources with regard to politics. Indeed, public financing illustrates that a consideration of race can serve as a diagnostic tool that exposes broad structural faults in democracy and arrives at solutions that benefit Americans of all ethnic

267. Rather than simply accepting that an individual citizen has a responsibility to secure or meet the conditions necessary for her political participation, an inclusive vision proposes that courts and democratic decisionmakers have a responsibility to create an environment that allows for, and even encourages, participation by all citizens. See Spencer Overton, A Place at the Table, Bush v. Gore Through the Lens of Race, 29 FLA. ST. L. REV. 469 (2001).

268. See Mary Becker, Patriarchy and Inequality: Towards a Substantive Feminism, 1999 U. CHI. Legal F. 21, 60 (drawing the conclusion that "[w]omen, African Americans, Latinos and other disproportionately poor groups near the bottom of the social structure have less political power in an electoral system in which voice and power can be purchased than they would in a system with public financing of campaigns, stringent spending limits, and free media time"); Conti, supra note 6, at 156 ("To enact real reform, to truly give minorities and women the chance to reach parity in the United States Congress, full public financing needs to be enacted."); Smith, supra note 6, at 1522 ("There is arguably no short-term solution to [racial disparities in economic resources] other than a system of public financing or public subsidies to poorer candidates. Inclusionary reform will perhaps have to embrace such a scheme, whatever its imperfections."); NAACP Endorses Public Financing of Elections, Press Release, The Fannie Lou Hamer Project, July 11, 2001, at http://home.att.net/ sodafam/fannielou/naacpend.htm (reporting that in July 2001, the NAACP adopted a resolution calling for full public financing of elections); The Freedom Agenda of The Black Radical Congress, Art. II (1999), at http://blackradicalcongress.com/brc_fagenda.html ("We oppose private financing of electoral campaigns, especially corporate contributions; we will work to replace the present corrupt system with public financing."); H.R. 1637, 107th Cong. (2001) (indicating that the co-sponsors of the public-financing bill included Congressional Hispanic Caucus member Ciro D. Rodriguez and Congressional Black Caucus members William Lacy Clay, John Conyers, Danny Davis, Chaka Fattah, Harold Ford, Jr., Jesse L. Jackson, Barbara Lee, John Lewis, and Cynthia McKinney). Congressional Black Caucus member Harold Ford endorses public financing, although he does not explicitly consider race in his article on campaign finance reform. See Harold E. Ford, Jr. \& Jason M. Levien, A New Horizon for Campaign Finance Reform, 37 HARV. J. ON LEGIS. 307, 317 (2001) ("The most comprehensive campaign finance reform efforts on the federal level ought to include the public financing of congressional elections."). Recognizing the political nature of campaign finance, a few individuals use race to illustrate their objections to public financing. See David A. Mittell, Jr., Bay State's 'Clean Elections' Brouhaha, PROVIDENCE JOURNAL-BULlETiN, Apr. 30, 2000, at 10E ("With public financing, sooner or later the government will be funding the Ku Klux Klan or its like.”); Richard C. Paddock, Prop. 68 Foes Use Klan to Push Message, L.A. TIMES, June 4, 1988, at A27 ("Opponents of [a partial public funding ballot initiative] began a last-minute television campaign Friday with a commercial featuring white-robed 'members' of the Ku Klux Klan who, an announcer in the ad says, could receive tax dollars under the campaign finance initiative."). 
backgrounds. ${ }^{269}$ The plight of those most vulnerable in society, such as people of color who have been adversely impacted by past discriminatory policies, illustrates problems that affect citizens generally when democratic institutions adopt the values and the flaws of private economic markets. ${ }^{270}$ While public financing of campaigns might benefit people of color disproportionately, the reform also benefits Americans generally, as $93 \%$ of the population does not make reportable contributions under the current privately financed system. ${ }^{271}$ By improving "the situation of the less favored" through public financing, decisionmakers "improve that of citizens generally.,272

A democratic vision tailored toward mitigating racial disparities in wealth among citizens might prefer public-financing proposals that allow individual citizens to allocate a fixed amount of public funds to their preferred candidates and severely limit or prohibit the use of private contributions and expenditures to fund election-related speech. ${ }^{273}$ While

269. Some commentators have suggested that there is social utility in heeding and curing the social ills that impact people of color, as these conditions often reflect structural inequities that adversely affect other Americans in less visible ways. See LANI GUINIER \& GERALD TORRES, THE MINER'S CANARY (forthcoming 2002) (“Those who are racially marginalized are like the miner's canary. It is easy enough to think that when we sacrifice this canary the only harm is to communities of color. Yet if those who are racially marginalized do function as the miner's canary, others ignore problems that converge around racial minorities at their own peril. We are ignoring the symptoms that tell us we are all being poisoned."); Minow, supra note 8, at 678 (asserting that "legislatures, police departments, prosecutors, governors, and mayors should examine massive group disparities in their purview as clues to underlying problems deserving remedy").

270. Others have written about considering the perspectives of those most vulnerable when designing institutional structures. $C f$. BELL HOOKS, FEMINIST THEORY FROM MARGIN TO CENTER, at xvi (2d ed. 2000) (asserting that a view from the "margin" allows one to understand both the center and the margin of society, and provides a sense of wholeness); Charles R. Lawrence III, Two Views of the River: A Critique of the Liberal Defense of Affirmative Action, 101 COLUM. L. REV. 928, 950-51 (2001) ("Critics of liberal theory, including critical race theorists, have offered another way to think about promoting equality and human dignity, one that reflects the perspective of the subordinated."); Spencer Overton, Fannie Lou Hamer Wouldn't Like This, L.A. TIMES, Mar. 29, 2001, at B11 (discussing the Fannie Lou Hamer standard, which considers the campaign finance system from the perspective of a poor woman of color like Fannie Lou Hamer).

271. Raskin \& Bonifaz, Constitutional Imperative, supra note 37, at 1177 ("Less than one percent of the nation's population contributed seventy-seven percent of all campaign funds raised in the 1992 election cycle in individual contributions of $\$ 200$ or more.”); Rosenkranz, supra note 182, at 888 (noting that only $4 \%$ to $6 \%$ of Americans make any campaign contributions at all).

272. JOHN RAWLS, A THEORY OF JUSTICE 71 (rev. ed. 1999) (observing that it "seems probable that if the authority and powers of legislators and judges, say, improve the situation of the less favored, they improve that of citizens generally"); Guinier, supra note 8, at 137 ("Thus, the legal claims of racial minorities are not resolved to benefit racial minorities alone but to make politics better for everyone."). Further, the use of racial history in support of public-financing reforms that will benefit most Americans may be a useful step toward persuading most Americans to recognize racial history in support of remedial proposals targeted to help people of color specifically.

273. See Bruce Ackerman, Crediting the Voters: A New Beginning for Campaign Finance, 13 AM. Prospect 71, 78-79 (1993); Foley, supra note 36, at 1204 ("The Constitution of the United States should contain a principle, which I shall call 'equal-dollars-per-voter,' that would guarantee to each eligible voter equal financial resources for purposes of supporting or opposing any candidate 
public-financing plans that give money directly to campaigns allow the candidates to shape the debate, a proposal that allows citizens to allocate funds might better promote their influence and their exercise of associational freedoms. ${ }^{274}$ Employing a process similar to cumulative voting, ${ }^{275}$ citizens of color could strategically concentrate resources behind one candidate or issue that is particularly important to them, ${ }^{276}$ or spread resources out among a variety of candidates or issues. Legislators from predominantly white communities would have greater incentives to consider the claims of those in predominantly minority communities. ${ }^{277}$ Granted, scenarios exist in which direct government allocation of public funds to candidates would seem preferable, such as when a candidate of color has difficulty collecting funds from a predominantly white population. On the whole, however, a system that allows voters to allocate funds might be better because it empowers

or initiative on the ballot in any election held within the United States."); Hasen, supra note 39, at 20-27 (arguing for a voucher system of campaign finance reform). Hasen describes his plan as:

[A] new system of campaign finance that should appeal to those on the left and the right: a plan for mandatory campaign finance vouchers that supplants, rather than supplements, our current campaign finance system. Under this plan, each voter would have the opportunity to contribute vouchers to candidates or to interest groups in every federal election cycle. The interest groups would use the vouchers to contribute to candidates or to organize independent expenditure campaigns. With limited exceptions, only funds from the voucher system could be spent to support or oppose candidates for elected federal offices.

Id. at 5 .

274. Cf. Hasen, supra note 39, at 46-47 ("Indeed, all direct public financing plans, whether level-up or level-down, fail to facilitate the representation of the poor and unorganized. These plans tend to insulate candidates from the political influence of all groups.... Direct public financing will not encourage politicians to seek out the support of underrepresented groups... . Those groups with greater organizational ability, particularly groups which can get out the vote, will fare best. Politics under a public financing regime, then, would look very much like the politics of today.").

275. See LANi GUINIER, ThE TyRANNY OF THE MAJORITY: FundAMENTAL FAIRNESS IN REPRESENTATIVE DEMOCRACY 149 (1994) (noting that politically cohesive minority groups may achieve better representation under a system in which "each voter is given the same number of votes as open seats, and the voter may plump or cumulate her votes to reflect the intensity of her preferences").

276. See Hasen, supra note 39, at 35 ("Another significant advantage of the voucher plan as an intensity-registering mechanism is that it allows people with strong feelings about particular issues to 'plump' all of their support behind a single group or candidate, thereby having greater impact on that issue.").

277. In a similar spirit, Professor Ford would open local elections so that voting is not limited on the basis of municipal residence. See Ford, supra note 84, at 1909-10 ("[Local elections should] not be limited on the basis of residence, but instead would be open to all members of a metropolitan region.... [V]oters would receive a number of votes equal to the number of open seats, which they could cast in any election they wished. Hence voters would effectively draw their own jurisdictional boundaries, decide which local governments were most important to them, and allocate their votes accordingly."). One could argue that campaign finance contributions give Americans the opportunity to congregate with one another. Geography, especially in an age of desegregation, is an insufficient political grouping, and contributions allow individuals with similar perspectives to associate with one another. The current privately financed system limits this form of association to a population that is overwhelmingly white and male. Allowing for citizen allocation of public funds to particular candidates would extend this same freedom to all Americans. 
citizens of color, as well as other Americans, with the opportunities to give contributions currently enjoyed by wealthy contributors. Rather than relying on government to assign public funds to groups and candidates, such a system might better allow people of color and other citizens to identify themselves with groups, movements, or candidates. ${ }^{278}$

Note however, that even with a public-financing program that limits private contributions and expenditures, those who have benefited from past discrimination would still have disproportionate influence over the political process. For example, wealthier whites would still disproportionately own and control newspapers and television news operations that cover and explicitly endorse candidates. ${ }^{279}$ Further, those who have profited from past discrimination could still purchase airtime to promote general political issues and would still own and control most recording companies and movie studios, factors which allow for disproportionate influence over public opinion and which could impact election results. ${ }^{280}$ The relevant question, however, is not whether a regulatory scheme is completely impenetrable, but whether it provides a barrier that is sufficiently great to reduce the number of

278. See Minow, supra note 8 , at $683,683-87$ (observing that "one of the problems behind identity politics is the assignment of individuals by government or powerful actors to groups beyond their own control or choice," and proposing that an "alternative worth exploring is governmental structures that permit people to identify themselves in temporary groups for specific purposes"); $c f$. Foley, supra note 36, at 1255 (“As [Bruce] Ackerman observes, 'special-interest' electoral organizations play an important role in this kind of electoral process.... As long as the money that special-interest groups spend on electoral activities is derived entirely from donations from voters (all of whom have equal electoral funds pursuant to the equal-dollars-per-voter principle), there is nothing objectionable about the degree of influence these special-interest groups may have upon candidates.").

279. Cf. Arthur N. Eisenberg, Buckley, Rupert Murdoch, and the Pursuit of Equality in the Conduct of Elections, 1996 ANN. SURV. AM. L. 451, 460 ("Once you allow Rupert Murdoch to spend as much as he chooses to support or oppose candidates . . the entire regime of spending limits begins to unravel."); Joel Gora, Campaign Finance Reform: Still Searching for a Better Way, 6 J.L. \& POL'Y 137, 153 (1997) ("Why can Rupert Murdoch 'drown out' Ruth Messinger, but George Soros is not permitted to help her out?"); L.A. Powe, Jr., Mass Speech and the Newer First Amendment, 1982 SUP. CT. REV. 243, 267-68 (observing that newspapers and television stations are specifically excluded from the limits on expenditures made on behalf of candidates that accept public funding, and thus the limits are underinclusive because wealthy media owners can reach many voters, but others will not be able to band together for the same purpose).

280. Courts should not necessarily solve this problem by deferring to regulation of the media and money that is spent on expression that shapes public opinion and indirectly impacts election outcomes. First of all, there may be good reasons not to allow regulation of these other activities, as articulated in subpart IV(C). Second, regardless of where one draws the line between activities that can and cannot be regulated, difficult border cases are likely to exist in which individuals engage in unregulated activities to circumvent regulation. Cf. Baker, supra note 203, at 48 ("Under any conception of elections, line drawing will be necessary. Theory can only identify important considerations. It cannot give complete guidance for this pragmatic task. Even if theory specifies an acceptable rationale for putting items on one or the other side of the line, difficult cases are inevitable."). 
attempts at circumvention to justify the cost of the regulation. ${ }^{281}$ Despite the ability of a few to circumvent the public-financing proposal described above, it is likely that noncompliance would be sufficiently uncommon to at least reduce the effects of racial disparities in wealth on political participation.

\section{The "Colorblind Card"}

Some might assert that a racial analysis of campaign finance runs against the Court's increasingly "colorblind" approach to the law. Those who oppose the consideration of race as a legitimate analytical tool might argue that judges applying the "colorblind" principle in equal-protection jurisprudence would strictly scrutinize all race-based decisions, regardless of whether they benefit whites or communities of color. ${ }^{282}$ Strict scrutiny likely applies, the argument goes, even to a decision that is racially neutral in form but enacted in light of implications for racial minorities. ${ }^{283}$ Opponents might distinguish the consideration of race from economic and class-based considerations that implicate minimal judicial scrutiny. ${ }^{284}$

The Supreme Court, however, has never stated that legislatures should not consider the racial implications of a particular measure. While the Court has stated that race should not be the "predominant" factor in a governmental

281. See Pildes \& Schauer, supra note 215 , at 1830 ("The measure of a lock is not the bipolar question of whether it is successful by keeping out everyone or unsuccessful by keeping out no one, but rather the scalar question of whether the barrier is sufficiently great, or the cost sufficiently high, to reduce the number of transgressions by enough to justify the cost of the barrier.").

282. See Adarand Constructors, Inc. v. Pena, 515 U.S. 200, 227 (1995) (holding that strict scrutiny will be applied to all racial classifications regardless of the race of those burdened or benefited); City of Richmond v. J.A. Croson Co., 488 U.S. 469, 506-08 (1989) (plurality opinion) (striking down a municipal plan for race-based minority set-asides of city construction contracts in part because the plan was not "narrowly tailored to remedy the effects of prior discrimination").

283. Justice Scalia has urged the Court to embrace a more stringent color-blindness concept that would prohibit all race-conscious measures apart from remedies for identified victims of discrimination. See Adarand, 515 U.S. at 239 (Scalia, J., concurring in part and in judgment); J.A. Croson Co., 488 U.S. at 526 (Scalia, J., concurring); $c f$. Brown v. North Carolina, 479 U.S. 940, 941 (1986) (O’Connor, J., concurring in denial of certiorari) (“[T]his Nation's profound commitment to the ideal of racial equality ... refuses to permit the State to act on the premise that racial differences matter.").

284. Richard D. Kahlenberg, Getting Beyond Racial Preferences: The Class-Based Compromise, 45 AM. U. L. REV. 721, 724-25 (1996) ("Those wedded to racial preferences on the merits need to explore the class preference alternative as a matter of legal and political necessity.... [I]nstances of racial classifications surviving strict scrutiny are extremely rare. By contrast, 'class' preferences are constitutionally unassailable."); Richard A. Posner, The DeFunis Case and the Constitutionality of Preferential Treatment of Racial Minorities, 1974 SUP. CT. REV. 1, 32 ("[T] he impact of eliminating racial preference is easily exaggerated. The preferred groups [who would benefit from affirmative action] could be redefined as the underprivileged, the deprived, etc.-classifications not based upon race or ethnic origin. The constitutional objection to preferential treatment would thereby be removed, without substantial impairment of the purposes of such treatment."); J.A. Croson Co., 488 U.S. at 509 (observing that "the city has at its disposal a whole array of race-neutral devices to increase the accessibility of city contracting opportunities to small entrepreneurs of all races"). 
decision, it has been careful to note that this guideline does not mean that government can never take race into account. ${ }^{285}$ Unfortunately, perhaps the most significant problem with the emerging "colorblind" jurisprudence is that it has a chilling effect on the consideration of racial implications of facially race-neutral laws. The Court, however, has recognized the importance of the consideration of race in the construction of political processes in its jurisprudence interpreting the Voting Rights Act. ${ }^{286}$

Some might argue that, even if the consideration of race is constitutionally permissible, the best way to eliminate racial disparities is by creating a colorblind state. ${ }^{287}$ Explicit racial considerations cause symbolic or expressive harms ${ }^{288}$ the argument goes, and simply entrench Balkanized politics. ${ }^{289}$ A race-conscious state, one might assert, undermines the possibility of the eventual transformation of America into a "colorblind" society by encouraging private individuals and institutions to think in racial terms. ${ }^{290}$

285. See Easley v. Cromartie, 532 U.S. 234, 242 (2001) (noting that judicial deference to a district drawn by the political branches may be appropriate in situations in which "the voting population is one in which race and political affiliation are highly correlated"); Shaw v. Reno, 509 U.S. 630, 642 (1993) ("This Court has never held that race-conscious state decisionmaking is impermissible in all circumstances."); Kathleen M. Sullivan, After Affirmative Action, 59 OHIO ST. L.J. 1039, 1049 (1998) (observing that "while holding that it is impermissible to disadvantage a person on the basis of race, the Court has never said that it is impermissible to take race into account in government policymaking").

286. See Bush v. Vera, 517 U.S. 952, 958 (1996) ("Strict scrutiny does not apply merely because redistricting is performed with consciousness of race. . . Nor does it apply to all cases of intentional creation of majority-minority districts.”); Miller v. Johnson, 515 U.S. 900, 916 (1995) ("Redistricting legislatures will . . . almost always be aware of racial demographics; but it does not follow that race predominates in the redistricting process."). One might note that the Voting Rights Act is unique in that courts have acknowledged that legislatures may use demographic data such as age, race, and political affiliation when drawing voting district. But, as asserted previously, campaign finance rules are no less important than district lines in shaping the racial distribution of political power; legislatures should be free in both situations to consider the context-specific obstacles that operate to exclude people of color from the political process.

287. See William Van Alstyne, Rites of Passage: Race, the Supreme Court, and the Constitution, 46 U. CHI. L. REV. 775, 809 (1979) (“[W]e shall not see racism disappear by employing its own ways of classifying people and of measuring their rights," and asserting that "one gets beyond racism by getting beyond it now: by a complete, resolute, and credible commitment never to tolerate . . . the differential treatment of other human beings by race.").

288. See Shaw, 509 U.S. at 657 ("Racial classifications of any sort pose the risk of lasting harm to our society. They reinforce the belief, held by too many for too much of our history, that individuals should be judged by the color of their skin.”); Brown, 479 U.S. at 941-42 (O'Connor, J., concurring in denial of certiorari) ("That the Court will not tolerate prosecutors' racially discriminatory use of the peremptory challenge, in effect, is a special rule of relevance, a statement about what this Nation stands for, rather than a statement of fact."); Elizabeth S. Anderson \& Richard H. Pildes, Expressive Theories of Law: A General Restatement, 148 U. PA. L. REV. 1503, 1520 (2000) ("On the rights and equality side of constitutional law, [expressive] theories assert that state action is required to express the appropriate attitudes toward persons.").

289. See Shaw, 509 U.S. at 657 ("Racial gerrymandering, even for remedial purposes, may balkanize us into competing racial factions; it threatens to carry us further from the goal of a political system in which race no longer matters.").

290. See id. at 648 (asserting that "a racial gerrymander may exacerbate the very patterns of racial bloc voting that majority-minority [legislative] districting is sometimes said to counteract"). 
Once race consciousness is morally promoted as a social or legal norm, it becomes more difficult to disavow.

A racial analysis, however, is not equivalent to what some would describe as "playing the race card." A consideration of race is not a rigid rule which, when employed, trumps all other considerations. In contrast, those who play the "colorblind card" mechanically and irrationally silence discussion of relevant issues. Indeed, the seemingly neutral argument against recognizing race is likely to suppress the concerns of racial minorities and prevent change. ${ }^{291}$

Granted, American history is often painful. We cannot live in the past, and sometimes it may seem best to forget some incidents. But lawmaking and the interpretation of law are sufficiently important to warrant that judges and legislators rise to the task of making decisions in light of history. ${ }^{292}$ By focusing on whether a decision tends to reaffirm or exacerbate past discrimination, a consideration of race keeps America's unique history at the forefront of the equation and ensures that important decisions are made in the proper context.

\section{Conclusion}

The consideration of political realities related to race moves the campaign finance debate toward improved jurisprudence and toward more inclusive reforms in a number of ways. First, a racial framework makes critiques of current jurisprudence more salient and powerful. While Reformers highlight the unfairness of politics based on uneven distributions of property, they fail to question the legitimacy of those distributions. A privately financed campaign system that adopts the existing property entitlements as a baseline of political power resuscitates and exacerbates the effects of past discriminatory laws. The current campaign finance system's reinforcement of racial hierarchies that arose from deliberate state-sponsored discrimination is at least as troubling as the system's reinforcement of classbased hierarchies.

Second, the lens of race exposes the Reformers' oversight of historical realities related to racial exclusion from the political process, a pressing

291. See Iris MARION Young, JustiCE AND the Politics of DifFEREnCE 9 (1990) (“[S]ome philosophers and policymakers even refuse to acknowledge the reality of social groups, a denial that often reinforces group oppressions."); Jerome McCristal Culp, Jr., The Woody Allen Blues: “Identity Politics," Race, and the Law, 51 FLA. L. REV. 511, 523 (1999) ("Ultimately, these attacks on the identity of those who are seeking political change about what is fair and equal is an effort to prevent change.").

292. Cf. Vikram David Amar \& Alan Brownstein, The Hybrid Nature of Political Rights, 50 StAN. L. REV. 915, 1013 (1998) (observing that "the Court will never face any of these difficult questions if it pretermits consideration of such issues with the simplistic invocation of the individualistic equality mandated by indiscriminate application of the Court's color-blind vision"). 
problem in American democracy. While important correlations between race and class exist, the two are not synonymous, and some reform proposals contain provisions that can be said to hamper efforts to include people of color in the political process. The reform project will never succeed in addressing its concerns regarding the quality of campaign discourse, legitimacy of government, and widespread participation in democracy if it ignores the context-specific costs and benefits of its reform proposals. In order to solidify their claims within the historical and contemporary realities of politics, Reformers must engage in a more sophisticated analysis and craft reforms that promote meaningful and effective participation for all Americans, including people of color.

Finally, a racial analysis reveals that campaign finance may provide an additional tool to help diminish racial disparities in society generally. A more equitable democratic environment allows people of color to use the political process to secure privileges and resources for themselves. ${ }^{293}$ Some facially race-neutral campaign finance reforms crafted after a consideration of race may enhance the ability of people of color to improve their conditions through participation in the political process. These reforms may be less vulnerable to criticisms articulated against affirmative action, reparations, race-based redistricting, and other race-specific remedial devices.

Campaign finance reform that diminishes the political disadvantages currently faced by people of color supplies an important step toward improving democratic dialogue and redressing racial harms. A more comprehensive understanding of campaign finance requires the integration of race as an important analytical consideration.

293. Cf. Wesberry v. Sanders, 376 U.S. 1, 17 (1964) ("No right is more precious in a free country than that of having a voice in the election of those who make the laws under which, as good citizens, we must live.”); Yick Wo v. Hopkins, 118 U.S. 356, 370 (1886) (noting that the political franchise "is regarded as a fundamental political right, because [it is] preservative of all rights"). 